Estudios Constitucionales, Año 10, No 2, 2012, pp. 57 - 140.

ISSN 0718-0195

Centro de Estudios Constitucionales de Chile Universidad de Talca

"Diálogo interjurisdiccional, control de convencionalidad y jurisprudencia del

Tribunal Constitucional en período 2006-2011"

Humberto Nogueira Alcalá

\title{
DIÁLOGO INTERJURISDICCIONAL, CONTROL DE CONVENCIONALIDAD Y JURISPRUDENCIA DEL TRIBUNAL CONSTITUCIONAL EN PERÍODO 2006-2011 ${ }^{1}$
}

\author{
INTER-JURISDICTIONAL DIALOGUE, CONTROL OF CONVENTIONALITY \\ AND JURISPRUdENCE OF THE CONSTITUTIONAL COURT IN THE \\ PERIOD 2006-2011
}

\author{
Humberto Nogueira Alcalá \\ Profesor Titular de Derecho Constitucional, \\ Universidad de Talca. \\ nogueira@utalca.cl
}

RESUMEN: En el presente artículo se realiza el análisis de los jueces nacionales como jueces de control de convencionalidad y sus fundamentos jurídicos, como asimismo el tipo posible de diálogo entre las jurisdicciones nacionales con la Corte Interamericana de Derechos Humanos y las modalidades en que se puede concretar dicho diálogo por parte de las judicaturas nacionales, concluyendo con un análisis del uso de la jurisprudencia de la CIDH por parte de las sentencias del Tribunal Constitucional chileno.

ABSTRACT: In this article we performed the analysis of national judges as judges of control of conventionality and its legal basis, as also the type of dialogue between national jurisdictions with the Inter-American Court of Human Rights and the modalities that can specify this dialogue by national judiciaries, concluding with an analysis of the use of the jurisprudence of the IACHR by the Chilean Constitutional Court judgments.

PALABRAS CLAVE: Diálogo interjurisdiccional; control de convencionalidad; corpus iuris interamericano y su impacto en derecho interno.

KEY WORDS: Interjurisdictional dialogue; control of conventionality; inter-American corpus iuris and its impact on domestic law.

\section{INTRODUCCIÓN}

La internacionalización del diálogo de los jueces es la manifestación de la desnacionalización del diálogo. El juez tradicionalmente vinculado a un territorio

\footnotetext{
${ }^{1}$ Este artículo es parte del proyecto de investigación Fondecyt Regular No 1110016-2011 sobre "Análisis de las sentencias del Tribunal Constitucional sobre utilización del derecho constitucional extranjero y del derecho internacional de los derechos humanos y sus implicancias para el parámetro de control de constitucionalidad" del cual el autor es investigador principal. Este trabajo fue presentado en el XIX encuentro de presidentes y Magistrados de Tribunales y salas constitucionales de América Latina "La justicia constitucional ante los retos de la globalización", Viña del Mar, 13 al 15 de noviembre de 2012. Artículo presentado el 19 de junio y aprobado el 11 julio de 2012.
} 
estatal como a procedimientos de derecho interno y a un sistema de normas específicas es inducido a abrirse a otros jueces y a otros universos sistémicos de normas jurídicas

La noción de "apertura" permite considerar el amplio conjunto de manifestaciones de la internacionalización del derecho como tal, concretando un diálogo judicial que se desarrolla en un espacio en que las fronteras nacionales, culturales, lingüísticas retroceden cada día un poco más, ante sistemas jurídicos internacionales y supranacionales.

El diálogo interjudicial constituye un debate, una conversación o intercambio de puntos de vista entre dos o más jueces o tribunales, sean estos nacionales, o producto de una vinculación del Estado a un ordenamiento jurídico y tribunal internacional o supranacional, un diálogo entre tribunales nacionales, como ocurre entre tribunales ordinarios y tribunal constitucional; entre tribunales nacionales e internacionales o supranacionales, como es el caso entre jueces y tribunales nacionales ordinarios o constitucionales con la Corte Interamericana de Derechos Humanos (en adelante CIDH) o en Europa con el Tribunal Europeo de Derechos Humanos ${ }^{2}$, (en adelante TEDH); como asimismo, puede darse como un diálogo entre tribunales internacionales o supranacionales, por ejemplo entre cortes regionales de derechos humanos ${ }^{3}$.

El diálogo induce tanto a la oposición y contradicción, como al acuerdo y la concordia, pudiendo desarrollarse entre una pluralidad de jueces, pudiendo ser bi o multidimensional. El diálogo puede alimentarse de diversas interacciones entre diversos jueces o tribunales.

Un primer tipo de diálogo se desarrolla inserto en el seno de un sistema jurídico en que el Estado es parte de un ordenamiento internacional o supranacional al que se vincula y tiene el aspecto de verticalidad en la medida que toma cuerpo entre un juez interno y un juez internacional, siendo este último el cual tiene la última palabra en las materias en que el Estado parte se ha sometido a su jurisdicción vinculante, en el ámbito de su competencia. La participación de los estados como partes de ordenamientos convencionales que aseguran y garantizan derechos humanos establecen restricciones procesales

\footnotetext{
${ }^{2}$ Sobre la materia, pueden verse por ejemplo, BURGORGUE-LARSEN, Laurence. (2009), pp. 95-130. SZYMCZAK, David. (2006). Sudre, Frédéric. (2004). Kampto, Maurice. (2003), pp. 393-460. Nogueira Alcalá, Humberto. (coord.), (2012), 525 pp. GarCía-SAYÁn, Diego. (2005), pp. 323-384.

${ }^{3}$ A modo de ejemplo ver el diálogo entre Tribunal Europeo de Derechos Humanos y Corte Interamericana de Derechos Humanos: García Roca, Javier; Nogueira Alcalá, Humberto y Bustos, Rafael. (2012), pp. 65-107.
} 
específicas en relación a los órdenes jurídicos internos que van a obligar a los jueces domésticos a dialogar necesariamente con los jueces internacionales, como asimismo a coordinar y armonizar la jurisprudencia nacional con la de la Corte Internacional, debiendo asegurar el juez interno al menos el estándar minimo común o "protección equivalente" a la que brinda la jurisprudencia de la Corte Internacional respectiva. Esta es la perspectiva en que desarrolla sus funciones la Corte de San José, conceptos ya desarrollados y aplicados desde hace décadas por la Corte de Estrasburgo respecto de la Convención Europea de Derechos Humanos, siendo dichos tribunales internacionales los que tienen la competencia de intérpretes fidedignos y finales del respectivo ordenamiento jurídico, como en el ámbito europeo ha explicitado con claridad el TEDH, en la sentencia Bosphorus vs. Irlanda ${ }^{4}$, lo que está explicitado en el caso del sistema interamericano para la CIDH, en los artículos 62.3 y 64 de la CADH.

En este ámbito de diálogo vinculado y con cierto carácter vertical, debe tenerse presente las resistencias provocadas por pre-conceptos, pre-juicios y paradigmas mentales, producto de una formación jurídica que no consideró en su momento la apertura de los sistemas jurídicos al derecho y a las judicaturas internacionales y supranacionales, lo que requiere abrirse a la nueva jurídica y la asimilación de ellas por los jueces domésticos, respecto de lo cual el tiempo debe hacer su trabajo con el objeto de que los tribunales y cortes nacionales se acostumbren al derecho integrado y acepten todas las consecuencias procedimentales del mismo, sin perjuicio de la incorporación de estas nuevas perspectivas a los planes de estudio de las Facultades de Derecho, en pre y posgrado y en las escuelas o academias judiciales, las cuales han tenido en la materia una reacción tardía, mientras otras aún ignoran y no dan cuenta del problema ni de la materia.

El segundo espacio de diálogo, el diálogo horizontal libre de todo vínculo jurídico es mucho más abierto, ya que no se concreta a un sistema específico. Aquí los jueces desarrollan diálogos judiciales sobre la base de una apertura espontánea al mundo de la justicia en la globalidad internacional. Los jueces conversan cualquiera sea su sistema de conexión internacional o nacional y su competencia, en muchos casos no existe ninguna relación jurídica, como ocurre en el diálogo entre CIDH y TEDH, o entre tribunales constitucionales y cortes supremas de países de Latinoamérica con el TEDH, o el diálogo entre

\footnotetext{
${ }^{4}$ TEDH. Sentencia Bosphurus Java Jollari Turizm ve Ticaret c/ Irlanda. 30 de junio de 2005, No 45036/98. Ver Gambino, Silvio. (2011), p. 157.
} 
jurisdicciones constitucionales americanas y europeas, para sólo señalar algunos ejemplos.

Ambos sistemas de diálogo, en un caso obligatorio u "orquestado" por la vinculación jurídica de quienes participan producto de ser partes de un sistema jurídico determinado o, en el otro, libre o "desenfrenado", se desarrollan de manera similar.

El diálogo es horizontal, libre, "desbocado" o "desenfrenado" cuando no existe ninguna obligación de efectuarlo, citando jurisprudencias de otras cortes internacionales regionales (Corte Europea de Derechos Humanos) o de otras jurisdicciones extranjeras, dando lugar a un diálogo espontáneo, tanto dentro de ámbitos continentales o en diálogos intercontinentales.

En este artículo analizaremos los diálogos que necesariamente deben concretarse entre las jurisdicciones ordinarias y constitucionales domésticas de los estados partes de la Convención Americana sobre Derechos Humanos (en adelante, $\mathrm{CADH}$ ) con la $\mathrm{CIDH}$, como el diálogo libre con el TEDH, centrando el análisis en el caso chileno y, dentro del mismo, en el Tribunal Constitucional.

Ello nos lleva a considerar (1) Los jueces y jurisdicciones nacionales como jueces interamericanos en aplicación del control de convencionalidad; (2) el juez nacional como juez natural del corpus iuris interamericano, (3) el diálogo de las jurisdicciones nacionales con la CIDH y las distintas modalidades de interpretación desarrolladas por el juez nacional; (4) el fin del diálogo interjurisdiccional entre tribunales nacionales y Corte Interamericana; (5) El impacto del corpus iuris interamericano en el derecho interno. (6) El control de convencionalidad en la praxis del Tribunal Constitucional chileno. (7) Los efectos jurídicos de las sentencias de la $\mathrm{CIDH}$ en el derecho chileno.

\section{LOS JUECES Y JURISDICCIONES NACIONALES COMO JUECES INTERAMERICANOS A TRAVÉS DEL CONTROL DE CONVENCIONALIDAD}

El control de convencionalidad que debe ser desarrollado por los jueces nacionales implica internalizar en su actividad jurisdiccional que son jueces interamericanos en el plano nacional, debiendo siempre garantizar los atributos de los derechos contenidos en la $\mathrm{CADH}$, impidiendo que éstos sean afectados por normas jurídicas de derecho interno o conductas y actos de agentes del Estado que desconozcan los estándares mínimos determinados convencionalmente. 
El concepto de control de convencionalidad fue establecido formalmente por la CIDH, por primera vez, en forma unánime, en la sentencia "Almonacid Arellano y otros vs. Chile", el 26 de septiembre de 2006, señalando que:

“124 .La Corte es consciente que los jueces y tribunales internos están sujetos al imperio de la ley y, por ello, están obligados a aplicar las disposiciones vigentes en el ordenamiento jurídico. Pero cuando un Estado ha ratificado un tratado internacional como la Convención Americana, sus jueces, como parte del aparato del Estado, también están sometidos a ella, lo que les obliga a velar porque los efectos de las disposiciones de la Convención no se vean mermadas por la aplicación de leyes contrarias a su objeto y fin, y que desde un inicio carecen de efectos jurídicos. En otras palabras, el Poder Judicial debe ejercer una especie de 'control de convencionalidad' entre las normas jurídicas internas que aplican en los casos concretos y la Convención Americana sobre Derechos Humanos. En esta tarea, el Poder Judicial debe tener en cuenta no solamente el tratado, sino también la interpretación que del mismo ha hecho la Corte Interamericana, intérprete última de la Convención Americana"s.

La obligación por parte de los jueces nacionales de concretar el control de convencionalidad ha sido reiterada en forma uniforme en diversos fallos de la $\mathrm{CIDH}$, sin mayores variantes ${ }^{6}$, hasta llegar al caso "Trabajadores Cesados del Congreso vs. Perú", donde la CIDH precisó en mejor forma el control de convencionalidad, señalando que:

"128. Cuando un Estado ha ratificado un tratado internacional como la Convención Americana, sus jueces también están sometidos a ella, lo que les obliga a velar porque el efecto útil de la Convención no se vea mermado o anulado por la aplicación de leyes contrarias a sus disposiciones, objeto y fin. En otras palabras, los órganos del Poder Judicial deben ejercer no sólo un control de constitucionalidad, sino también 'de convencionalidad' ex officio entre las normas internas y la Convención Americana, evidentemente en el marco de sus respectivas competencias y de las regulaciones procesales correspondientes" 7 .

\footnotetext{
${ }_{5}^{5}$ Corte IDH. Caso Almonacid Arellano y otros Vs. Chile. Excepciones Preliminares, Fondo, Reparaciones y Costas. Sentencia de 26 de septiembre de 2006. Serie C No 154, párrafo 124.

${ }^{6}$ Los casos "La Cantuta vs. Perú", sentencia del 29 de noviembre de 2006, considerando 173; en el caso "Trabajadores Cesados del Congreso (Aguado Alfaro y otros) vs. Perú", Serie C No 162, del 24 de noviembre de 2006, párrafo 128.

7 Corte IDH. Caso Trabajadores Cesados del Congreso (Aguado Alfaro y otros) Vs. Perú. Excepciones Preliminares, Fondo, Reparaciones y Costas. Sentencia de 24 de Noviembre de 2006. Serie C No 158., párrafo 128.
} 
A su vez, en el Caso Heliodoro Portugal vs. Panamá de 2008, la CIDH precisó:

"180. La Corte ha interpretado que tal adecuación implica la adopción de medidas en dos vertientes, a saber: i) la supresión de las normas y prácticas de cualquier naturaleza que entrañen violación a las garantías previstas en la Convención o que desconozcan los derechos allí reconocidos u obstaculicen su ejercicio, y ii) la expedición de normas y el desarrollo de prácticas conducentes a la efectiva observancia de dichas garantías ${ }^{8}$. Precisamente, respecto a la adopción de dichas medidas, es importante destacar que la defensa u observancia de los derechos humanos a la luz de los compromisos internacionales en cuanto a la labor de los operadores de justicia, debe realizarse a través de lo que se denomina 'control de convencionalidad', según el cual cada juzgador debe velar por el efecto útil de los instrumentos internacionales, de manera que no quede mermado o anulado por la aplicación de normas o prácticas internas contrarias al objeto y fin del instrumento internacional o del estándar internacional de protección de los derechos humanos ${ }^{9{ }^{\prime 10}}$.

En el caso Cabrera García y Montiel Flores vs. México, de 26 de noviembre de $2010^{11}$, la CIDH, introduce nuevas precisiones al control de convencionalidad que deben desarrollar las jurisdicciones nacionales:

"225. Este Tribunal ha establecido en su jurisprudencia que es consciente que las autoridades internas están sujetas al imperio de la ley y, por ello, están obligadas a aplicar las disposiciones vigentes en el ordenamiento jurídico. Pero cuando un Estado es Parte de un tratado internacional como la Convención Americana, todos sus órganos, incluidos sus jueces, también están sometidos a aquél, lo cual les obliga a velar por que los efectos de las disposiciones de la Convención no se vean mermados por la aplicación de normas contrarias a su objeto y fin. Los jueces y órganos vinculados a la administración de justicia en todos los niveles están en la obligación de ejercer ex officio un 'control de convencionalidad' entre las normas in-

${ }^{8}$ Cfr. Caso Castillo Petruzzi y otros, supra nota 17, párr. 207; Caso Almonacid Arellano y otros, supra nota 10, párr. 118, y Caso Salvador Chiriboga, supra nota 6, párr. 122.

9 Cfr. Caso Almonacid Arellano y otros, supra nota 10, párr. 124, y Caso Boyce y otros, supra nota 20, párr. 113 .

${ }^{10}$ Corte IDH. Caso Heliodoro Portugal vs. Panamá. Excepciones Preliminares, Fondo, Reparaciones y Costas. Sentencia de 12 de agosto de 2008, serie C No 186, párrafo 180.

${ }^{11}$ Corte IDH. Caso Cabrera García y Montiel Flores Vs. México. Excepción Preliminar, Fondo, Reparaciones y Costas. Sentencia de 26 de noviembre de 2010. Serie C No 220. 
ternas y la Convención Americana, evidentemente en el marco de sus respectivas competencias y de las regulaciones procesales correspondientes. En esta tarea, los jueces y órganos judiciales vinculados a la administración de justicia deben tener en cuenta no solamente el tratado, sino también la interpretación que del mismo ha hecho la Corte Interamericana, intérprete última de la Convención Americana. (negritas añadidas).

En 2011, en la sentencia del caso Gelman vs. Uruguay, la Corte Interamericana reitera una vez más su jurisprudencia, señalando:

"193. Cuando un Estado es Parte de un tratado internacional como la Convención Americana, todos sus órganos, incluidos sus jueces, están sometidos a aquél, lo cual les obliga a velar por que los efectos de las disposiciones de la Convención no se vean mermados por la aplicación de normas contrarias a su objeto y fin, por lo que los jueces y órganos vinculados a la administración de justicia en todos los niveles están en la obligación de ejercer ex officio un 'control de convencionalidad' entre las normas internas y la Convención Americana, evidentemente en el marco de sus respectivas competencias y de las regulaciones procesales correspondientes y en esta tarea, deben tener en cuenta no solamente el tratado, sino también la interpretación que del mismo ha hecho la Corte Interamericana, intérprete última de la Convención Americana ${ }^{12 " 13}$.

Esta perspectiva se ha reiterado uniformemente en decenas de casos la $\mathrm{CIDH}^{14}$, con el objeto de que dicha obligación de concretar el control de con-

\footnotetext{
${ }^{12}$ Corte IDH. Caso Almonacid Arellano y otros vs. Chile. Excepciones Preliminares, Fondo, Reparaciones y costas. Sentencia de 26 de septiembre de 2006. Serie C No 154, párrafo. 124. Ver también Caso Cabrera García y Montiel Flores, párrafo. 225. Las negritas son nuestras.

${ }^{13}$ Corte IDH. Caso Gelman Vs. Uruguay. Fondo y Reparaciones. Sentencia de 24 de febrero de 2011 Serie C No 221, párrafo 193. Las negritas son nuestras.

${ }_{14}$ Entre ellos, Caso Heliodoro Portugal vs. Panamá. Excepciones Preliminares, Fondo, Reparaciones y Costas. Sentencia de 12 de agosto de 2008, serie C No 186, párrafo 180; Caso Rosendo Radilla Pacheco vs. Estados Unidos Mexicanos. Excepciones Preliminares, Fondo, Reparaciones y Costas. Sentencia de 23 de noviembre de 2009. Serie C No 209, párrafo 339. Caso Manuel Cepeda Vargas vs. Colombia. Excepciones Preliminares, Fondo y Reparaciones. Sentencia de 26 de mayo de 2010. Serie C No 213, párrafo 208, nota 307; Caso Comunidad Indígena Xákmok Kásek vs. Paraguay. Fondo, Reparaciones y Costas. Sentencia de 24 de agosto de 2010. Serie C No 214, párrafo. 311; Caso Fernández Ortega y Otros vs. México. Excepción Preliminar, Fondo, Reparaciones y Costas. Sentencia de 30 de agosto de 2010. Serie C No 215, párrafo 234; Caso Cabrera García y Montiel Flores vs. México. Excepciones Preliminares, Fondo, Reparaciones y Costas. Sentencia de 26 de noviembre de 2010; Caso Gelman Vs. Uruguay. Fondo y Reparaciones. Sentencia de 24 de febrero de 2011 Serie C No 221, párrafo
} 
vencionalidad sea efectivamente desarrollado por las jurisdicciones nacionales, lo que posibilita, asimismo, descargar a la CIDH de un cúmulo de casos que perfectamente pueden ser asumidos por los jueces nacionales por aplicación de la Convención y de la interpretación de sus enunciados normativos sobre derechos que ya han sido interpretados y aplicados por la $\mathrm{CIDH}$, existiendo claras líneas jurisprudenciales de ésta sobre la materia.

El control de convencionalidad llamados a desarrollar los tribunales domésticos, es el que debe ejercer todo juez de un Estado Parte, juez ordinario o constitucional, en aplicación del deber jurídico de respetar y garantizar los derechos convencionales de conformidad con el artículo $1^{\circ}$ de la CADH, y la obligación de aplicar las medidas jurisdiccionales para asegurar la adecuación al sistema interamericano exigida por el artículo $2^{\circ}$ de la misma $\mathrm{CADH}$, aplicando como estándar minimo los atributos de los derechos y garantías contenidos en la CADH y el corpus iuris interamericano, lo que constituye un control diferente y distinto del control de constitucionalidad.

El control de convencionalidad tiene como parámetro de control el corpus iuris interamericano, cuyo texto central y básico es la Convención Americana sobre Derechos Humanos, mientras que el control de constitucionalidad tiene como parámetro básico la Constitución Política de la República. El control de convencionalidad deben concretarlo todos los órganos jurisdiccionales de los Estados Partes, sean estos ordinarios o constitucionales, mientras que el control de constitucionalidad sólo lo pueden concretar los órganos que la respectiva Constitución Política determina, de acuerdo a la distribución de competencias y las formas legales de derecho interno.

El concepto de control de convencionalidad no es un concepto nuevo creado por la CIDH, sino un concepto usado desde hace varias décadas en el sistema europeo de derechos humanos, para explicitar la función que le corresponde a los jueces nacionales de velar por el respeto y garantía de los derechos humanos que como estándar mínimo deben concretar los estados partes del sistema ${ }^{15}$.

193. Caso López Mendoza vs. Venezuela. Sentencia de 1 de septiembre de 2011 (fondo, reparaciones y costas), párrafo 226.

${ }^{15}$ Ver Sudre, F. (2004) “a propos du 'dialogue des juges' et du control de conventionalité”, en Études en l'Honneur de Jean Claude Gautrón. Les dynamiques du doit européen en début du siècle. Ed. A. Pedone, Paris. 


\subsection{Análisis del fundamento normativo positivo del control de convencionalidad}

El control de convencionalidad emana de las dos obligaciones erga omnes que los estados partes asumieron libre y voluntariamente al ratificar la Convención Americana sobre Derechos Humanos, las contenidas en los artículos $1^{\circ}$ y $2^{\circ}$ de ella, por una parte, como asimismo por el reconocimiento, también libre y voluntario, de la jurisdicción vinculante de las sentencias de la Corte Interamericana de Derechos Humanos, las que constituyen obligaciones de resultado para el Estado Parte, de acuerdo a los artículos 67 a 69 de la misma convención, como por último del reconocimiento de la Corte interamericana como intérprete auténtica y final de la $\mathrm{CADH}$.

\subsubsection{La obligación erga omnes de asegurar y garantizar los derechos asegurados por la Convención de forma directa e inmediata (art. $1^{\circ}$ de la CADH)}

El artículo $1^{\circ}$ de la CADH determina para los estados parte la obligación jurídica de respetar y garantizar los derechos asegurados por ella:

"1. Los Estados Partes en esta Convención se comprometen a respetar los derechos y libertades reconocidos en ella y a garantizar su libre y pleno ejercicio a toda persona que esté sujeta a su jurisdicción, sin discriminación alguna por motivos de raza, color, sexo, idioma, religión, opiniones políticas o de cualquier otra índole, origen nacional o social, posición económica, nacimiento o cualquier otra condición social.

2. Para los efectos de esta Convención, persona es todo ser humano".

Las obligaciones contenidas en el derecho convencional internacional, con mayor razón aún si se trata de derechos fundamentales, sobre todo si el Estado es parte de la Convención de Viena sobre Derecho de los Tratados, el cual es parte, además, del derecho interno, constituye para los jueces derecho directamente aplicable y con carácter preferente frente a las normas jurídicas legales internas, ya que el propio ordenamiento jurídico hace suyo los artículos 26 y 31.1, por una parte y el 27 de la Convención, por otra; los primeros determinan la obligación de cumplir de buena fe las obligaciones internacionales (Pacta Sunt Servanda y Bonna Fide), el artículo 27, a su vez, establece el deber de no generar obstáculos de derecho interno al cumplimiento de las obligaciones internacionales. 
En esta materia, la CIDH ha sido extremadamente clara al respecto:

“125. En esta misma línea de ideas, esta Corte ha establecido que "[s]egún el derecho internacional las obligaciones que éste impone deben ser cumplidas de buena fe y no puede invocarse para su incumplimiento el derecho interno" ${ }^{16}$. Esta regla ha sido codificada en el artículo 27 de la Convención de Viena sobre el Derecho de los Tratados de 1969"17.

Asimismo la CIDH en el caso "La última tentación de Cristo" ha precisado que:

"En el derecho de gentes, una norma consuetudinaria prescribe que un Estado que ha ratificado un tratado de derechos humanos debe introducir en su derecho interno las modificaciones necesarias para asegurar el fiel cumplimiento de las obligaciones asumidas. Esta norma es universalmente aceptada, con respaldo jurisprudencial ${ }^{18}{ }^{\prime 19}$.

A su vez, la CIDH, desde el primer caso conocido jurisdiccionalmente, en la sentencia en el caso Velásquez Rodríguez, en forma uniforme y reiterada ha determinado que

"La segunda obligación de los Estados partes es la de 'garantizar' el libre y pleno ejercicio de los derechos reconocidos en la Convención a toda persona sujeta a su jurisdicción. Esta obligación implica el deber de los Estados Partes de organizar todo el aparato gubernamental y, en general, todas las estructuras a través de las cuales se manifiesta el ejercicio del poder público, de manera tal que sean capaces de asegurar jurídicamente el libre y pleno ejercicio de los derechos humanos. Como consecuencia de esta obligación los Estados deben prevenir, investigar y sancionar toda violación de los derechos reconocidos por la Convención y procurar, además, el restablecimiento, si es posible, del derecho conculcado y, en

\footnotetext{
${ }^{16}$ Cfr. Responsabilidad Internacional por Expedición y Aplicación de Leyes Violatorias de la Convención (Arts. 1 y 2 Convención Americana Sobre Derechos Humanos), Opinión Consultiva OC-14/94 del 9 de diciembre de 1994, Serie A No 14, párr. 35.

${ }^{17}$ Corte IDH. Caso Almonacid Arellano y otros Vs. Chile. Excepciones Preliminares, Fondo, Reparaciones y Costas. Sentencia de 26 de septiembre de 2006. Serie C No 154, párrafo 125.

${ }^{18}$ Cfr. "principe allant de soi"; Echange des populations grecques et turques, avis consultatif, 1925, C.P.J.I., série B, No 10, p. 20; y Caso Durand y Ugarte, supra nota 20, párr. 136.

19 Corte IDH. Caso "La Última Tentación de Cristo" (Olmedo Bustos y otros) Vs. Chile. Fondo, Reparaciones y Costas. Sentencia de 5 de febrero de 2001. Serie C No 73, párrafo 87.
} 
su caso, la reparación de los daños producidos por la violación de los derechos humanos" ${ }^{20}$.

Finalmente, la CIDH ha precisado que la obligación de garantizar los derechos asegurados en la Convención:

“(...) no se agota con la existencia de un orden normativo dirigido a hacer posible el cumplimiento de esta obligación, sino que comporta la necesidad de una conducta gubernamental que asegure la existencia, en la realidad, de una eficaz garantía del libre y pleno ejercicio de los derechos humanos" 21 .

\subsubsection{La obligación de los estados partes de adecuar su ordenamiento jurídico y la actuación de sus órganos al cumplimiento con las obligaciones de respeto y garantía de los derechos (Art. $2^{\circ}$ de la CADH)}

El artículo $2^{\circ}$ de la $C A D H$ establece el deber de adoptar disposiciones de derecho interno por los estados partes de ella, en sus expresiones:

"Si el ejercicio de los derechos y libertades mencionados en el artículo $1^{\circ}$ no estuviere ya garantizado por disposiciones legislativas o de otro carácter, los Estados Partes se comprometen a adoptar, con arreglo a sus procedimientos constitucionales y a las disposiciones de esta Convención, las medidas legislativas o de otro carácter que fueren necesarias para hacer efectivos tales derechos y libertades".

La CADH establece la obligación general de cada Estado Parte de adecuar su derecho interno a las disposiciones de dicha Convención, para garantizar los derechos en ella consagrados. Ello significa que el Estado debe adoptar todas las medidas para que lo establecido en la Convención sea efectivamente cumplido en su ordenamiento jurídico interno, tal como lo determina el artículo $2^{\circ}$ de la Convención. Dicho deber general del Estado Parte implica que las medidas de derecho interno han de ser efectivas (principio del effet utile). Dichas medidas sólo son efectivas cuando el Estado adapta su actuación a la normativa de

\footnotetext{
${ }^{20}$ Corte IDH. Caso Velásquez Rodríguez Vs. Honduras. Fondo. Sentencia de 29 de julio de 1988. Serie C No 4, párrafo 166. La Corte se había pronunciado previamente respecto de excepciones preliminares en Sentencia de 26 de junio de 1987, Serie C No 1.

${ }^{21}$ Corte IDH. Caso de la Masacre de Pueblo Bello Vs. Colombia. Fondo, Reparaciones y Costas. Sentencia de 31 de enero de 2006. Serie C No 140, párrafo 142.
} 
protección y garantía de los derechos asegurados por la Convención, como ha precisado la $\mathrm{CIDH}$ en su jurisprudencia ${ }^{22}$.

Por otra parte, es necesario referirse a la obligación general de los Estados Partes contenida en el artículo $2^{\circ}$ de la $\mathrm{CADH}$, de "adoptar, con arreglo a sus procedimientos constitucionales y a las disposiciones de esta Convención, las medidas legislativas o de otro carácter que fueren necesarias para hacer efectivos tales derechos y libertades".

La adopción de medidas legislativas que la $\mathrm{CADH}$ establece como deber del Estado cuando no se encuentran debidamente asegurados y garantizados los derechos convencionales, implica el deber estatal de adoptar las medidas jurídicas que adecuen el derecho interno, desde el texto constitucional hasta la última disposición administrativa, de manera que el ordenamiento jurídico del Estado Parte asegure y garantice los atributos que integran los respectivos derechos convencionales y sus garantías, en los estándares mínimos determinados por la CADH. Sobre dichos estándares los estados partes son libres para asegurar y garantizar al Estado mayores atributos y garantías de los derechos que los establecidos convencionalmente o asumir la garantía de otros derechos considerados como fundamentales o esenciales.

El Estado Parte de la CADH debe eliminar de su ordenamiento jurídico y está impedido de crear o generar leyes u otras normas jurídicas que vulneren los derechos asegurados convencionalmente ${ }^{23}$.

A su vez, los estados partes de la CADH deben abstenerse de emitir a través de sus órganos jurisdiccionales resoluciones judiciales que constituyan actos arbitrarios o írritos que vulneren derechos humanos, los cuales carecen desde un principio de valor y eficacia jurídica, como ha ocurrido en el caso "Palamara Iribarne vs. Chile" ${ }^{24}$, como asimismo, en el caso "Almonacid Arellano vs. Chile"25, para sólo señalar un par de casos chilenos.

\footnotetext{
${ }^{22}$ Corte IDH. Caso "La Última Tentación de Cristo"(Olmedo Bustos y otros) Vs. Chile. Fondo, Reparaciones y Costas. Sentencia de 5 de febrero de 2001. Serie C No 73, párrafo 87.

${ }^{23}$ Responsabilidad Internacional por Expedición y Aplicación de Leyes Violatorias de la Convención (Arts. 1 y 2 Convención Americana Sobre Derechos Humanos), Opinión Consultiva OC-14/94 del 9 de diciembre de 1994, Serie A No 14.

${ }^{24}$ Corte IDH. Caso Palamara Iribarne Vs. Chile. Fondo, Reparaciones y Costas. Sentencia de 22 de noviembre de 2005. Serie C No 135

${ }^{25}$ Corte IDH. Caso Almonacid Arellano y otros Vs. Chile. Excepciones Preliminares, Fondo, Reparaciones y Costas. Sentencia de 26 de septiembre de 2006. Serie C No 154.
} 
La expresión "medidas (...) de otro carácter" que utiliza la Convención en su artículo $2^{\circ}$, implica que los órganos jurisdiccionales ordinarios o especiales que contempla el ordenamiento estatal, en cuanto órganos del Estado, se encuentran vinculados directa e inmediatamente por los derechos asegurados convencionalmente, mas aún cuando el ordenamiento jurídico estatal al ratificar la Convención, la convierte en derecho interno sin que deje de ser simultáneamente derecho internacional. Así, la norma convencional en esta doble dimensión, de norma interna e internacional, vincula a los jueces ordinarios, constitucionales y otros especiales, a respetar y a garantizar los atributos y garantías de los derechos asegurados por dicha normativa en el estándar mínimo asegurado convencionalmente y conforme a las normas de interpretación contenidas en el artículo 29 de la CADH, donde están expresamente contenidos los principios "favor persona" o "pro homine" y de progresividad ${ }^{26}$, los cuales se encuentran positivados en el artículo 29 literal b) de la $\mathrm{CADH}^{27}$, como asimismo, en el artículo $5^{\circ}$ del PIDCP ${ }^{28}$, entre otros tratados de derechos humanos.

El control de convencionalidad debe concretarlo cada uno y todos los jueces cuando lo soliciten las partes, pero si ellas no lo demandan constituye un deber del juez aplicar el control de convencionalidad "ex officio", como se explicita en el caso Trabajadores Cesados del Congreso (Aguado Alfaro y otros) Vs. Perú, manteniéndose uniformemente dicha línea jurisprudencial hasta la actualidad. La CIDH entiende que los jueces nacionales conocen y deben aplicar el derecho convencional, iura novit curia $^{29}$, por ser no sólo derecho

\footnotetext{
${ }^{26}$ Ver entre otros, Pinto, Mónica. (1997). Bidart Campos, G., (2001). Amaya Villareal, Álvaro Francisco. (2005).

27 Art. 29 Literal b) CADH, prescribe que ninguna disposición del mismo puede ser interpretada en el sentido de "limitar el goce y ejercicio de cualquier derecho o libertad que pueda estar reconocido de acuerdo con las leyes de cualquiera de los estados partes o de acuerdo con otra convención en que sea parte uno de dichos estados".

${ }^{28}$ Art. 50 PIDCP: "1. Ninguna disposición del presente Pacto podrá ser interpretada en el sentido de conceder derecho alguno a un Estado, grupo o individuo para emprender actividades o realizar actos encaminados a la destrucción de cualquiera de los derechos y libertades reconocidos en el Pacto o a su limitación en mayor medida que la prevista en él. 2. No podrá admitirse restricción o menoscabo de ninguno de los derechos humanos fundamentales reconocidos o vigentes en un Estado Parte en virtud de leyes, convenciones, reglamentos o costumbres, so pretexto de que el presente Pacto no los reconoce o los reconoce en menor grado".

${ }^{29}$ El juez dispone de la facultad y el deber de aplicar las disposiciones convencionales en el litigio, aun cuando las partes no las invoquen.
} 
internacional ratificado y vigente, de aplicación preferente, sino también derecho interno. Por tanto, cada vez que un juez dentro de sus competencias y de acuerdo a los procedimientos establecidos deja de aplicar el derecho convencional que asegura los derechos fundamentales está generando un acto írrito que carece de valor jurídico, siendo un acto contrario a derecho, un acto que vulnera derechos humanos y genera responsabilidad internacional del Estado, en cuanto el juez es un agente del mismo Estado, es el Estado Juez, si ello no se corrige en el derecho interno, antes de llegar al sistema interamericano.

En esta tarea de control de convencionalidad, los jueces no sólo deben tener en consideración la norma jurídica positiva que se encuentra en el tratado, sino también la interpretación auténtica que ha establecido la $\mathrm{CIDH}$, en el ámbito de su competencia de interpretación y aplicación de la convención, en cuanto interprete último de los derechos asegurados y garantizados en la Convención, según lo dispuesto en ella misma, como lo determina la $\mathrm{CIDH}$ desde el caso Almonacid Arellano vs. Chile. La CIDH entiende que su jurisprudencia debe servir de base para la aplicación de la CADH, así lo establece claramente en diversas otras sentencias, entre ellas, "Boyce y otros vs. Barbados", cuando determina que los jueces deben "(...) tener en cuenta no solamente el tratado, sino también la interpretación que del mismo ha hecho la Corte Interamericana, intérprete última de la Convención" ${ }^{30}$. Así, la interpretación formulada por la CIDH debe entenderse incorporada a la norma interpretada mientras ella no cambie de posición, de la misma manera como se entiende operativa la interpretación de la Corte Suprema o del Tribunal Constitucional respecto de la norma constitucional interpretada, en aquellos casos en que dicha interpretación es vinculante.

No podemos sino concordar con Ferrer Mac-Gregor en su voto razonado en la sentencia de la CIDH en el Caso Cabrera García y Montiel Flores Vs. México cuando afirma que "la jurisprudencia de la Corte IDH adquiere 'eficacia directa' en todos los Estados nacionales que han reconocido expresamente su jurisdicción, con independencia de que derive de un asunto donde no han participado formalmente como 'parte material'. Lo anterior, debido a los efectos de la norma convencional interpretada, que produce 'efectos expansivos' de la jurisprudencia convencional y

\footnotetext{
${ }^{30}$ Corte IDH: Caso "Boyce y otros vs. Barbados", párrafo 78; "Caso Almonacid Arellano y otros Vs. Chile”, párrafo 124.
} 
no sólo eficacia subjetiva para la tutela del derecho y libertad en un caso particular sometido a su competencia" ${ }^{1}$.

El control de convencionalidad implica que todos los jueces de los estados partes de la Convención en cuanto expresión del Estado juez se encuentran vinculados por ésta, como asimismo por la interpretación que ha hecho la Corte Interamericana de Derechos Humanos del mencionado instrumento.

Ello implica que los estados partes del sistema deben asumir, más allá del Estado específico directamente obligado por la respectiva sentencia de acuerdo al artículo 68 numeral 1 de la $\mathrm{CADH}$, la "ratio decidendi" o "holding" de la sentencia, en cuanto interpretación fidedigna y auténtica de la Convención emanada de su intérprete final.

$\mathrm{Al}$ ratificar la $\mathrm{CADH}$ como también otros tratados sobre derechos humanos, el Estado, en el ejercicio de su potestad pública (soberanía) ha consentido en limitar su propio poder en beneficio de un bien superior al mismo, que es el respeto de la dignidad inherente a toda persona humana que se expresa en el reconocimiento de derechos humanos o fundamentales, los cuales se constituyen como un límite al ejercicio del poder estatal. En tal sentido, ello implica reconocer que el poder del Estado, la soberanía estatal, se encuentra limitada en su ejercicio por el respeto y garantía efectiva de tales derechos, lo que reconoce explícitamente el texto constitucional chileno, en su artículo $5^{\circ}$ inciso $2^{\circ}$.

Concordando con el profesor De Vergottini ${ }^{32}$, puede sostenerse que el derecho convencional, la jurisprudencia y la praxis ponen en relieve el instrumento a través del cual la interacción se manifiesta con el fin de asegurar un nivel satisfactorio de compatibilidad entre los dos órdenes, el convencional y el estatal. Es necesario tener presente como norma general que el Estado Parte y sus órganos jurisdiccionales deben respetar el derecho del tratado y la jurisprudencia de la Corte Internacional. Ello lleva a un vínculo de adecuación sucesiva a la jurisprudencia de los tribunales internacionales que debe ser garantizada por el Estado Parte, lo que frecuentemente obliga a concretar modificaciones normativas estatales de todo orden, para cumplir el objeto y fin del tratado que es el respeto y garantía efectiva de los derechos humanos, en el estándar mínimo

${ }^{31}$ Ferrer Mac-Gregor, Eduardo, en voto razonado en Caso Cabrera García y Montiel Flores Vs. México. Excepción Preliminar, Fondo, Reparaciones y Costas. Sentencia de 26 de noviembre de 2010. Serie C No 220, párrafo 79.

32 De Vergottini, Giuseppe. (2011), p. 73. 
fijado convencionalmente los cambios legislativos necesarios y a veces ajustes para garantizar los derechos humanos.

La CADH y el corpus iuris interamericano vive en la interpretación formulada por la Corte de San José que es el interprete auténtico y final de dicha Convención y cuyas sentencias son incondicionalmente vinculantes para el Estado parte como obligaciones de resultado, cuando garantizan una protección de los derechos fundamentales como estándar mínimo superior al asegurado constitucionalmente

A través de la cosa interpretada de la Corte Interamericana, la ratio decidendi de sus sentencias, debe entenderse incorporadas a las disposiciones convencionales, las que los jueces internos deben respetar. Así, la autoridad de las sentencias de la CIDH desborda ampliamente su estricto alcance jurídico para el caso concreto, lo que es común también al fallo del TEDH, en ambos casos se aplica el principio de economía procesal.

Las autoridades del Estado, nivel en el cual se encuentran también las jurisdicciones nacionales, deben conformarse a la jurisprudencia de la CIDH y del TEDH, en su caso. Ello lleva a sostener la doctrina de que las sentencias de la $\mathrm{CIDH}$ como las del TEDH se encuentran revestidas de la autoridad de "cosa interpretada" 33 , que supera la de "cosa juzgada".

La CIDH utiliza sus sentencias con autoridad de cosa interpretada, reforzando el efecto directo de sus resoluciones bajo reserva que ellos aportan una solución en términos precisos y completos a casos similares, extendiendo este efecto de la sentencia dictada contra un Estado Parte a todos los estados partes cuyo orden jurídico o práctica son igualmente concernidos por la resolución de la CIDH, pudiendo apoyarse en los artículos 1 y 2 de la CADH.

La frecuencia de casos repetitivos ante la Corte Interamericana de Derechos humanos es la prueba objetiva de que ciertas jurisdicciones de algunos estados miembros del sistema no respetan la obligación de cumplir seriamente y de buena fe sus obligaciones jurídicas vinculantes de aplicar el corpus iuris interamericano y la interpretación auténtica del mismo hecha por la Corte Interamericana de Derechos Humanos. Ello requiere un análisis y reflexión serena y seria de tales jurisdicciones, especialmente si ellas son cortes supremas o tribunales constitucionales, ya que a ellas les corresponde como órganos de cierre del sistema jurisdiccional interno la máxima responsabilidad, en términos de lo señalado por Branco Hrvatin, Presidente de la Corte Suprema de Croacia, "a ellos les

${ }^{33}$ Ver SUdRE, Frederic. (2003), p. 577. 
incumbe aplicar la Convención, tal como ella es interpretada por la Corte (...) en el seno del orden jurídico interno, y de incitar a las jurisdicciones internas de aplicarla directamente cuando ellas resuelven litigios que son parte de su competencia" 34 . No es una buena señal de las jurisdicciones de un Estado Parte que el impulso de la aplicación del corpus iuris interamericano vengan de los tribunales de primera y segunda instancia y no de las jurisdicciones superiores, ya que ello priva a las primeras de apoyarse en estándares más consensuados.

Debe tenerse presente que la Corte Interamericana es una sola para todos los casos que deben ser resueltos de todos los estados partes del sistema interamericano, por ello la lógica del control de convencionalidad desarrollada por los jueces internos va en la línea de que los tribunales nacionales siguiendo la jurisprudencia de la CIDH puedan resolver los casos nacionales, sin hacer incurrir por sus resoluciones judiciales de Estado Juez al Estado Parte en responsabilidad internacional por violación de derechos humanos, además de atochar a la $\mathrm{CIDH}$ con casos similares ya resueltos de acuerdo al principio de economía procesal, donde existe una clara línea jurisprudencial. En efecto, la garantía de un sistema convencional de derechos exigible a los estados partes como estándar mínimo viene dado por el seguimiento de buena fe de dichos estándares interpretativos y del desarrollo de una doctrina común en los estados vinculados por el tratado, generando un espacio convencional sobre derechos cubierto por el corpus iuris interamericano, base de un derecho público común mínimo interamericano que asegure y garantice derechos reales y efectivos para las personas que habitan dicho espacio.

Tal perspectiva, no es diferente de la existente en Europa, donde el TEDH ha desarrollado métodos coercitivos de cierre del diálogo de jueces a favor del respeto de la autoridad de interpretación que ella determina en sus sentencias. En tal perspectiva ella produce los denominados "arrêts pilotes" o las sentencias de orientación ${ }^{35}$, solicitando al órgano normativo nacional la modificación de normas jurídicas internas que contravienen los estándares convencionales y que generan violación de derechos humanos.

Las sentencias de orientación constituyen una técnica que consiste en dar a una sentencia de principio un efecto cuasi "erga omnes" a cuyo título los Es-

\footnotetext{
${ }^{34}$ Hrvatin, Branco. (2010). "Dialogue entre juges" (2010). Cour Européenne des Droits de l'Homme. Conseil de L'Europe. Strasbourg, 2010. http://www.echr.coe.int/NR/rdonlyres/3F410EB0-4980-456298F1 B30641C337A5/0/DIALOGUE_2010_EN.pdf

35 De Vergottini, Giuseppe, (2011) p. 73. Lambert-Abdelgawad, E. (2004), pp. 203-224.
} 
tados que no son partes en el litigio son invitados a asumir la ratio decidendi de la resolución en su derecho interno, de lo cual es un ejemplo entre otros, la sentencia de la Grande Chambre Apicella ${ }^{36}$,Broniowski ${ }^{37}$, Hutten-Czapska ${ }^{38}$, Messina ${ }^{39}$.

El TEDH en el caso Hutten-Czapska ${ }^{40}$, la Gran Sala (Grande Chambre) ha estimado en su resolución que no es necesario que un número dado de requerimientos similares se encuentre pendiente para que una situación sea calificada de sistemática y justifique la aplicación de las sentencias "pilote" ${ }^{\text {, }}$ sino que debe tenerse presente el flujo de asuntos susceptibles de ser llevados ante la TEDH en el futuro próximo, con el fin de prevenir la congestión de su función por asuntos repetitivos.

La Comisión de Venecia ${ }^{42}$ ha solicitado al juez europeo de Estrasburgo establecer en el texto de sus sentencias, una indicación tan precisa como sea posible, de la naturaleza y de la dimensión de la violación constatada como del tipo de medidas adecuadas que debe adoptar el Estado Parte infractor para remediar tal ausencia normativa o de conductas en el caso respectivo.

Por otra parte, la Resolución (2004) 3 del Comité de Ministros de la Unión Europea invita al TEDH, en la medida de lo posible, a identificar en las resoluciones o sentencias en que ella constata una violación de la Convención aquello que, según ella, constituye un problema estructural subyacente y la fuente de este problema, de manera de ayudar a los estados partes a encontrar la solución apropiada y al Comité de Ministros criterios claros para supervigilar el cumplimiento de las sentencias. Esta técnica fue inaugurada en el asunto Broniowski ${ }^{43}$.

\footnotetext{
${ }^{36}$ TEDH, Gr. Ch., 29 marzo 2006, Apicella c/ Italia, req. No 64890/01.

${ }^{37}$ TEDH, Gr. Ch., Broniowski cl Pologne. No 31443/96.

${ }^{38}$ TEDH. Gr. Ch., 19 junio 2006, Hutten-Czapska cl Pologne, req. No 35014/97.

39 TEDH. Messina cl. Itália, de 10 de noviembre de 2004, No 25498/94.

${ }^{40}$ TEDH. Gr. Ch., 19 junio 2006, Hutten-Czapska c/ Pologne, req. No 35014/97.

${ }^{41}$ Ver SuDRE, Fréderic (2011). Droit Européen et Internacional des Droits de l'Homme. Décima edición, revisada y aumentada. Ed. PUF, 2011, p. 810.

${ }^{42}$ Avis No 209/2002, CDL-AD (2002) 34 de la comisión de Venecia sobre las sentencias del Tribunal Europeo de Derechos Humanos adoptada en la 53 sesión plenaria (13-14 de diciembre de 2002).

43 TEDH, Gr. Ch., 22 de junio de 2004, Broniowski c/ Pologne, req. No 31443/96. Ver sobre la materia el artículo de Lambert-Abdelgawad, E. (2004). Asimismo ver, Pradel, Jean; Corstens Geert y VermeuLEN, Gert (2009).
} 


\subsection{El Estado Parte en la CADH tiene la obligación juridica de cumplir las sentencias de la Corte Interamericana de Derechos Humanos} (artículos 67 a 69 de la CADH)

Los Estados Partes de la CADH, al reconocer la jurisdicción obligatoria y vinculante de la Corte Interamericana de Derechos Humanos (CIDH), de acuerdo con los artículos 67 a 69 de la Convención, que determina una obligación de resultado respecto de lo ordenado por la sentencia de la $\mathrm{CIDH}$ cuyo contenido puede ordenar como medida de reparación incluso la reforma misma de la Constitución, como ocurrió en el caso "La última tentación de Cristo", donde la sentencia de la CIDH ordenó que el Estado de Chile debía modificar el artículo 19 No 12, inciso final de la Constitución, por ser contrario al artículo 13 de la Convención que asegura el derecho a la libertad de expresión e información sin censura previa, lo que el Estado chileno cumplió.

La lógica de la garantía colectiva instituida por el mecanismo convencional que los estados partes han libre, voluntaria y soberanamente aceptado, tiene por objeto establecer una protección mínima común de los derechos asegurados y garantizados por el corpus iuris interamericano que todos deben esforzarse en cumplir de buena fe. El sistema determina que la sentencia de la $\mathrm{CIDH}$ tiene un carácter definitivo y final, goza de cosa juzgada formal y material. La sentencia de la CIDH es la última palabra como lo es el TEDH en el sistema europeo, porque son la palabra final, la que se pronuncia después que se han pronunciado los tribunales domésticos de los estados partes, ordinarios, especiales y, eventualmente, las jurisdicciones constitucionales competentes, pudiendo ordenar la sustitución de normas jurídicas, determinar la carencia de valor de resoluciones judiciales contrarias a los estándares de derechos humanos, la realización de nuevos juicios

Rechazar por los órganos del Estado Parte la protección convencional, en nombre de una premisa metodológica, la que no es en realidad más que un a priori ideológico, no tiene validez en la perspectiva de la aplicación de buena fe y de no imponer obstáculos de derecho interno al respeto y garantía de los derechos convencionales (arts. 26 y 27 Convención de Viena sobre Derecho de los Tratados) como estándares mínimos regionales.

Como ha precisado la CIDH, en el caso "Almonacid Arellano vs. Chile":

"123. La descrita obligación legislativa del artículo 2 de la Convención tiene también la finalidad de facilitar la función del Poder Judicial de tal forma que 
el aplicador de la ley tenga una opción clara de cómo resolver un caso particular. Sin embargo, cuando el Legislativo falla en su tarea de suprimir y/o no adoptar leyes contrarias a la Convención Americana, el Judicial permanece vinculado al deber de garantía establecido en el artículo 1.1 de la misma y, consecuentemente, debe abstenerse de aplicar cualquier normativa contraria a ella. El cumplimiento por parte de agentes o funcionarios del Estado de una ley violatoria de la Convención produce responsabilidad internacional del Estado, y es un principio básico del derecho de la responsabilidad internacional del Estado, recogido en el Derecho Internacional de los Derechos Humanos, en el sentido de que todo Estado es internacionalmente responsable por actos $\mathrm{u}$ omisiones de cualesquiera de sus poderes u órganos en violación de los derechos internacionalmente consagrados, según el artículo 1.1 de la Convención Americana" ${ }^{44}$.

Esta realidad jurídica que implica que los estados partes se encuentran en la obligación de respetar y garantizar los derechos asegurados convencionalmente, a través de sus diversos órganos y agentes del Estado, lleva a determinar también las obligaciones que corresponden a los jueces nacionales, para que a través de sus actos jurisdiccionales no vulneren los derechos, sino que como corresponde a sus obligaciones jurídicas contribuyan a respetarlos, asegurarlos y garantizarlos, impidiendo así hacer incurrir al Estado en responsabilidad internacional por violación de derechos humanos en su calidad de Estado juez.

En tal perspectiva, no debe olvidarse que cuando llega un caso al sistema interamericano de protección de derechos fundamentales y el Estado es condenado, es porque ha fallado una instancia jurisdiccional del sistema nacional, ya que para acceder al sistema interamericano deben haberse agotado previamente las instancias jurisdiccionales internas, así ocurrió con los casos chilenos "La última tentación de Cristo" ${ }^{45}$, "caso Palamara"46, caso "Claude

\footnotetext{
${ }^{44}$ Corte IDH. Caso Almonacid Arellano y otros Vs. Chile. Excepciones Preliminares, Fondo, Reparaciones y Costas. Sentencia de 26 de septiembre de 2006. Serie C No 154, párrafo 123.

${ }^{45}$ Corte IDH. Caso "La Última Tentación de Cristo"(Olmedo Bustos y otros) Vs. Chile. Fondo, Reparaciones y Costas. Sentencia de 5 de febrero de 2001. Serie C No 73. El caso llega a la CIDH después de una sentencia de la Corte Suprema de Justicia.

${ }^{46}$ Corte IDH. Caso Palamara Iribarne Vs. Chile. Fondo, Reparaciones y Costas. Sentencia de 22 de noviembre de 2005. Serie C No 135. El caso llega a la CIDH después de una sentencia de la Corte de Apelaciones de Punta Arenas y Juzgado Naval de Magallanes.
} 
Reyes vs. Chile" ${ }^{77}$ y caso "Almonacid y otros vs. Chile" 48 y "Atala y niñas vs. Chile" 49 .

Como bien señala Sagüés, el "Estado que no esté dispuesto a pagar ese precio para sumarse al proceso integrativo en el ámbito de los derechos humanos, le quedará la salida honrosa (si decide afrontar el costo jurídico y político que ella también tiene) de denunciar al Pacto de San José de Costa Rica, e irse de él según el trámite de retiro. Lo que no parece honroso es ratificar el Pacto y después argumentar que no cumple alguna de sus cláusulas porque ella no coincide con su Constitución"so.

Cabe señalar que el control de convencionalidad per se no es exclusivo del sistema interamericano, este es un control jurídico y jurisdiccional que se concreta en el plano internacional o supranacional en diversos sistemas jurídicos, el que posibilita determinar el grado de cumplimiento de las obligaciones convencionales de un Estado Parte a partir de la coherencia entre la conducta del Estado y las obligaciones determinadas por la norma jurídica convencional. Este control de convencionalidad lo ejerce la Corte Europea de Derechos Humanos respecto de los estados partes de Convención Europea de Derechos Humanos, desde hace décadas. El examen de convencionalidad verifica la adecuación de la conducta de un Estado Parte a la norma convención respectiva.

Dicho control de convencionalidad en sede de jueces nacionales implica asumir por parte de éstos, que el derecho vigente y vinculante, no es sólo el de fuente interna, sino también aquel emanado de fuente internacional el que debe ser asegurado y garantizado en la concreción de sus actos jurisdiccionales, de manera que la inobservancia de un juez de las normas convencionales o de la interpretación de las mismas hecha por el órgano encargado de su inter-

\footnotetext{
47 Corte IDH. Caso Claude Reyes y otros Vs. Chile. Fondo, Reparaciones y Costas. Sentencia de 19 de septiembre de 2006. Serie C No 151. La CIDH conoce de la materia después de pronunciamientos de sentencias en Recurso de Protección de la Corte de Apelaciones de Santiago y de sentencia en recurso de Queja de la Corte Suprema de Justicia.

${ }^{48}$ Corte IDH. Caso Almonacid Arellano y otros Vs. Chile. Excepciones Preliminares, Fondo, Reparaciones y Costas. Sentencia de 26 de septiembre de 2006. Serie C No 154. La CIDH se pronuncia después de sentencias de la Corte Marcial y de la Corte Suprema de Justicia.

${ }^{49}$ Corte IDH. Caso Atala Riffo y Niñas Vs. Chile. Fondo, Reparaciones y Costas. Sentencia del 24 de febrero de 2012. Serie C No 239. La sentencia determina responsabilidad por acto jurisdiccional que incurre en discriminación por conducta lésbica.

50 Sagüés, Néstor Pedro. (2010), p. 125.
} 
pretación y aplicación, implica responsabilizar al Estado por dicho incumplimiento, al concretar un ilícito internacional. El control de convencionalidad constituye como señala Albanese una "garantía destinada a obtener la aplicación armónica del derecho vigente" ${ }^{\text {, }}$, con sus fuentes internas, internacionales o supranacionales.

Las jurisdicciones internacionales que controlan la interpretación de un tratado de aplicación directa, se ubican al primer nivel y sitúan bajo su supervigilancia y control la actuación de las jurisdicciones de los estados firmantes. Las decisiones jurisdiccionales de las primeras son vinculantes para las segundas en su calidad de Estado juez parte de la Convención. La sentencia de la CIDH y la interpretación que ella realiza de la $\mathrm{CADH}$ en su interpretación tiene el mismo efecto directo y la misma primacía que el tratado mismo. En esta perspectiva no debe olvidarse el artículo 62.3 de la $\mathrm{CADH}$ que es equivalente al artículo 32 de la $\mathrm{CEDH}$, que otorgan a las dos cortes señaladas el carácter de interprete auténtico y final de las respectivas convenciones, lo que va acompañado del carácter irrevocable de sus fallos, de la preclusión de un juicio posterior mediante la aplicación del principio Non bis in idem, y del precedente que se crea para los casos futuros, estableciéndose una especie de prejudiciabilidad en la materia específica ${ }^{52}$.

Este mecanismo se ha reforzado en la realidad interamericana por la puesta en cuestión de la autoridad de cosa juzgada de los tribunales nacionales, especialmente en materia penal, debiendo reexaminarse las decisiones jurisdiccionales internas consideradas contrarias a la Convención Americana sobre Derechos Humanos y violadoras de derechos humanos, al ser estimadas dichas sentencias irritas y nulas desde su inicio, como ocurrió en el caso chileno con la sentencia de la CIDH Almonacid Arellano y otros vs. Chile, que consideró que carecían desde un inicio de efectos las sentencias de la Corte Suprema de Justicia y de la judicatura militar, en el primer caso, por resolver la contienda de competencia a favor de un tribunal militar que, a la época, no respondía a los estándares mínimos de juez natural y de tribunal independiente e imparcial, como asimismo por vulnerar el derecho a la jurisdicción y debido proceso, desconociendo el carácter de delitos imprescriptibles e inamnistiables aquéllos de aquellos de lesa humanidad y contrarios a los derechos humanos.

${ }^{51}$ Albanese, Susana. (Coord.) (2008), p. 15.

52 Sobre la materia ver Queralt, Argelia. (2003), pp. 218 y ss. 
La permeabilidad del orden jurídico nacional a las decisiones internacionales se ha acrecentado en el sistema interamericano como también en el sistema europeo de derechos humanos ${ }^{53}$.

En el control de convencionalidad que ejerce la CIDH se concreta una especie de comunicación ínter jurisdiccional entre ella y los tribunales nacionales de todo orden ${ }^{54}$, una interacción que tiene un carácter más bien vertical por la posición de control final que desarrolla la CIDH respecto de la aplicación de los derechos efectuada por las jurisdicciones domésticas. En efecto, los tribunales domésticos o nacionales deben asegurar una interpretación del derecho interno conforme a la convención, efectuando un control de convencionalidad de manera de garantizar la respuesta de la normativa interna del Estado Parte a la obligación contraída a través de la Convención de asegurar y garantizar los derechos en el estándar mínimo asegurado en el vínculo jurídico obligatorio que establece la CADH. En tal sentido, los tribunales domésticos deben implementar la doctrina del seguimiento de la jurisprudencia de la CIDH, con el margen de apreciación que la $\mathrm{CIDH}$ pueda dejar a los tribunales nacionales, el cual en el sistema interamericano es escaso.

\section{EL JUEZ NACIONAL COMO JUEZ NATURAL DEL CORPUS IURIS INTERAMERICANO}

El juez nacional es el juez natural de la CADH y del corpus iuris interamericano. Es él quien, en primer lugar, hace la aplicación y arriesga la interpretación del control de convencionalidad. Es en reacción, positiva o negativa, a sus tomas de posición preliminares que la CIDH construye el derecho interamericano. Se concreta así entre las jurisdicciones de los estados partes y la CIDH un diálogo y cooperación leal, donde la base de las discusiones ulteriores de la Corte Interamericana está constituida por las decisiones de los jueces nacionales.

El juez interno como juez de convencionalidad se inserta en el principio de subsidiaridad de la jurisdicción interamericana ${ }^{55}$, ésta determina estándares

\footnotetext{
${ }^{53}$ Ver Камтто, Maurice (2003), pp. 393-460.

${ }^{54}$ Ver voto concurrente de Ferrer Mac-Gregor en la sentencia de la CIDH, Caso Cabrera García y Montiel Flores Vs. México. Excepción Preliminar, Fondo, Reparaciones y Costas. Sentencia de 26 de noviembre de 2010. Serie C No 220, párrafo 70; ver también, GARCÍA-SAYÁn, Diego. (2005).

55 Agullar Cavallo, Gonzalo (2012), pp. 477-478.
} 
mínimos que deben respetar los estados partes del sistema interamericano, teniendo los estados partes la libertad para asegurar y garantizar en su ordenamiento jurídico interno los derechos con estándares más altos que los que consigna el corpus iuris interamericano, aplicando las instancias nacionales de carácter jurisdiccional una protección de los derechos más amplia y superior al estándar mínimo conferido por la $\mathrm{CIDH}$, de acuerdo al principio pro homine o favor persona. Nada impide al Estado Parte y al juez nacional ir más allá de las soluciones de la Corte de San José, desarrollando una tarea más dinámica que la que ha desarrollado la Corte Interamericana, lo que, a su vez, alimenta el diálogo con esta última, posibilitando la actualización de la jurisprudencia interamericana. Esta perspectiva se aplica en los mismos términos en el sistema europeo de derechos humanos ${ }^{56}$.

El juez nacional es el juez de derecho común de la Convención; en tanto que tal, conoce y resuelve un contencioso antes que éste llegue a manos de la Corte Interamericana, por tanto, respondiendo a los medios invocados por las partes deberá considerar en lo pertinente la CADH y el corpus iuris interamericano, pronunciándose sobre la aplicabilidad de los derechos garantizados por ella para verificar luego las condiciones de su ejercicio, debiendo realizar una adecuada interpretación, la que debe considerar la jurisprudencia de la $\mathrm{CIDH}$ si existe sobre la materia. El no hacerlo genera el riesgo de la condenación del Estado parte por violación de derechos humanos, siendo el acto responsable de tal vulneración el de un tribunal nacional (Estado juez).

Como ha señalado Jean-Paul Costa, respecto de la Convención Europea de Salvaguarda de los Derechos Humanos, "los jueces nacionales deben interpretarla, aplicarla, hacerla prevalecer sobre reglas y prácticas incompatibles. Entre más lo hagan menos nuestra Corte deberá intervenir, salvo para ser este último baluarte que concibieron los padres fundadores" 57 .

Asimismo, como sostiene Geert Corstens, Presidente de la Corte Suprema de los Países Bajos (Holanda), en su intervención en "Diálogo de Jueces 2010", La protección de los derechos del hombre consignados en la Convención incumbe en primer lugar a los estados mismos. Ellos deben velar a su efica-

${ }^{56}$ Morrone, Andrea (2011), p. 195.

57 Costa Jean-Paul (2010). En alocución de inauguración del "Dialogue entre juges. 2010". Cour Européenne des droits de l'homme. Conseil de L'Europe. Strasbourg, 2010.http://www.echr.coe.int/ NR/rdonlyres/3F410EB0-4980-4562-98F1 B30641C337A5/0/DIALOGUE_2010_EN.pdf 
cia y tomar las medidas correctivas en caso de falla" ${ }^{8}$. En efecto, el sistema interamericano sólo juega un rol complementario y únicamente interviene cuando las autoridades nacionales no han cumplido o han cumplido mal su tarea, lo que exige que los tribunales nacionales tomen en serio su tarea de juez del corpus iuris interamericano, haciendo efectivo el beneficio concreto de la protección de los derechos de las personas, beneficiadas con los estándares mínimos de protección convencional, haciendo efectivo el principio de subsidiaridad. Le ayudará al juez nacional en esta tarea, que constituye una dimensión específica de su obligación constitucional contenida en el artículo $5^{\circ}$ inciso $2^{\circ}$ de la Constitución de asegurar y promover los derechos esenciales de la persona garantizados por la Constitución y por los tratados ratificados y vigentes, el seguir de cerca la jurisprudencia de la Corte Interamericana de Derechos Humanos y aplicarla con diligencia y de buena fe.

El sentido del sistema interamericano de Derechos Humanos, desde su fundación, es el de establecer un instrumento jurídico positivo que asegura y garantiza derechos humanos que los Estados partes se han comprometido a respetar como estándar mínimo en su ordenamiento jurídicos y en las actuaciones de todos sus órganos y autoridades, sean estas gubernamentales, legislativas, administrativas o jurisdiccionales; además de establecer una jurisdicción de control de la actuación de los Estados partes con facultades jurisdiccionales vinculantes para ellos que determina su cumplimiento como obligaciones de resultado. El sistema interamericano refuerza así la función de los órganos jurisdiccionales internos, a todos los jueces del Estado Parte, en la medida que fortalece sus competencias y su independencia, como asimismo les permite aplicar los estándares de aseguramiento y garantías de los derechos en sus atributos en el estándar mínimo exigido convencionalmente, descartando las normas jurídicas internas que se encuentran por debajo del mismo, aplicando el principio "pro homine" o "favor persona".

El juez interno ejerce así el control de convencionalidad liberándose de su remisión a la ley interna cuando esta vulnera un derecho convencional, pudiendo así aniquilar los efectos negativos de un precepto legal o administrativo contrario a los derechos fundamentales garantizados convencionales.

\footnotetext{
${ }^{58}$ Corstein, Geert (2010). "Dialogue entre juges.2010". Cour Européenne des Droits de l'Homme. Conseil de L'Europe. Strasbourg, 2010. http://www.echr.coe.int/NR/rdonlyres/3F410EB0-4980-456298F1 B30641C337A5/0/DIALOGUE_2010_EN.pdf
} 
Esta perspectiva del juez nacional se concreta mediante la modalidad de la lectura e interpretación del derecho interno conforme al derecho convencional cuando éste protege mejor el derecho considerado que lo que realiza el derecho interno o realiza una interpretación más restrictiva de las limitaciones de los derechos. Así puede señalarse que la Convención Americana sobre Derechos Humanos y el Convenio Europeo de Derechos Humanos comparten la determinación que las jurisdicciones internas de los Estados partes sean jueces convencionales, sin perjuicio de otorgar una autoridad unificadora a la jurisdicción internacional creada por el respectivo sistema internacional de protección de derechos humanos, quien ejerce jurisdicción vinculante y obligatoria para los estados partes, además de desarrollar la interpretación auténtica y final del respectivo corpus iuris.

La interpretación conforme al corpus iuris interamericano la concreta el juez nacional sin necesidad de esperar que el Estado Parte haya sido condenado, sino que saca de la sentencia condenatoria de otro Estado Parte, la ratio decidendi del mismo, aplicándola al caso o litigio nacional a fin de evitar una eventual condenación por parte de la CIDH, si el asunto del cual conoce es similar a otros ya previamente resueltos y donde existe una línea jurisprudencial asentada.

Las jurisdicciones nacionales pueden buscar voluntariamente y de buena fe en la ratio decidendi de la jurisprudencia de la Corte Interamericana la norma y los medios jurídicos necesarios para la construcción de sus propias soluciones.

Cuando el juez nacional procede así, el juez interno completa el derecho interno en virtud del control de convencionalidad, agregando a las reglas impuestas por el legislador nacional, las exigidas por la $\mathrm{CADH}$ según la interpretación hecha por la Corte Interamericana como intérprete final de la misma. El juez interno no puede sino aceptar cuenta tenida de la autoridad de la sentencia emanada de la Corte de San José, de su contenido como cosa interpretada en cuanto intérprete auténtico y final de la misma, como asimismo, de la obligación de resultado que ella implica para todos los órganos del Estado Parte.

El juez nacional debe aplicar no sólo el corpus iuris interamericano y la jurisprudencia de la CIDH, sino también los métodos de interpretación desarrollados por la CIDH: la interpretación evolutiva, dinámica y finalista; el uso de principios básicos de interpretación de derechos: "pro homine" o "favor persona”, progresividad, proporcionalidad, para sólo señalar algunos de ellos, los que constituyen una fuente de ampliación de su potestad jurisdiccional. 
Esta tarea del juez nacional de anticipación utilizando el corpus iuris interamericano, sirve doblemente al justiciable. Por una parte le evita un recurso largo y fastidioso ante la jurisdicción interamericana, iniciándolo ante la Comisión Interamericana de Derechos Humanos para luego llegar a la Corte Interamericana. Por otra parte, permite el enriquecimiento mutuo de la jurisprudencia interamericana y nacional por una mayor efectividad de los derechos convencionales.

El desarrollo de este control de convencionalidad interno exige un esfuerzo de capacitación en el corpus iuris interamericano y un adecuado conocimiento de la jurisprudencia de la Corte Interamericana en materia de los respectivos derechos y principios de interpretación de ellos, lo que debe ser conocido por los jueces nacionales de todos los niveles, jerarquía y materia, lo que requiere su incorporación en los planes de Estudios de las Facultades de Derechos y las escuelas judiciales.

Lejos de restringir el poder del juez nacional, el sistema de la Convención Americana sobre Derechos Humanos permite al juez nacional o doméstico ampliar el ámbito de su función jurisdiccional, reforzando su misión constitucional de guardián de los derechos humanos.

Asegurar y garantizar los atributos y garantías de los derechos en el respeto de los estándares mínimos fijados por el corpus iuris interamericano y dentro del marco de la "cosa interpretada" por la Corte Interamericana de Derechos Humanos en el orden interno, en tanto que juez de derecho común del sistema de la $\mathrm{CADH}$, provee al juez chileno de nuevos elementos para ejercer su función jurisdiccional, que hasta el momento ha utilizado muy marginalmente y que es hora de utilizarlos con mayor vigor, empoderándose de esta tarea mediante el desarrollo del control de convencionalidad.

El control de convencionalidad es así una nueva arma en manos de todo juez nacional, de toda instancia, de toda jurisdicción, que valoriza su posición institucional dentro del Estado Constitucional Democrático, cuyo componente más significativo desde el punto de vista sustantivo es la defensa y garantía de la dignidad humana y de los derechos esenciales que derivan de la misma, en su concreción de la tarea de administrar justicia.

El control de convencionalidad fortalece el diálogo del juez nacional con la Corte Interamericana de Derechos Humanos, reforzando la posición del juez nacional en relación a los demás órganos estatales, posibilitando el control de convencionalidad de las normas jurídicas internas, pudiendo aplicar preferentemente los derechos contenidos en el derecho convencional como pará- 
metro mínimo para determinar la conformidad de la legislación y las normas administrativas con las exigencias que derivan de la obligación erga omnes de respetar y garantizar los derechos asegurados por el corpus iuris interamericano de acuerdo al artículo 1 de la CADH y de adecuar a través de los medios jurisdiccionales la aplicación e interpretación del derecho interno a una interpretación conforme al corpus iuris interamericano, conforme al mandato del artículo $2^{\circ}$ de la CADH. Esta no es una tarea nueva, solo una tarea inaplicada, ya que ella está prevista expresamente en la Convención Americana sobre Derechos Humanos y su aplicación es obligación jurídica concretarla desde la vigencia de dicha convención en Chile, vale decir, desde 1991, como lo hacen muchos jueces de otros países de América Latina, como asimismo, como lo realizan todos los jueces nacionales de los países europeos desde la segunda mitad del siglo pasado teniendo como parámetro de control la Convención Europea de Derechos Humanos ${ }^{59}$.

Este examen ordinario de convencionalidad de leyes y potestad reglamentaria que debe hacer todo juez chileno en relación a la CADH y los tratados y convenciones complementarios, posibilita al juez, en la práctica un control tan o más potente que el que desarrolla el Tribunal Constitucional respecto del bloque de constitucionalidad de derechos, ya que si bien el control de constitucionalidad de preceptos legales está concentrado en el Tribunal Constitucional a través de controles preventivos y reparadores, pudiendo ser los segundos abstractos o concretos como determina el art. 93 numerales 6 y 7 de la Constitución; el control de convencionalidad posibilita en base al corpus iuris interamericano aplicar un control similar, ya que posibilita contrastar la legislación interna con los atributos y garantías que integran los derechos convencionales, en cuanto estándar mínimo, deben ser garantizados por todo juez nacional, teniendo presente que estos derechos fijan contenidos que en algunos casos depasan los atributos de los derechos asegurados constitucionalmente, por lo que los jueces nacionales en la aplicación del control de convencionalidad pueden evitar que el Estado Juez sea condenado por vulnerar dichos estándares que el Estado de Chile se comprometió a respetar y garantizar al ratificar la $\mathrm{CADH}$, cumpliendo de buena fe la obligación convencional y sin oponer obstáculos de derecho interno para ello.

Así, frente a un derecho fundamental, el respeto de las obligaciones internacionales no puede constituir una disminución de la protección respecto de

59 Ver De Bechillon, D. (1998), p. 226. De Gouttes, R. (1994). 
aquella que esté dispuesta como mayor por el ordenamiento jurídico interno, pero si constituye un deber jurídico y un instrumento eficaz para ampliar la tutela del derecho fundamental cuando la obligación convencional determina una protección y garantía superior como estándar mínimo que la que establece el ordenamiento jurídico interno.

La protección de los derechos fundamentales por los ordenamientos nacionales e internacional y por los tribunales nacionales y la Corte Interamericana, potencia tales derechos en esta tutela de carácter multinivel, jurisdicción ordinaria o especial, Tribunal Constitucional y Corte Interamericana de Derechos Humanos, lo que establece una combinación de carácter virtuoso, generando la obligación del legislador nacional de adecuarse a los principios mínimos que exige el derecho convencional de derechos humanos determinados por el corpus iuris interamericano para no generar responsabilidad por violación de derechos humanos por parte del Estado legislador, dando a la normativa interna una dimensión al menos equivalente al estándar mínimo exigido por la CADH y la interpretación concretada por la CIDH, y la obligación del Tribunal Constitucional en la hipótesis de que sea imposible una interpretación adecuadora, de no consentir que pueda continuar aplicándose y teniendo eficacia en el ordenamiento jurídico chileno una norma jurídica legal o administrativa que contenga un déficit de aseguramiento y garantía de un derecho fundamental inferior a la exigida por el estándar mínimo interamericano. Ello implica que el Tribunal Constitucional debe integrar necesariamente al parámetro de control de constitucionalidad los estándares mínimos respecto de atributos y garantías de los derechos asegurados por el sistema interamericano, utilizando el principio "pro homine" o "favor persona”. Ello posibilita al Tribunal Constitucional realizar simultáneamente el control de constitucionalidad exigido constitucionalmente y el control de convencionalidad exigido por el sistema interamericano, posibilitando así los plus de protección de derechos que estén contenidos tanto en la Constitución como en el corpus iuris interamericano.

Ello a su vez, implica la inauguración de un diálogo entre los jueces ordinarios y el Tribunal Constitucional, el que se desarrolla fuera del control de constitucionalidad que determina la Constitución, donde tribunales ordinarios y Tribunal Constitucional tiene la función concurrente de aplicar el control de convencionalidad, cada uno dentro de sus competencias y procedimientos determinados por el ordenamiento jurídico interno, debiendo armonizar y coordinar su jurisprudencia en materia de estándares mínimos. 
El juez nacional es quien debe aplicar el control de convencionalidad por regla general en primer lugar al conocer de un caso contencioso o de jurisdicción voluntaria, como tarea ordinaria en su función jurisdiccional, debiendo en dicho conocimiento y resolución integrar y aplicar el corpus iuris interamericano y los estándares mínimos de derechos con preferencia respecto de disposiciones de derecho interno que se encuentren por debajo del mismo, como asimismo aplicar las disposiciones de derecho interno que constituyan un estándar de protección superiores al que establece el corpus iuris interamericano, de acuerdo al principio "pro homine" o "favor persona" ${ }^{\text {", }}$ lo que implica un diálogo permanente, tanto con el Tribunal Constitucional, como con la Corte Interamericana de Derechos Humanos.

Esta perspectiva y aproximación constituye una concepción que asume la relación complementaria y armónica entre el ordenamiento jurídico interno y convencional, asumiendo la realidad de un ordenamiento jurídico más complejo que aquel tradicional al que estaban acostumbrados y que formaba parte del paradigma mental del juez nacional hasta los dos primeros tercios del siglo XX, sin que éste haya sido desplazado totalmente, el cual sigue siendo un fantasma sentado sobre su propia tumba, ya que aún existe una parte significativa de jueces nacionales que se niegan a asumir la nueva realidad del derecho de los derechos fundamentales con un parámetro integrado por las fuentes constitucionales y del derecho internacional de los derechos humanos, que debe armonizar de acuerdo al principio "pro homine" o "favor persona", en cuanto la protección de la dignidad humana y sus derechos fundamentales (ius commune público interamericano y constitucional de los Estados partes) constituye el principio y regla básica y fundamental para la interpretación y aplicación del derecho constitucional e internacional del siglo XXI.

El juez nacional debe proceder a realizar el control de convencionalidad, con un adecuado conocimiento y comprensión del corpus iuris interamericano y de la jurisprudencia de la Corte Interamericana de Derechos Humanos, ello le permitirá pronosticar prudentemente cual sería la solución de conformidad con el corpus iuris interamericano en casos contenciosos inéditos que le toque resolver, cuya diversidad puede ser infinita. Por otra parte, debe tener competencia, habilidad y destreza suficiente en el manejo de la interpretación de los derechos humanos y de las reglas de interpretación vinculantes contenidas en el artículo 29 de la $\mathrm{CADH}$, especialmente el principio de progresividad y pro

${ }^{60}$ En el mismo sentido, NASH RoJAS, Claudio. (2012), pp. 362-363. 
homine o favor persona ${ }^{61}$. Si el juez nacional ordinario o constitucional, no actúa adecuadamente y prudentemente en la materia arriesga la condenación posterior del Estado por parte del la CIDH, por violación de derechos humanos como consecuencia de la actuación violatoria de la Convención y de los derechos humanos por parte del Estado Juez.

Los jueces nacionales pueden y deben tener una actitud activa de cooperación y de coordinación voluntaria con la $\mathrm{CIDH}$, donde el juez nacional no solamente buscará comprender el espíritu de las soluciones jurisprudenciales emitidas por la $\mathrm{CIDH}$, sino que asume un rol activo de interpretación y aplicación de la Convención en derecho interno.

\section{El diálogo de las JURISDicciones NaCionales CON La CIDH y las Distintas MODALIDADES DE INTERPRETACIÓN DESARROLLADAS POR EL JUEZ NACIONAL}

En un ordenamiento internacional regional se presenta como inevitable la búsqueda de un equilibrio entre la competencia de intervención confiada al órgano de la entidad interestatal, basada en un tratado, y los órganos del estado parte, basada sobre las constituciones de los estados partes. Al adoptar su propio pronunciamiento una Corte Internacional debe tener en cuenta las atribuciones residuales de los órganos estatales y los tribunales o cortes estatales debe tener en cuenta el ámbito de potestades y competencias que el Estado ha transferido al órgano de la entidad nacional. Se establece así inevitablemente registros entre los dos órdenes de tribunales y la interacción entre los tribunales ${ }^{62}$.

El diálogo de los jueces nacionales con una Corte internacional de Derechos Humanos se transforma, como sostiene Hervé Suxe, en "un procedimiento por el cual el juez nacional discute el sentido de una disposición convencional" ${ }^{\prime 3}$. Un debate basado en un intercambio de argumentos entre el juez interno y la Corte Interamericana de Derechos Humanos en base al corpus iuris interamericano en nuestro ámbito regional, como ya se desarrolla en Europa entre el Tribunal Europeo de Derechos Humanos y las judicaturas nacionales ordinarias, administrativas y constitucionales.

${ }^{61}$ Sobre la materia ver, Pinto, Mónica. (1997). Amaya Villarreal, Álvaro Francisco. (2005), pp. 337 380 .

${ }^{62}$ De Vergottini, Giuseppe. (2011), pp. 71-86.

${ }^{63}$ SuXe, Hervé. (2007), p. 158. 
El fin de este diálogo es intercambiar perspectivas sobre el sentido y alcance de las disposiciones convencionales entre un emisor y un receptor, cada uno de los jueces nacionales ordinarios o constitucionales por una parte, y la Corte Interamericana de Derechos Humanos, por otra, ejercen en cada turno las dos funciones.

Objetivar el diálogo significa que cada uno de los actores del mismo, son co-responsables de los términos del intercambio de posiciones, establecen objetivos, cada uno a su manera, precisan los términos de sus propias contribuciones al diálogo, reconociendo siempre que, en último término, corresponde a la Corte Interamericana determinar la última palabra, ya que tiene las competencias para ello en los artículos 67 a 69 de la CADH.

El diálogo de jueces permite al juez interno deshacerse de las obligaciones que pesan sobre él, de su subordinación a la ley nacional ya que, en virtud de los derechos asegurados convencionalmente puede inaplicar la norma interna, mejor dicho, el juez nacional podrá aplicar preferentemente el derecho asegurado convencionalmente cuando la ley interna establezca un estándar más bajo que el que exige el derecho convencional, aplicando siempre la norma interna o convencional que mejor proteja el derecho fundamental en juego o aquella que lo limite o restrinja menos de acuerdo al principio favor persona o pro homine y el principio de progresividad, así el juez nacional puede censurar las normas contrarias a la norma convencional. Por otra parte, el juez nacional podrá aplicar preferentemente la norma interna cuando establezca un estándar más alto que la norma convencional. Asimismo, podrán debatir sobre la interpretación del corpus iuris interamericano con la Corte Interamericana, teniendo presente, en todo caso, que la interpretación de la Corte Interamericana en la resolución del caso será obligatoria para el Estado Juez cuando ésta resuelva el asunto y ponga fin al diálogo.

Asumiendo el corpus iuris interamericano y los métodos interpretativos de los derechos se pueden establecer las bases de un diálogo, donde el juez interno se encuentra ante la posibilidad de proponer interpretaciones de la CADH y del corpus iuris interamericano que enriquezcan la visión del mismo, ya que dichas cuestiones no han sido aún abordadas por la CIDH, no existiendo pronunciamientos jurisdiccionales acerca de ellas. El juez nacional puede iniciar un diálogo en dirección del juez interamericano, el que luego puede ser retomado por este último, como ya señala Frederic Sudre, analizando el dialogo entre los jueces nacionales europeos y el TEDH ${ }^{64}$.

${ }^{64}$ SUDRE, F. (2004), p. 218. 


\subsection{Las modalidades de interpretación del corpus iuris interamericano por parte del juez nacional en el diálogo con la CIDH}

En este diálogo interjurisdiccional a partir de la judicatura ordinaria o constitucional interna del Estado Parte con la Corte Interamericana de Derechos Humanos, el juez nacional puede desarrollar diversas hipótesis interpretativas ${ }^{65}$ : A) la interpretación extensiva; B) la interpretación innovadora; C) la interpretación correctiva; D) la interpretación receptiva; E) la interpretación neutralizadora y F) interpretación discordante

\section{A) La interpretación extensiva}

El juez nacional puede desarrollar una interpretación extensiva la que puede llevarlo más allá de los alcances de la interpretación desarrollada por la $\mathrm{CIDH}$. El juez nacional puede asumir así una interpretación de la Convención que favorece una ampliación del campo de aplicación del derecho garantizado y, en consecuencia, sometiendo al respeto de este derecho, situaciones que han sido analizadas con un alcance menor hasta el presente por la jurisprudencia de la CIDH en aplicación del corpus iuris interamericano ${ }^{66}$.

Se concreta así un intercambio bilateral o multilateral mediante uno o más tribunales nacionales ordinarios o constitucionales en el entrelazamiento de propósitos en un mismo coloquio, que reposa sobre un reforzamiento de cada uno de los tribunales participantes de los Estados Partes de la Convención y la Corte Interamericana en su convicción de construir soluciones mediante un esfuerzo común dialogado.

El Tribunal Constitucional chileno ha realizado esta interpretación extensiva a partir del derecho al nombre contenido en el artículo 18 de la $\mathrm{CADH}$, artículo 24.2 del PIDCyP de UN y artículo 7 párrafos 1 y 2 de la Convención de Derechos del Niño para desarrollar interpretativamente el derecho a la identidad como derecho esencial, el que luego utiliza como parámetro de control de constitucionalidad para enjuiciar la inaplicabilidad por inconstitucionalidad del artículo 206 del Código Civil

"La afirmación precedente se concilia perfectamente con el criterio sostenido por esta Magistratura en el sentido de que el derecho a la identidad personal está

${ }^{65}$ Ver SUDRE, Frédéric (2007), pp. 8-9.

${ }^{66}$ En un sentido similar para el sistema europeo, ver MAdeleine, Colombine. (2007), p. 132. 
estrechamente ligado a la dignidad humana, en cuanto valor que, a partir de su consagración en el artículo $1^{\circ}$, inciso primero, de la Ley Suprema, constituye la piedra angular de todos los derechos fundamentales que la Ley Suprema consagra. Asimismo, que aun cuando la Constitución chilena no reconozca, en su texto, el derecho a la identidad, ello no puede constituir un obstáculo para que el juez constitucional le brinde adecuada protección, precisamente por su estrecha vinculación con la dignidad humana y porque se encuentra protegido expresamente en diversos tratados internacionales ratificados por Chile y vigentes en nuestro país (Sentencia Rol No 834, considerando 22);".

\section{B) La interpretación innovadora}

El juez nacional, mediante la interpretación innovadora puede abordar algunos derechos contenidos en la $\mathrm{CADH}$, sobre los cuales la Corte Interamericana puede no haber emitido pronunciamientos hasta el presente. En tal hipótesis, el juez nacional se enfrenta a problemas en los que deberá crear una solución jurisprudencial inédita considerando el corpus iuris interamericano, en los que puede liberarse de la servidumbre de la ley nacional realizando una interpretación de la norma convencional inédita, con la cual franquea el derecho legislado interno y abre la vía al diálogo con el juez de la CIDH, a través de un diálogo ascendente, el cual queda suspendido hasta que la $\mathrm{CIDH}$ conociendo de un caso análogo confirme o revierta la decisión adoptada por el juez nacional.

La emancipación interpretativa del juez nacional llega a su máxima expresión cuando éste innova, cuando confrontado al silencio de la jurisprudencia de la $\mathrm{CIDH}$, censura una norma nacional bajo el fundamento directo de la $\mathrm{CADH}$, estableciendo una decisión fundada sobre una interpretación que el propone de la Convención. Así el juez nacional inicia un diálogo con el juez interamericano que puede ser potencial o efectivo con la Corte Interamericana.

A través de la interpretación convencional que realiza el juez nacional ordinario o constitucional, éste puede en su interpretación otorgar un alcance más amplio a los atributos que integran un derecho garantizado o determinar con mayor precisión el alcance de una limitación restrictiva de un derecho fundamental, como asimismo, incorporar métodos y enfoques interpretativos con fundamento en el derecho internacional de los derechos humanos.

Las soluciones innovadoras de la judicatura nacional podrán influir en la jurisprudencia futura de la CIDH, para lo que deberá esperarse que el juez in- 
teramericano conozca un caso similar al resuelto en los planos nacionales, por lo que el diálogo mientras ello no ocurra será sólo un diálogo potencial, si la $\mathrm{CIDH}$ considera la jurisprudencia nacional en un caso que ella conoce posteriormente el diálogo será entonces efectivo, ya sea aprobatorio o reprobatorio de la actuación de la judicatura nacional.

\section{C) La interpretación correctiva}

La interpretación correctiva es aquella en que los jueces nacionales sacan las consecuencias de una condena por la CIDH del Estado Parte, lo que genera un cambio en la jurisprudencia nacional, la que rectificará su jurisprudencia y practicará una interpretación conforme al derecho convencional conforme al fallo de la CIDH.

En el caso que la CIDH ya haya elaborado una línea jurisprudencial en la materia objeto del litigio, el juez nacional conociendo un caso igual en que debe aplicarse los mismos principios y ratio decidendi se conforma de buena fe a la jurisprudencia de la CIDH como estándar mínimo, corrigiendo la interpretación que hasta entonces había desarrollado en el ámbito nacional, sin esperar que la CIDH concrete una condena por violación de derechos humanos contra el Estado chileno, por responsabilidad de Estado juez, con las consiguientes consecuencias de sanciones y medidas reparatorias incluyendo el pago de indemnizaciones pecuniarias, las que eventualmente el Estado podría repetir haciéndola efectiva en contra de los jueces responsables, en virtud de la responsabilidad extracontractual contenida en el artículo 39 de nuestra Constitución.

El alineamiento de los jueces nacionales sobre la jurisprudencia de la Corte Interamericana constituye una garantía para evitar tanto como sea posible una condena de la $\mathrm{CIDH}$ por desarrollar el juez nacional una interpretación que no alcanza el estándar mínimo exigido por ella.

Esta es la conducta esperada de los jueces nacionales en virtud del mandato imperativo del artículo $5^{\circ}$ inciso $2^{\circ}$ de la Constitución y el cumplimiento prevalente de los artículos 1 y 2 de la Convención Americana sobre Derechos Humanos, además de las normas de interpretación de derechos contenidas en ella en su artículo 29, las que son derecho interno vinculante para el juez nacional, el cual debe asumir el principio interpretativo "pro homine" o "favor persona”, que es la clave básica de interpretación en materia de derechos fundamentales.

Adicionalmente, para desarrollar esta interpretación correctiva por parte de los jueces nacionales se encuentran las razones de derecho positivo internacional 
e interno, en virtud de los artículos 26, 27 y 31 de la Convención de Viena sobre Derecho de los tratados en armonía con el artículo 54 № 1 , inciso $5^{\circ}$ de nuestra Constitución, obligatorios para el juez nacional del cumplimiento de buena fe de las obligaciones internacionales en materia de derechos humanos, sin oponer obstáculos de derecho interno al cumplimiento de tales obligaciones. Todo ello sin perjuicio de los argumentos de prestigio, de imperativo de cumplimiento de deberes jurisdiccionales y de argumentos funcionales a considerar, entre estos últimos la inutilidad de multiplicar los contenciosos ante la judicatura interamericana y el riesgo de la condena por la CIDH, que obligará más temprano que tarde, igualmente a modificar la jurisprudencia y conformarse al seguimiento de la jurisprudencia de la Corte Interamericana. Así, los mensajes enviados por la Corte de San José, deben ser prudentemente oídos y comprendidos por los jueces nacionales e inducir los cambios prudentes y necesarios de líneas jurisprudenciales.

Así el juez nacional, de cualquier jurisdicción o instancia cuando conoce de un litigio o gestión judicial en la cual una sentencia de la Corte Interamericana ha determinado que la ley interna viola la Convención y los derechos humanos, se encuentra confrontado a una decisión, la de aplicar preferentemente el derecho humano y la convención en virtud de las obligaciones constitucionales del artículo $5^{\circ}$ inciso $2^{\circ}$ y el artículo $54 \mathrm{~N}^{\circ} 1$, inciso $5^{\circ}$, de la Constitución en armonía con los artículos 1.1, 2 y 29 de la Convención Americana de Derechos Humanos, siguiendo los estándares mínimos exigidos por la CIDH, o desafiar a la Corte Interamericana y al propio derecho constitucional chileno, aplicando la ley nacional que se encuentra por debajo de los estándares mínimos del corpus iuris interamericano y que el legislador aún no ha modificado, sabiendo de antemano que ello arriesga una condena del Estado chileno por vulneración de derechos humanos en virtud de la actuación del Estado juez.

La respuesta de los tribunales ordinarios chilenos ha sido aplicar el estándar mínimo fijado por la CIDH después de la Sentencia de la última tentación de Cristo, no aplicando más censura judicial previa a través de medidas cautelares o sentencias en materia de libertad de expresión, además del acatamiento del Estado en el caso específico, cerrando el diálogo mediante la modificación del inciso final del artículo 19 No 12 de la Constitución.

Ello se repite en el caso Almonacid Arellano vs. Chile, donde la Sala Penal de la Corte Suprema aplica es estándar fijado por la CIDH en el caso estableciendo la no aplicación de amnistía ni prescripción a crímenes desarrollados por agentes del Estado como parte de una política institucional de eliminación física de 
enemigos políticos, determinando investigación, determinación de responsables, sanción penal y reparación, desde diciembre de 2006 en que se inaugura la línea jurisprudencial. La decisión de la Corte Suprema de transferir la competencia a la jurisdicción militar y la decisión del Segundo Juzgado Militar de Santiago de amnistiar, confirmada por la Corte Marcial, con la sentencia de la Corte Interamericana quedaron sin efecto, lo que muestra los efectos de la sentencia de la CIDH sobre la cosa juzgada de los tribunales nacionales sobre las resoluciones de la Corte Suprema y de los tribunales militares, pudiendo concluirse que no hay cosa juzgada en Chile hasta que no transcurran los plazos para que el caso respectivo pueda ser examinado por vía del amparo interamericano y se pronuncie la Corte Interamericana de Derechos Humanos.

En el caso específico analizado, el Ministro en Visita Extraordinaria de la Corte de Apelaciones de Rancagua, señor Carlos Moreno Vega, remite oficio para que el Segundo Juzgado Militar se inhiba del conocimiento de los hechos, el juez militar desarchiva los autos y los envía al Ministro Instructor Carlos Moreno, no dando lugar a la inhibitoria, trabándose contienda de competencia ante la Corte Suprema, la que omite pronunciarse sobre el conflicto de competencia y ordena remitir los autos al Ministro Instructor, el cual dicta resolución en virtud del artículo 68 de la CADH que obliga al Estado a cumplir la sentencia Almonacid Arellano, concretando la tramitación de la causa, siendo acusado en ella y condenado el oficial de Carabineros Raúl Hernán Neveu Cortesi en sentencia de 18 de agosto de 2011, en causa Rol No 40.184, a cinco años de presidio menor en su grado máximo, sentencia que se encuentra apelada ante la Corte de Apelaciones de Rancagua.

Asimismo en virtud de los casos Palamara y Almonacid Arellano, el Estado chileno cierra el diálogo con la $\mathrm{CIDH}$, con la modificación de la judicatura militar, la que termina con la exhorbitación de sus competencias reprochada por dicha Corte, reduciéndose la competencia de la jurisdicción militar solamente al juzgamiento de militares en servicio activo en el desarrollo de sus funciones militares.

Cada vez más la actuación prudente y de buena fe lleva a los jueces nacionales y a los otros órganos estatales Estado constituyente o legislador o Estado administrador a cumplir los estándares fijados por la CIDH y adecuar los ordenamientos jurídicos y constitucionales, alineándose con los estándares mínimos exigidos por el corpus iuris interamericano, sin perjuicio de casos excepcionales y aislados que aún se resisten a aplicar preferentemente este cuerpo jurídico con preferencia al derecho interno, lo que lleva a la senda segura de la condena 
del respectivo Estado Parte por la Corte Interamericana, con la consiguiente obligación de reparación en cumplimiento obligatorio de la sentencia de la Corte de San José, de acuerdo al artículo 68 de la CADH, salvo que se opte por abandonar el sistema interamericano de Derechos Humanos con todas sus consecuencias jurídicas, políticas y económicas, como ya lo hizo Barbados en su oportunidad, como intentó hacerlo Perú bajo el régimen de Fujimori, lo que fue revertido por el gobierno democrático posterior.

\section{D) La interpretación receptiva}

La interpretación receptiva de los jueces nacionales es aquella que se conforma a la ratio decidendi de las sentencias de condena de otros estados partes de la CADH por violación de ésta, o de principios establecidos en Opiniones Consultivas, tomando la iniciativa de asumir tales principios en su propia jurisprudencia, sin esperar que el Estado Parte sea condenado por violación del corpus iuris interamericano para hacerlo, como asimismo ampliando los atributos y garantías de los derechos fundamentales en base a los estándares mínimos fijados por la CIDH, dejando así su huella sobre el derecho interno, completándolo o aplicando preferentemente el derecho convencional, sorteando las situaciones de inconvencionalidad o estableciendo estándares de interpretación de derechos no contenidos explícitamente en el derecho interno como el principio favor persona o el principio de progresividad, el de razonabilidad $\mathrm{y}$ de proporcionalidad, entre muchos otros.

Puede señalarse que este es el camino desarrollado por el Tribunal Constitucional chileno cuando aplica el postulado o principio pro homine o favor persona, desarrollado por la Opinión Consultiva No 5/1985 de la CIDH, en aplicación del artículo 29 de la CADH, en la sentencia 1361-09, su sentencia sobre la LEGE de 2009:

"Que, por otra parte, en el ejercicio de sus funciones, este Tribunal debe buscar aquella interpretación que se avenga mejor con el respeto de los derechos constitucionales. Así lo ha sostenido: 'En tal sentido, parece ineludible tener presente el principio "pro homine" o "favor libertatis" definido en la jurisprudencia de la Corte Interamericana de Derechos Humanos de la siguiente forma: "Entre diversas opciones se ha de escoger la que restringe en menor escala el derecho protegido (...) debe prevalecer la norma más favorable a la persona humana" (Opinión Consultiva 5, 1985);' (Rol No 740);"67.

${ }^{67}$ Sentencia del Tribunal Constitucional, Rol No 1361-09, de trece de mayo de dos mil nueve, considerando $73^{\circ}$. 
Esta perspectiva también la concreta el Tribunal Constitucional en rol No 567 de 2010 sobre el caso sobre inconstitucionalidad del Movimiento Patria Nueva Sociedad, asume la jurisprudencia de la CIDH en el considerando 35, que considera la libertad de expresión como "un medio para el intercambio de ideas e informaciones entre las personas, por lo que comprende además del derecho a comunicar, el derecho a conocer opiniones, relatos y noticias; señalando que el derecho a conocer la información y opinión ajena tiene tanta importancia como el derecho a difundir la propia", invocando a tal efecto la sentencia de la CIDH en el caso Palamara Iribarne vs. Chile, en su sentencia de 22 de noviembre de 2005.

\section{E) La interpretación neutralizadora.}

La interpretación neutralizadora de derecho interno, es definida por Sudre ${ }^{68}$ como una estrategia de evadir, eludir o de evitar, tendiente a neutralizar la interpretación del corpus iuris interamericano o de la Convención Europea de Derechos Humanos o la jurisprudencia de la CIDH o del TEDH, creando, por una interpretación forzada del derecho nacional, una reescritura de la ley o una especie de mutación, una relación de adecuación entre el derecho interno y la norma interamericana o europea en su caso.

La interpretación neutralizante permite al juez nacional, a falta de suscribir realmente la solución determinada por la jurisprudencia de la $\mathrm{CIDH}$, de adquirir por una aplicación puramente formal una cierta autonomía en la aplicación de la Convención. Lo que muestra una falta de sinceridad por una de las partes que participa del diálogo, constituyendo como explica el profesor Sudre, una estrategia de evasión o elusión tendiente a neutralizar la interpretación "(...) creando, por una interpretación un poco forzada del derecho nacional, es decir, por una reescritura de la ley, una relación de adecuación entre el derecho interno y la norma europea" ${ }^{69}$ o en nuestro caso interamericana, la que es difícil de determinar en algunos casos, ya que hay una diferencia sutil entre una mala aplicación de buena fe del corpus iuris interamericano, cuando no hay cosa interpretada de la Corte Internacional competente o cuando hay

${ }^{68}$ Sudre, Frederic. (2004), p. 210.

69 SUDRE. Frederic. (2004), p. 210. 
una mala aplicación consciente que simplemente ignora la cosa interpretada de la Corte respectiva, en abierto desafío a la misma cuando no puede ignorar la existencia de la misma.

La interpretación neutralizante busca esconder la reivindicación de un margen de apreciación o constituye una maniobra que permite al juez nacional escaparse de aplicar la jurisprudencia de la CIDH, logrando con ello dos objetivos ${ }^{70}$. El primero, validar la legislación nacional respecto del derecho garantizado convencionalmente tal como es interpretado por el juez nacional. Así, es el contenido o atributos del derecho y sus garantías como estándar mínimo el que es neutralizado, siendo algunos de tales atributos o garantías borrados para permitir preservar artificialmente el derecho nacional. El segundo, es la de pretender, por el juez nacional, el beneficio de un cierto margen de apreciación en una materia que la $\mathrm{CIDH}$ no reconoce ni considera margen de apreciación.

El estudio de la interpretación neutralizante nos sitúa en el caso en que la solución desarrollada por el juez nacional, no aplica la solución que se desprende objetivamente de la interpretación auténtica de la disposición convencional efectuada por la CIDH.

Consideramos que este es el caso de la sentencia del Tribunal Constitucional chileno en el caso Aaron Vásquez, en que la sentencia busca neutralizar el sentido y alcance del derecho al recurso establecido en el artículo 8.2 literal h) de la Convención Americana de Derechos Humanos, considerando que dicho recurso podría ser un recurso extraordinario como el de queja, aun cuando éste no pueda revisar los hechos, alejándose del estándar fijado por la Corte Interamericana en el caso Herrera Ulloa con Costa Rica, en el cual precisa que este derecho al recurso es a un recurso ordinario y que revise hechos y derecho, tesis que también sostienen los órganos encargados de interpretar y aplicar el artículo 14 del Pacto Internacional de Derechos Civiles y Políticos de Naciones Unidas. En esta sentencia del Tribunal Constitucional, el voto minoritario de algunos ministros reprochan a la mayoría no hacerse cargo de la interpretación y alcance del derecho a revisión de la sentencia penal ya fijado por la Corte Interamericana en Herrera Ulloa con Costa Rica.

${ }^{70}$ Dubors, Julien (2007). "La neutralisation. Dialogue des juges et interprétation neutralisante". En VV.AA. (2007). Le dialogue des juges. Institut de Droit des Droits del L'Homme. Cahiers de L'IDEDH No 11. Université de Montpellier I. Faculté de Droit. Montpellier, pp. 75-76. 
F) La interpretación francamente discordante del tribunal nacional de la normativa convencional y la interpretación de aquella realizada por la CIDH

Un tribunal nacional ordinario o constitucional puede diferir del alcance o interpretación dado por la CIDH en un caso determinado resuelto por ésta. En tal sentido, la jurisdicción interna del Estado considera que la resolución de la CIDH constituye una interpretación que considera incorrecta ya que no evalúo correctamente la norma de derecho interno u olvido ponderar adecuadamente otro derecho o un atributo determinado de otro derecho que debe considerarse. El tribunal nacional en un nuevo caso sobre la misma materia, expresa su desacuerdo con la CIDH razonadamente, explicando los motivos del desacuerdo en el respectivo fallo, concretando un diálogo ascendente con la CIDH. En el caso chileno, no existen fallos de este tipo hasta el presente.

La Corte Interamericana podrá reexaminar la cuestión controvertida si el caso llega a la jurisdicción interamericana o en otro fallo sobre una materia similar, concretándose así un nuevo dialogo franco, leal y de buena fe. Sin embargo, la resolución del caso por la Corte Interamericana vinculará al tribunal nacional en forma obligatoria.

\section{El FIN DEL DIÁLOGO INTERJURISDICCIONAL ENTRE TRIBUNALES NACIONALES Y CORTE INTERAMERICANA}

Una primera forma en que termina el diálogo entre tribunales nacionales y Corte Interamericana se concreta cuando esta última en la misma materia en que se ha producido el desacuerdo de interpretación y aplicación de la norma convencional resuelve el desacuerdo mediante su sentencia que tiene carácter vinculante y generando obligación de resultado para el respectivo Estado Parte, la que será supervigilada por la CIDH hasta su completo cumplimiento.

Al diálogo interjurisdiccional entre jueces internos y Corte Interamericana se le pone término también de una segunda forma, cuando el Estado Parte a través de su poder constituyente o a través del legislador, confrontado una disposición considerada inconvencional por la $\mathrm{CIDH}$, incluso pudiendo estar ya descartada su fuerza vinculante por una aplicación preferente de la norma convencional o una interpretación favor persona por el juez nacional, decide modificar la norma jurídica interna en el sentido de adecuarla al estándar del corpus iuris interamericano y a la jurisprudencia de la CIDH o derogar dicha normativa jurídica, como ocurrió en Chile con la modificación de la Constitución, artículo 19 No 12, inciso final, como consecuencia de la sentencia 
Olmedo Bustos y otros vs. Chile; cuando el legislador modificó la legislación sobre justicia militar como consecuencia de las sentencias "Palamara Iribarne vs. Chile" y "Almonacid Arellano y otros vs. Chile", cuando crea una nueva norma constitucional, nueva legislación e instituciones como el Consejo para la Transparencia en el ámbito del derecho de acceso a la información pública y transparencia, a propósito del caso "Claude Reyes y otros vs. Chile"; o cuando acelera la aprobación de la ley anti discriminación después del fallo "Atala y niñas vs. Chile”, para señalar algunos ejemplos nacionales.

$\mathrm{LaCIDH}$ en base al corpus iuris interamericano va construyendo el patrimonio jurídico común mínimo de los Estados Americanos. Las concepciones comunes se van desarrollando y consolidando, contribuyendo a ello la jurisprudencia de las jurisdicciones de los estados partes del sistema interamericano.

Es a partir del examen de la evolución de las jurisprudencias nacionales que la CIDH desarrolla la interpretación evolutiva de la CADH. Ella lo hace teniendo en cuenta los cambios sociales percibidos por los jueces internos en la estructura y concepción de la familia, el matrimonio, el transexualismo, sobre la vida humana (su inicio y su término), para sólo señalar algunos de ellos.

La efectividad de las decisiones de la CIDH reposa entre otros aspectos, en la voluntad cooperadora leal de los jueces nacionales. Aun cuando la decisión no sea en un caso concreto de un Estado Parte, la jurisprudencia de la CIDH constituye para los jueces de todos los estados parte una fuente de inspiración, como asimismo constituye un argumento de autoridad en que apoyar las decisiones jurisdiccionales nacionales.

$\mathrm{LaCIDH}$ al igual que la CEDH puede sancionar la lentitud excesiva en el cumplimiento de sus sentencias, en el caso de la Corte Interamericana ello lo concreta por medio del no desasimiento del caso con la sentencia y la supervigilancia del cumplimiento de las mismas, hasta que ellas se cumplen plenamente por parte del Estado infractor, como asimismo, tanto la CIDH como el TEDH pueden exponer al Estado Parte a una nueva condena ${ }^{71}$.

\section{EL IMPACTO DEL CORPUS IURIS INTERAMERICANO EN EL DERECHO INTERNO}

En una aproximación formal, la relación entre CADH y el corpus iuris interamericano con el ordenamiento constitucional puede ser interpretado desde

\footnotetext{
${ }^{71}$ Ver en el caso europeo CEDH, 29 de noviembre de 1991, Vermeire c/Bélgique, A 214-C párrafos 25 y ss. 
el esquema de teoría de las fuentes y el criterio de resolución de conflictos de normas.

El tratado es fuente infraconstitucional en virtud del análisis de conformidad de la Constitución con el tratado internacional que realiza el Tribunal Constitucional conforme al artículo 93 No 1 y No 3 de la Constitución, pero a su vez, es norma de aplicación preferente una vez incorporado al ordenamiento jurídico en forma válida, de acuerdo a la regla constitucional prevista en el artículo 54 No 1 , inciso 5०: "Las disposiciones de un tratado sólo podrán ser derogadas, modificadas o suspendidas en la forma prevista en los propios tratados o de acuerdo a las normas generales de derecho internacional", por lo cual, el tratado prevalece sobre las leyes internas, salvo que estas últimas contengan un estándar más alto de protección de los derechos que aquel que concreta el corpus iuris interamericano, aplicando el principio favor persona.

En tal perspectiva, el juez ordinario o especial, con competencia sobre el fondo de la materia analizada, dispone siempre de la potestad para aplicar preferentemente la norma convencional sobre los preceptos legales que sean contrarios a ella, de lo contrario genera responsabilidad internacional del Estado y vulnera los artículos 26 y 27 de la Convención de Viena sobre Derecho de los Tratados que sin dejar de ser norma internacional son norma de derecho interna al incorporarse al ordenamiento jurídico mediante la ratificación de dicha Convención. El Tribunal Constitucional en sentencia Rol No 804, considerando $15^{\circ}$, ha precisado que, ante la existencia de un conflicto entre un tratado y una ley, sin que exista un problema de constitucionalidad de esta última, el tema queda dentro de las atribuciones de los jueces ordinarios los que deben calificar y decidir sobre la materia: "No existe, de esta manera, un problema de constitucionalidad-oposición sustantiva de la ley a la Constitución-, sino de contraste entre un tratado internacional vigente y una ley nacional, que corresponde calificar y decidir al juez de la instancia". El Tribunal Constitucional en la misma sentencia Rol No 804, afirma en su considerando 50: "Que, indudablemente, el intérprete en general y el juez en particular debe realizar los mayores esfuerzos, dentro del ámbito constitucional, para procurar cumplir de buena fe las disposiciones y los fines del tratado, conciliando sus disposiciones con otras normas del Derecho Interno, prefiriendo aquellas interpretaciones que armonicen los derechos y obligaciones que del tratado internacional se derivan con el orden jurídico chileno" ${ }^{\prime \prime}$.

${ }^{72}$ Sentencia Tribunal Constitucional Rol No 804-07-INA, de 28 de diciembre de 2007. 
En una aproximación material o sustancial y no meramente formal, que es la que exige el artículo $5^{\circ}$ inciso $2^{\circ}$ de la Constitución chilena, el foco se pone en un enfoque intrínseco al contenido de la norma, con la consiguiente adopción del método propio de la teoría de la interpretación de los valores. Desde esta perspectiva, se debe asegurar, promover y garantizar los derechos de las personas a través de la consideración de los atributos de tales derechos que amplían la protección de ellos conforme al principio favor persona especialmente si no están formalmente previstos en el texto constitucional, como aquellos que se pueden deducir de valores y principios constitucionales (los derechos implícitos), en plena armonía con el artículo 29 literal c) de la $\mathrm{CADH}$, disponiendo este último que "Ninguna disposición de la presente Convención puede ser interpretada en el sentido de: c) excluir otros derechos y garantías que son inherentes al ser humano o que se derivan de la forma democrática representativa de gobierno"; como asimismo de otros derechos esenciales o humanos cuyos atributos y garantías se encuentran contenidos en el derecho convencional internacional, los que ingresan materialmente al texto constitucional en la medida que tales derechos limitan el ejercicio de la soberanía al tenor del artículo $5^{\circ}$ inciso $2^{\circ}$ de la Constitución y fijan un estándar mínimo obligatorio más elevado que la norma jurídica nacional.

De esta manera, el juez o tribunal de justicia abre la competencia respecto del tratamiento de tutela o protección de los derechos, asumiendo el rico inventario de los instrumentos y soluciones considerados por el derecho convencional de derechos humanos, ratificado y vigente, interpretado en clave de los principios o postulados "favor persona" y de "progresividad", contenidos en las normas de interpretación de derechos del artículo 29 de la CADH que son parte de nuestro derecho interno, con aplicación preferente frente a las normas internas que colisionan con ellas, posibilitando la desaplicación de la norma interna que contravenga los estándares mínimos de protección de los derechos humanos determinado en el corpus iuris interamericano interpretado por la CIDH.

En esta perspectiva, el Tribunal Constitucional en virtud de los artículos $5^{\circ}$ inciso $2^{\circ}, 6^{\circ}, 7^{\circ}$ y 93 de la Constitución; todo ello complementado e interrelacionado con los artículos 1, 2, 29, 63 y 67 al 69 de la CADH y atendiendo al principio pro homine o favor persona, en relación a atributos de derechos esenciales o fundamentales contenidos en el corpus iuris interamericano u otras convenciones vinculantes para el Estado de Chile, debe concretar un control de constitucionalidad que incorpore los estándares mínimos sobre atributos de los derechos y garantías asegurados convencionalmente en cuanto Estado 
Juez que está vinculado a asegurar y garantizar tales derechos, no sólo por exigencia de los artículos $1^{\circ}$ y $2^{\circ}$ convencionales, sino también como exigencia del artículo $5^{\circ}$ inciso $2^{\circ}$ de la Constitución, en una interpretación leal con su objeto y fin, agregando a ello los principios de ius cogens pacta sunt servanda y bonna fide positivados en los artículos 26 y 31 de la Convención sobre Derecho de los Tratados y el artículo 27 del mismo que exige a los estados partes no poner obstáculos de derecho interno al cumplimiento de las obligaciones internacionales, normas que son, además de derecho interno al incorporarse al ordenamiento jurídico y ser de preferente aplicación respecto de los preceptos legales, en conformidad al artículo $54 \mathrm{~N}^{\circ} 1$, inciso $5^{\circ}$ de la Carta Fundamental.

Ello implica aplicar por el Tribunal Constitucional dichos estándares mínimos de derechos fundamentales según el principio favor persona en el ejercicio de todas sus competencias determinadas por el artículo 93 de la Constitución. Tal perspectiva lo habilita para determinar la inaplicabilidad de preceptos legales mediante su competencia del artículo 93 No 6 de la Constitución, o expulsar normas legales del ordenamiento jurídico en virtud de acciones de inconstitucionalidad conforme a su competencia determinada por el artículo 93 No 7 de la Constitución, cuando dichas disposiciones legales en general o su aplicación a casos concretos controvierten dicho estándar mínimo del bloque de derechos fundamentales, como asimismo, para determinar la inconstitucionalidad de potestad administrativa de acuerdo con el artículo 93 No 9 y 19 o en el enjuiciamiento de autos acordados de los tribunales superiores de justicia o del Tribunal Calificador de Elecciones, de acuerdo al artículo 93 No 2.

Asimismo, todos los jueces y tribunales ordinarios y especiales del país, en los asuntos de su competencia y en los procesos y gestiones judiciales que conozcan, de acuerdo a los respectivos procedimientos, son guardianes y garantes de los derechos humanos, debiendo ejercer el control de convencionalidad, en virtud del cual tienen la potestad de aplicar preferentemente los atributos y garantías de los derechos fundamentales asegurados convencionalmente por sobre las normas de derecho interno que infrinjan o contravengan los estándares mínimos de los derechos fundamentales garantizados convencionalmente, en virtud de la aplicación preferencial del derecho convencional internacional de derechos humanos y a la aplicación de los preceptos del derecho interno conforme al derecho convencional de derechos humanos y a la Constitución, en virtud de las obligaciones jurídicas vinculantes contenidas en el artículo $5^{\circ}$ 
inciso $2^{\circ}$ de la Constitución y los artículos artículos 1, 2, 29, 62, 63, 64 y 67 a 69 de la $\mathrm{CADH}$, sólo para efectos de inaplicar las normas de derecho interno y aplicar preferentemente el estándar mínimo de los atributos y garantías de los derechos fundamentales exigido por el derecho convencional internacional vinculante para el Estado de Chile, conforme al postulado o principio "favor persona", respetando el contenido esencial de los derechos fundamentales (artículo 19 No 26), como asimismo, aplicando el principio de razonabilidad y de proporcionalidad a toda norma interna restrictiva o limitadora de derechos humanos, con una adecuada ponderación destinada a optimizar el ejercicio de los derechos, además de considerar las limitaciones o restricciones legales de los derechos en su "estricta necesidad en una sociedad democrática".

Los tribunales ordinarios y especiales no pueden declarar la invalidez de las disposiciones legales que vulneran el estándar mínimo de protección de los derechos humanos, pero tienen la potestad para requerir al Tribunal Constitucional, cuando consideren necesaria la expulsión de una norma del ordenamiento jurídico interno que vulnera los estándares mínimos de aseguramiento de derechos y garantías de carácter convencional, en virtud de lo dispuesto en el artículo 93 No 7 de la Constitución, que le atribuye a este último dicha competencia en forma exclusiva, teniendo presente que se requiere que previamente el mismo Tribunal Constitucional haya declarado inaplicable por inconstitucional el precepto legal cuestionado, por el o los mismos vicios previamente considerados en la sentencia de inaplicabilidad.

Los órganos jurisdiccionales deben entender y aplicar las normas de la manera más idónea para facilitar la solución de conflictos y el acceso a tribunales en aras de otorgar protección judicial efectiva de los derechos fundamentales y un efectivo y real derecho a la jurisdicción, en virtud de lo dispuesto en los artículos $6^{\circ}, 7^{\circ}, 19$ No 3 y 76 de la Constitución en armonía con los artículos 8 y 25 de la CADH y 14 del PIDC y P de Naciones Unidas, considerando la aplicación de los principios pro actione, effet utile y iura novit curia, siendo suficiente el conocimiento de los hechos básicos para determinar el derecho aplicable al caso, excluyendo cualquier interpretación o aplicación del derecho que anule o prive de eficacia a los derechos y garantías constitucionales, entre ellas las acciones constitucionales protectoras de derechos en armonía con el artículo 25 de la Convención Americana sobre Derechos Humanos.

Los órganos, autoridades y funcionarios del Estado con competencias distintas de las jurisdiccionales, como son el Estado legislador (el poder constituyente instituido, el poder legislativo), el Estado administración (gobierno y la 
administración, los órganos administrativos de control de juridicidad), deben interpretar y aplicar el derecho interno de conformidad con la Constitución y los tratados internacionales ratificados y vigentes, en una perspectiva interpretativa favor persona.

\section{El CONTROL DE CONVENCIONALIDAD EN LA PRAXIS DEL TRIBUNAL}

\section{CONSTITUCIONAL CHILENO}

En el presente acápite realizaremos una presentación de las formas que ha adoptado el diálogo entre el Tribunal Constitucional chileno y la Corte Interamericana de Derechos Humanos en el periodo 2006-2011, aplicando las distintas modalidades de interpretación reseñadas en el punto 3.1 de este artículo, que implica el uso de la interpretación correctiva, la interpretación receptiva, la interpretación innovadora y la interpretación neutralizadora. El Tribunal Constitucional no ha utilizado la interpretación extensiva, otorgándole a los derechos asegurados convencionalmente un alcance mayor que el que les ha fijado la jurisprudencia de la $\mathrm{CIDH}$, como tampoco ha concretado la interpretación discordante, la que implica necesariamente explicitar las razones y principios jurídicos que llevan al juez nacional a discrepar de la interpretación y aplicación de los preceptos convencionales que realiza la Corte Interamericana de Derechos Humanos.

\subsection{El diálogo del Tribunal Constitucional con la Corte Interamericana en} perspectiva de interpretación correctiva: El caso Movimiento Patria Nueva Sociedad, Rol No 567 de 2010; y acceso a la información pública, Rol No 1723-10 INA/ 1810-10 INA acumulados de fecha 21 de junio de 2011

\subsubsection{Requerimiento de parlamentarios y otros para que se declare la} inconstitucionalidad del Movimiento Patria Nueva Sociedad. (rol No 567 de 2010). Uso de la jurisprudencia de la CIDH en materia de libertad de opinión e información, además de enfoques interpretativos del TEDH

En esta sentencia pronunciada a requerimiento de algunos parlamentarios, autoridades locales y dirigentes sociales, se busca por parte de los requirentes la determinación de inconstitucionalidad de diversos movimientos políticos Movimiento Patria Nueva Sociedad, Instituto de Metapolítica NS, Vanguardia Nacional Chilena, Martillo del Sur, Camisas Pardas, Estandarte Hitleriano, Movimiento Nacional Socialista de los Trabajadores, Patriotas, Juventud Nacio- 
nalista Obrera, Chile Imperial y Nueva Unión, considerándolos movimientos nacistas o facistas. Luego los requirentes modificaron el requerimiento y lo dirigieron sólo contra el Movimiento Patria Nueva Sociedad por ser un movimiento nacional socialista, pronunciándose la sentencia solamente respecto de este último movimiento político ${ }^{\left({ }^{73}\right)}$.

El Tribunal Constitucional rechazará el requerimiento en su sentencia, considerando que no hay elementos de prueba que declarar la inconstitucionalidad del Movimiento Patria Nueva Sociedad.

Dentro de los razonamientos realizados por el Tribunal Constitucional en el análisis del caso, determinándose que nuestro sistema constitucional no asume la concepción de la democracia militante, sino la de una democracia pluralista, que asegura las distintas corrientes de expresión ideológica, garantizando por tanto la libertad de expresión.

El Tribunal Constitucional asume la jurisprudencia de la CIDH en el considerando $35^{\circ}$, que considera la libertad de expresión como "un medio para el intercambio de ideas e informaciones entre las personas, por lo que comprende además del derecho a comunicar, el derecho a conocer opiniones, relatos y noticias; señalando que el derecho a conocer la información y opinión ajena tiene tanta importancia como el derecho a difundir la propia”, invocando a tal efecto la sentencia de la CIDH en el caso Palamara Iribarne vs. Chile, en su sentencia de 22 de noviembre de 2005.

El Tribunal Constitucional determinará que conforme a la jurisprudencia de la CIDH no puede limitarse la expresión de ideas, "aunque irriten, alarmen, sorprendan o inquieten a las autoridades, como lo han señalado el Tribunal Europeo de Derechos Humanos (Parti Communiste Unifié de Turquie et autre c. Turquie, p. 43, y Refah Partisi et autres c. Turquie, p. 89) y la Corte Interamericana de Derechos Humanos".

Luego, el Tribunal Constitucional en el considerando $41^{\circ}$ de la sentencia, refiriéndose a las normas que sancionen la apología del odio, asumiendo también los estándares de la CIDH fijados en la sentencia Castillo Petruzzi y otros vs. Perú, precisa "que en la elaboración de los tipos penales es preciso utilizar términos estrictos y univocos, que acoten claramente las conductas punibles, dando pleno sentido al principio de legalidad penal" (Caso Castillo Petruzzi y otros, p. 121). Agregando que la ambigüedad de la ley podría "abrir el camino a toda suerte de arbitrariedades por parte de la autoridad, pues

${ }^{73}$ Sentencia del Tribunal Constitucional, Rol No 567-10 de 3 de junio de 2010 
tal como ha razonado este Tribunal "todos los conceptos que emplea la ley (con la excepción de las cifras, fechas, medidas y similares) admiten en mayor o menor medida varios significados" (considerando 40). Así el Tribunal Constitucional realiza una interpretación receptiva de la jurisprudencia de la $\mathrm{CIDH}$, mediante la asimilación de la ratio decidendi de la sentencia del caso Castillo Petruzzi y otros vs. Perú

A su vez, el Tribunal Constitucional invoca la jurisprudencia del Tribunal Europeo de Derechos Humanos respecto de las restricciones que pueden imponerse al derecho de asociación, "toda restricción de la libertad de asociación supone una interpretación estricta según el artículo 11 de la Convención Europea de Derechos Humanos, el cual deja a las autoridades nacionales un margen reducido de decisión. La declaración de una organización política como inconstitucional sólo podría tener lugar en los casos más graves, como última ratio, frente a un riesgo o amenaza real para la Constitución; (considerando $41^{\circ}$ ).

Hay aquí una referencia cruzada a un instrumento la Convención Europea de Derechos Humanos y a la interpretación de ella desarrollada por la Corte Europea de Derechos Humanos que es ajena al derecho aplicable en Chile, la que si bien es marginal en la jurisprudencia de nuestro Tribunal Constitucional es interesante de constatar. A pesar de la ausencia de pasarelas formales entre el sistema europeo de derechos humanos y el sistema interamericano y chileno, el diálogo de jueces se concreta, aún con dirección única, la recepción en Chile de la jurisprudencia del TEDH, la cual tiene la significación de conocer y aplicar las interpretaciones propuestas por otros jueces sobre un problema equivalente ${ }^{74}$ a aquel que los jueces constitucionales chilenos se confrontan, en el cual no hay jurisprudencia de la CIDH. Así informado el Tribunal Constitucional del sentido y alcance dado por el TEDH a un derecho en particular, la que si bien el tribunal Constitucional chileno puede desmarcarse ya que no lo vincula ni obliga, la asume y aplica en el caso del que conoce, por considerarla atingente, razonable y adecuada para resolver el caso del cual está conociendo. Así la jurisprudencia del TEDH es considerada por el Tribunal Constitucional chileno como un instrumento de un sistema ajeno al sistema jurídico nacional, pero en el cual puede apoyarse por decisión propia cuando evalúa una cuestión precisa y considera el derecho y la práctica internacionales como pertinentes. Así el elemento de comparación

${ }^{74}$ Hennebel, Ludovic (2007), p. 34. Ver también, Slaughter, A-M. (1994), p. 103. 
es utilizado para orientarse y apoyar la interpretación que realiza el Tribunal Constitucional, especialmente si los derechos protegidos son similares y los mecanismos y garantías equivalentes.

\subsubsection{Requerimiento de inaplicabilidad sobre Ley No 20.285}

sobre Acceso a Información Pública, en reclamo de ilegalidad radicado en Corte de Apelaciones de Santiago. Sentencia del Tribunal Constitucional Rol No 1723-10 INA/1810-10 INA acumulados de fecha 21 de junio de 2011. Estándar CIDH sobre publicidad y transparencia en gestión pública

En este caso, don Jorge Cabezas Villalobos y otros trabajadores de Televisión Nacional de Chile dedujeron una acción de inaplicabilidad por inconstitucionalidad respecto del artículo 10, literal h), de la Ley No 20.285, sobre Acceso a la Información Pública, en autos sobre reclamo de ilegalidad caratulados "Televisión Nacional de Chile con Consejo para la Transparencia", bajo el Rol No 945-2010.

A su vez, Francisco González H., en representación de Televisión Nacional de Chile, dedujo requerimiento de inaplicabilidad por inconstitucionalidad del mismo artículo 10, literal h), de la Ley No 20.285 y respecto del artículo 33, literal b) de la Ley de Transparencia de la Función pública y de Acceso a la Información de la Administración del Estado.

Se discute sobre la legalidad del acuerdo adoptado por el Consejo para la Transparencia que dispuso que TVN había vulnerado las normas sobre transparencia activa contenidas en el artículo 10, literal h, de la ley de Acceso a la Información Pública, ordenándosele informar las remuneraciones y otros beneficios de ejecutivos del Canal, en cuanto responsable de la dirección y administración superior de la empresa. Los ejecutivos requirentes plantean que la decisión del Consejo para la Transparencia afecta su derecho a la vida privada, dentro de cuyo ámbito se encuentra el monto de sus remuneraciones, protegido por el artículo 19 No 4 de la Constitución.

A su vez, TVN argumenta que la entrega de información requerida por el Consejo de la Transparencia, no satisface el artículo 19 No 21 de la Constitución, ya que se le somete a controles y deberes de información que son ajenos al derecho privado, sin que exista una justificación razonable para ello, vulnerando además la igualdad ante la ley, ya que la somete a controles diversos que los demás canales de televisión, considerando que la revelación de las remuneraciones de sus ejecutivos afecta la competitividad de TV y del mercado televisivo. 
El Tribunal Constitucional explicita la existencia del principio de acceso a la información pública como principio constitucional asegurado por el art. $8^{\circ}$ de la Constitución y regulado por la ley de Acceso a la Información Pública, cuyo artículo 10 reclamado, incluye a a TVN, dentro de las instituciones obligadas a la entrega de información, debiendo mantener como información pública, entre otras, la remuneración de sus gerentes. El Tribunal Constitucional determina que el acceso a la información pública forma parte también del derecho a la libertad de información contenida en el artículo 19 No 12 de la Constitución, constituyendo un mecanismo esencial para la plena vigencia del régimen democrático, de asunción de responsabilidades y de rendición de cuentas. Asimismo, el acceso a la información pública constituye un mecanismo que constituye un soporte básico para el adecuado ejercicio y defensa de los derechos fundamentales.

El Tribunal Constitucional en su considerando $14^{\circ}$ de la sentencia, precisa que la publicidad de la actuación de los gobernantes se encuentra íntimamente vinculada al régimen republicano democrático asegurado por el artículo $4^{\mathrm{o}}$ de la Constitución. Asimismo se apoya en la jurisprudencia de la Corte Interamericana de Derechos Humanos en el caso Claude Reyes y otros vs. Chile de 2006, párrafo 86, donde se precisa que Chile debe regirse por los principios de publicidad y transparencia en la gestión pública, lo que posibilita el control democrático de la gestión estatal, pudiendo indagar y cuestionar el adecuado cumplimiento de las funciones públicas. Además se cita la Carta Democrática Interamericana en su artículo $6^{\circ}$.

Respecto del respeto a la protección de la vida privada contenido en el art. 19 No 4 de la Constitución, protege contra las presiones o intromisiones indebidas en ella, como también lo determina el artículo 11 No 2 de la CADH. Por lo tanto, ella puede ser objeto de límite o restricciones legales, encontrándose fuera de la vida privada los actos que tienen repercusiones sobre la ordenación de la vida social o sobre derechos de terceros o intereses legítimos de la comunidad. Así el Tribunal Constitucional determina que el artículo 10 de la ley cuestionada posibilita que la ciudadanía conozca el uso de los recursos públicos en empresas públicas, lo que constituye una materia de interés público, por lo que la disposición legal analizada no es inconstitucional.

En este caso, el Tribunal Constitucional usa la jurisprudencia de la CIDH, como un argumento que respalda su propia decisión jurisdiccional, la que responde al seguimiento de principios determinados en un fallo de la $\mathrm{CIDH}$ 
respecto del caso chileno, desarrollando una interpretación receptiva de dicha jurisprudencia.

\subsection{El uso de la jurisprudencia de la CIDH en perspectiva de interpretación receptiva}

\subsubsection{El uso del postulado de interpretación pro homine o favor persona}

El Tribunal Constitucional chileno ha asumido en sus fallos a partir de 2008 el postulado de interpretación de derechos fundamentales aplicado por la Corte Interamericana de Derechos Humanos y contenido en el artículo 29 literal b) de la $\mathrm{CADH}$.

En el fallo Rol No 740-07, de 2008, el Tribunal Constitucional determinó:

"Que de todo lo expuesto sólo es posible concluir que la existencia de una norma reglamentaria que contiene disposiciones que pueden llevar a afectar la protección del derecho a la vida de la persona que está por nacer y que la Constitución buscó cautelar especialmente, la vulnera porque la sola duda razonable, reflejada en las posiciones encontradas de los expertos del mundo de la ciencia, de que la aplicación de esas normas reglamentarias pueda llegar a afectar el derecho a la vida del nasciturus, obliga al juez constitucional a aplicar el principio favor persona' o 'pro homine' en forma consecuente con el deber impuesto al Estado por la Carta Fundamental de estar al 'servicio de la persona humana' y de limitar el ejercicio de la soberanía en función del respeto irrestricto del derecho más esencial derivado de la propia naturaleza humana de la que el nasciturus participa en plenitud".

El uso del postulado o principio de interpretación de derechos fundamentales favor persona fue reiterada por el Tribunal Constitucional en la sentencia 136109, en su sentencia sobre la LEGE de 2009, donde se asume el postulado con el alcance precisado por la Corte Interamericana de Derechos Humanos, con cita explícita a ella: "Que, por otra parte, en el ejercicio de sus funciones, este Tribunal debe buscar aquella interpretación que se avenga mejor con el respeto de los derechos constitucionales. Así lo ha sostenido: "En tal sentido, parece ineludible tener presente el principio 'pro homine' o favor libertatis' definido en la jurisprudencia de la Corte Interamericana de Derechos Humanos de la siguiente forma: 'Entre diversas opciones se ha de escoger la que restringe en menor escala el derecho protegido (...) debe prevalecer la norma más favorable a la persona humana" (Opinión Consultiva 5, 1985);' (Rol 740);”. 
En sentencia Rol No 1484-09 de cinco de octubre de dos mil diez, el Tribunal Constitucional utiliza nuevamente el postulado de interpretación favor persona (pro homine) aplicándolo en materia de derechos fundamentales en su considerando $25^{\circ}$ : "Que, a mayor abundamiento, un juicio de constitucionalidad, como el que en esta oportunidad se realiza, no puede prescindir del hecho de que las normas que confieren derechos deben interpretarse de tal manera que potencien el goce del respectivo derecho y no al revés. Esta afirmación no es sino una consecuencia del clásico principio de interpretación favor homine o favor persona que obliga, precisamente, al intérprete normativo a buscar aquella interpretación que más favorezca los derechos de la persona antes que aquella que los anule o minimice. En palabras de Rubén Hernández Valle, "el citado principio, junto con el de pro libertatis, constituyen el meollo de la doctrina de los derechos humanos y significa que el derecho debe interpretarse y aplicarse siempre de la manera que más favorezca al ser humano". (Derechos fundamentales y jurisdicción constitucional. Grupo Editorial Kipus, Cochabamba, 2007, p. 48)".

En sentencia del Tribunal Constitucional Rol No 1881-10 de 3 de noviembre de 2011, sobre aplicabilidad del artículo 102 del Código Civil, el voto concurrente de los Ministros Carmona, Fernández Fredes, García y Viera Gallo, aplica el principio favor homine y favor libertatis, al referirse a las normas convencionales internacionales del PIDCP y la CADH sobre el derecho a contraer matrimonio: $\mathrm{Si}$ bien la Constitución no asegura explícitamente el derecho a contraer matrimonio sí lo hacen el Pacto Internacional de Derechos Civiles y Políticos de Naciones Unidas, en su artículo 23.2 y la Convención Americana sobre Derechos Humanos en su artículo 17.2.; lo que también asegura la Declaración Universal de Derechos Humanos en su artículo 16, los cuales reconocen el derecho a contraer matrimonio tanto a hombres como a mujeres, sin sostener que se reconoce el derecho sólo a hombres con mujeres, lo que queda entregado a la legislación interna de cada Estado, interpretando los derecho pro homine y pro libertatis, como se establece en el considerando $8^{\circ}$ del voto concurrente.

En estos casos, claramente el Tribunal Constitucional a través de los fallos considerados desarrolla un seguimiento de la jurisprudencia emanada de la Corte Interamericana de Derechos Humanos en su estándar de privilegiar la interpretación más favorable a los derechos de la persona humana, contenido en Opiniones consultivas y fallos contenciosos en que no se encuentra involucrado el Estado de Chile, lo que permite sostener que 
estamos en presencia de un diálogo que se concreta en perpectiva de una interpretación receptiva de la jurisprudencia de la Corte Interamericana de Derechos Humanos.

6.3. El uso por parte del Tribunal Constitucional de un diálogo con la CIDH en la perspectiva de una interpretación innovadora: El caso del derecho a la identidad personal extraido del derecho internacional de los derechos humanos ratificado y vigente, el que es utilizado como parámetro de control de constitucionalidad para determinar inconstitucionalidad de preceptos legales (Rol No 834 de 2008 y Rol $N^{o} 1340$ de 2009); casos en que se invoca la prohibición de prisión por deudas (roles $N^{o}$ s. 519, 576 y 807 de 2007; Rol No 1249 de 2008)

\subsubsection{Casos en que el Tribunal Constitucional asume el derecho a la identidad} personal extraido del derecho internacional de los derechos humanos ratificado y vigente, el que es utilizado como parámetro de control de constitucionalidad para determinar inconstitucionalidad de preceptos legales (roles $N^{o}$ s. 519, 576 y 807 de 2007; Rol No 1249 de 2008)

En el caso Rol No 834 de 2008, el requerimiento solicita que se declaren inaplicables los artículos 188, 199 y 199 bis del Código Civil, cuyo texto actual fue fijado por el artículo $1^{\circ}$ de la Ley $N^{\circ} 20.030$, publicada en el Diario Oficial del día 3 de julio de 2005, por ser contrarios a los numerales $2^{\circ}$, inciso segundo, $3^{\circ}$, inciso quinto, y $4^{\circ}$, todos del artículo 19 de la Constitución Política. Dicha declaración se solicita respecto del juicio ordinario caratulado "Magri con Magri”, RIT No C-680-2007, RUC 07-2-0098411-5, del que conoce actualmente el Cuarto Juzgado de Familia de Santiago, en el que se investiga la paternidad de su representado por demanda interpuesta en su contra por doña Susana Magri Vásquez.

En este caso, el Tribunal Constitucional rechazará la pretensión de inaplicabilidad por inconstitucionalidad de los preceptos señalados en el caso concreto, teniendo como elemento básico para adoptar tal posición el derecho a la identidad del menor, el cual no existe como derecho fundamental en el texto de la Constitución, el cual como derecho esencial constituye un fin legítimo, en virtud del cual se pueden establecer limitaciones o restricciones de otros bienes o derechos asegurados constitucionalmente. Para poder establecer esta perspectiva, necesariamente el Tribunal Constitucional debe partir del artículo $5^{\circ}$ inciso $2^{\circ}$ de la Constitución, que determina la limitación del ejercicio del poder 
público (soberanía) por el respeto de los derechos esenciales que emanan de la naturaleza humana, siendo deber de los órganos estatales respetar y promover tales derechos, ya sea que se encuentren asegurados en la Constitución, o en los tratados internacionales ratificados por Chile y vigentes. En este caso, el derecho a la identidad no se encuentra asegurado por la Carta Fundamental, por lo que, el Tribunal Constitucional tendrá que obtenerlo del derecho internacional de los derechos humanos, debiendo extraerlo interpretativamente de las disposiciones de tres convenciones o pactos internacionales, ellos son la Convención sobre Derechos del Niño, el Pacto Internacional de Derechos Civiles y Políticos y la Convención Americana sobre Derechos Humanos, como se determina en los considerandos 15 y $22^{\circ}$ :

"Decimoquinto: “(...) El derecho a la identidad personal comprende -en un sentido amplio- la posibilidad de que todo ser humano sea uno mismo y no otro y, en un sentido restringido, el derecho de la persona a ser inscrita inmediatamente después de su nacimiento, a tener un nombre desde que nace y, en la medida de lo posible, a conocer a sus padres y a ser cuidado por ellos. Desde este punto de vista existe una estrecha vinculación entre el derecho a la identidad personal y la dignidad humana -piedra angular de todo el edificio de los derechos fundamentales-, pues ésta sólo se afirma cuando la persona goza de la seguridad de conocer su origen y, sobre esa base, puede aspirar a ser reconocida como tal dentro de la sociedad;"

(...)

"Vigésimo Segundo: Que los antecedentes recordados no sólo dan cuenta de que los preceptos legales impugnados en esta litis no han pretendido discriminar en el ejercicio de las acciones de filiación ante los tribunales de justicia sino que, por el contrario, su propósito ha obedecido a la idea de corregir las distorsiones que dificultaban el debido acceso a la justicia en un ámbito que, como se ha expresado, tiene que ver con la plena protección de un derecho ligado estrechamente al valor de la dignidad humana, cual es el derecho a la identidad personal. Sobre el particular, ha de tenerse presente que aun cuando la Constitución chilena no lo reconozca expresamente en su texto, ello no puede constituir un obstáculo para que el juez constitucional le brinde adecuada protección. Lo anterior, precisamente, por su estrecha vinculación con la dignidad humana y porque tampoco puede desconocerse que él sí se encuentra protegido expresamente en diversos tratados internacionales ratificados por Chile y vigentes en nuestro país, como la Convención sobre los Derechos del Niño (artículo 7o), el Pacto Internacional de Derechos Civiles y Políticos (artículo 24.2) y la Convención Americana de Derechos Humanos (artículo 18). 
Por su parte, no apreciándose discriminación en la aplicación de las normas que se impugnan en estos autos, carece de sentido entrar a examinar, en esta sentencia, su razonabilidad y objetividad en conexión con el respeto a la igualdad ante la ley;".

La sentencia Rol No 1340 de 2009, se inicia por el requerimiento del Juez Presidente del Juzgado de Familia de Pudahuel, expone que en la causa RIT No C-111-2009, seguida por investigación/reclamación de paternidad, caratulada "Muñoz con Muñoz", se ha ordenado oficiar a esta Magistratura Constitucional para que se pronuncie sobre la inaplicabilidad del artículo 206 del Código Civil, por ser contrario a la Ley Fundamental, por eventual privación del derecho a la identidad asegurado por diversos instrumentos internacionales.

El Tribunal Constitucional se hace cargo de la infracción de la disposición legal cuestionada del artículo $5^{\circ}$, inciso segundo, de la Constitución Política, en la medida que dicha norma constitucional exige a los órganos estatales respetar y promover los derechos esenciales asegurados en el texto constitucional o en los tratados internacionales que contengan derechos esenciales de la persona humana, los cuales constituyen un límite al ejercicio de la soberanía.

El Tribunal Constitucional asume el derecho a la identidad como parte del parámetro de control para decidir si hay o no inconstitucionalidad en el caso concreto, el cual se encuentra asegurado por tratados internacionales ratificados y vigentes, en el considerando octavo de la sentencia:

"Que, en lo que atañe al derecho a la identidad personal, el requerimiento consigna dos órdenes de argumentaciones:

a) Que diversos tratados internacionales de aquellos que Chile ha ratificado y que se encuentran vigentes, consagran este derecho. Éste es el caso de la Convención Americana de Derechos Humanos que prescribe que: 'Toda persona tiene derecho a un nombre propio y a los apellidos de sus padres o al de uno de ellos. La ley reglamentará la forma de asegurar este derecho para todos, mediante nombres supuestos si fuere necesario' (artículo 18).

El Pacto Internacional de Derechos Civiles y Políticos precisa, por su parte, que 'todo niño será inscrito inmediatamente después de su nacimiento y deberá tener un nombre' (artículo 24.2).

A su turno, la Convención sobre los Derechos del Niño dispone que: 'El niño será inscrito inmediatamente después de su nacimiento y tendrá derecho desde que nace a un nombre, a adquirir una nacionalidad $y$, en la medida de lo posible, a conocer a sus padres y a ser cuidado por ellos. Los Estados Partes velarán por la aplicación 
de estos derechos de conformidad con su legislación nacional y las obligaciones que hayan contraído en virtud de los instrumentos internacionales pertinentes en esta esfera (...)' (artículo 7, numerales 1 y 2)”.

Además, el Tribunal Constitucional precisa, vía interpretativa de disposiciones de tres tratados internacionales, la existencia de un derecho a la identidad, de acuerdo con el segundo razonamiento realizado por el tribunal solicitante de la declaración de inconstitucionalidad del art. 206 del Código Civil, en el literal b del mismo considerando $8^{\circ}$ de la sentencia:

"Que de las referidas normas internacionales, unidas a doctrina autorizada que cita, se infiere que "la identidad queda comprendido (sic) en la categoría de 'los derechos esenciales que emanan de la naturaleza humana' como reza el artículo $5^{\circ}$ de la Constitución Política de la República, toda vez que atañe intrínsecamente a su propia individualidad tanto personalmente como en su dimensión social, sobrepasando el ámbito inicialmente resguardado referido a los derechos del niño para entender que beneficia a toda persona en su condición de tal".

El Tribunal Constitucional en el considerando noveno de la sentencia asume la existencia de este derecho esencial de la persona humana a la identidad, asegurado por diversos instrumentos del derecho convencional internacional, por lo cual existe la obligación del Tribunal Constitucional, como órgano del Estado, de respetarlos y promoverlos, como lo exige el artículo $5^{\circ}$, inciso $2^{\circ}$ de la Constitución:

"Que debe reconocerse, en efecto, que los diversos instrumentos internacionales, ratificados por Chile y vigentes, que cita el juez requirente en apoyo de su argumentación, consagran el derecho a la identidad personal generando, por ende, la obligación de los órganos del Estado de respetarlos y promoverlos, en los términos aludidos en el inciso segundo del artículo $5^{\circ}$ de la Carta Fundamental.

La afirmación precedente se concilia perfectamente con el criterio sostenido por esta Magistratura en el sentido de que el derecho a la identidad personal está estrechamente ligado a la dignidad humana, en cuanto valor que, a partir de su consagración en el artículo $1^{\circ}$, inciso primero, de la Ley Suprema, constituye la piedra angular de todos los derechos fundamentales que la Ley Suprema consagra. Asimismo, que aun cuando la Constitución chilena no reconozca, en su texto, el derecho a la identidad, ello no puede constituir un obstáculo para que el juez constitucional le brinde adecuada protección, precisamente por su estrecha vinculación con la dignidad humana y porque se encuentra protegido expresamente en diversos tratados internacionales ratificados por Chile y vigentes en nuestro país (Sentencia Rol No 834, considerando 22\%); 
En el considerando $10^{\circ}$ de la sentencia el Tribunal Constitucional analiza algunos atributos que integran el derecho a la identidad, como asimismo determina que todos los individuos poseen tal derecho, independientemente de su edad, anclando tal derecho en la dignidad de todo ser humano. Asimismo, el Tribunal Constitucional en el mismo considerando $10^{\circ}$ reconoce que la Constitución no constituye un sistema hermético de derechos que tienen su fuente únicamente en el propio texto constitucional, sino que el texto por la norma de reenvío del artículo $5^{\circ}$ inciso $2^{\circ}$ de la Constitución, lleva a considerar como integrantes del sistema de derechos asegurados constitucionalmente a aquellos cuyos atributos y garantías se encuentran en las fuentes del derecho convencional internacional, los cuales constituyen límites al ejercicio de la soberanía, debiendo siempre ser respetados por todos los órganos estatales:

"Las consideraciones que preceden justifican, precisamente, incluir el derecho a la identidad personal entre aquellos derechos esenciales a la naturaleza humana a que alude el artículo $5^{\circ}$, inciso segundo, de la Constitución, y que se erigen como límite de la soberanía, debiendo los órganos del Estado respetarlos y promoverlos, ya sea que estén asegurados en la propia Carta Fundamental o en tratados internacionales ratificados por Chile y que se encuentren vigentes".

El Tribunal Constitucional, en sus considerandos $11^{\circ}$ y $15^{\circ}$, siguiendo su razonamiento, integra este derecho a la identidad asegurado por instrumentos convencionales internacionales al parámetro de control de constitucionalidad, en virtud del cual se enjuiciará la inaplicabilidad por inconstitucionalidad del artículo 206 del Código Civil.

En ambas sentencias analizadas en este párrafo, el Tribunal Constitucional asume como derecho esencial el derecho a la identidad que debe ser respetado y garantizado por las normas infraconstitucionales, constituyendo parte del parámetro de constitucionalidad con el cual se enjuicia a las leyes en su aplicación a los casos concretos. En este caso, los atributos del derecho se extraen vía interpretativa del derecho convencional internacional de derechos humanos.

\subsubsection{Algunos casos en que se considera y aplica la Convención Americana sobre} Derechos Humanos en su artículo $7 N^{\circ} 7$ y el artículo $11^{\circ}$ del Pacto Internacional de Derechos Civiles y Politicos de Naciones Unidas, normas que especificamente prohiben la prisión por deudas (roles Nos. 519, 576 y 807 de 2007; Rol No 1249 de 2008)

Como explicita el propio Tribunal Constitucional en su sentencia rol No 519 de 2007, en su relación del requerimiento de inaplicabilidad por inconstitu- 
cionalidad en contra de las normas contenidas en los artículos $3^{\circ}, 12$ y 14 de la Ley No 17.322, en relación con diversas causas seguidas ante el Séptimo Juzgado del Trabajo de Santiago, se precisa por parte de los requirentes que es inconstitucional que los representantes legales de una sociedad respondan personalmente o sean objeto de arresto, ya que es una obligación de la sociedad respecto al trabajador y no una obligación personal de tales representantes legales. Los requirentes señalan que las normas de la Constitución Política violentadas serían los artículos $1^{\circ} ; 3^{\circ} ; 5^{\circ} ; 19$ No 3 y No 7 . Indican también, que existen disposiciones precisas, tanto en el Pacto Internacional de Derechos Civiles y Políticos como en la Convención Americana sobre Derechos Humanos, que consagran la prohibición absoluta de la prisión por deudas, y dado que el artículo $5^{\circ}$, inciso segundo, de la Constitución les otorga rango constitucional o supra legal, debe entenderse que se aplican por sobre otro tipo de normas.

El Tribunal Constitucional asume como parte de los derechos de las personas aquel contemplado en las convenciones internacionales de derechos humanos aludidas por el requirente, argumentando que en el caso específico no nos encontramos en presencia de una prisión por deuda, como señala en su considerando $23^{\circ}$ :

“(...) Por tanto, como se explicará más adelante, y tal como lo consigna el informe de la Comisión de Trabajo y Previsión Social del Senado, con motivo de la modificación de la Ley No 17.322, 'es pertinente destacar que no estamos frente a un caso de prisión por deudas, toda vez que el empleador se apropia o distrae dinero de propiedad de un tercero, el trabajador, y por ello, como bien ha resuelto la Excma. Corte Suprema en fallo de fines del año pasado, no es aplicable el Pacto de San José de Costa Rica'";

El Tribunal Constitucional se detendrá extensamente en el análisis del por qué no se infringe el derecho contenido en los tratados internacionales que prohíben la prisión por deudas, por lo que no se darían las condiciones para estimarse infringidas dichas convenciones en lo referente a los atributos de aseguramiento de la libertad individual y la garantía de la prohibición de prisión por deudas, en los considerandos $25^{\circ}$ a $29^{\circ}$ :

"Vigésimo Quinto: Que por lo demás y a mayor abundamiento, contrariamente a lo sostenido por los requirentes, el precepto legal en cuestión se encuentra en armonía con los deberes impuestos al Estado en materia de derechos esenciales que emanan de la naturaleza humana, tal como lo ordena el artículo $5^{\circ}$, inciso segundo, de la Constitución Política de la República, particularmente respecto de diversos tratados internacionales que prohíben la denominada 'prisión por 
deudas'. En efecto, el artículo 11 del Pacto Internacional de Derechos Civiles y Políticos establece que 'nadie será encarcelado por el solo hecho de no poder cumplir una obligación contractual', esto es, una deuda emanada de un contrato puramente civil. Sobre el punto, la doctrina ha señalado que esto significa que la privación de libertad basada en el incumplimiento de obligaciones legales, sean de derecho privado o público, es aceptable. De modo que cuando un tribunal impone la privación de libertad para compeler al cumplimiento de una obligación legal ello no importa una vulneración de la prohibición de la prisión por deudas. (Manfred NowaK, U.N. Covenant on Civil and Political Rights. CCPR Commentary. N.P. Engel, Publisher. Kerl, Strasbourg, Arlington, 1993). De esta forma, se ha concluido que las obligaciones contractuales a que suelen aludir los pactos internacionales dicen más bien relación con obligaciones civiles emanadas típicamente del derecho privado, que de aquellas establecidas por la ley. (Sarah Joseph, Jenny Schultz \& Melissa Castan, The International Covenant on Civil and Political Rights. Cases, Materials and Commentary, Second Edition, 2004). En el mismo sentido, el Tribunal Constitucional español ha sentenciado que "sólo puede hablarse con propiedad de prisión por deudas cuando la insolvencia tiene su base en el incumplimiento de una obligación contractual" (STC de España Rol No 230/1991);

Vigésimo Sexto: Que, en armonía con lo anterior, la Declaración Americana de Derechos Humanos, antecedente directo del Pacto de San José de Costa Rica, en su artículo 25, inciso segundo, prohíbe la detención 'por incumplimiento de obligaciones de carácter netamente civil'. Precisamente por lo mismo, el Convenio Europeo para la Protección de los Derechos Humanos y las Libertades Fundamentales admite la posibilidad de la detención o privación de libertad en su artículo $5^{\circ}$ 'por desobediencia a una orden judicial o para asegurar el cumplimiento de una obligación establecida en la ley’;

Vigésimo Séptimo: Que, como resulta claro, los más importantes tratados internacionales de derechos humanos, en concordancia con el mandato constitucional establecido en el artículo 19 No 7 de la Constitución, tuvieron especial preocupación por la libertad de las personas frente a los abusos en que pudiere incurrir el Estado mediante detenciones ilegales o arbitrarias, esto es, que no obedecieran al quebrantamiento de un mandato legal y a una causa debidamente justificada en la razón y la equidad. En esta misma línea, proscribieron la privación de la libertad por deudas, entendiendo por tales aquellas que tuvieran como antecedente el mero interés pecuniario de un individuo ('una obligación contractual' u 'obligaciones de carácter netamente civil'), de modo de no poner al servicio de causas únicamente particulares o privadas el aparato represivo del Estado. De este modo se ha aceptado la privación de libertad frente al grave incumplimiento de determinados deberes legales en la medida que estuviere envuelto el interés social y el buen funcionamiento de la comunidad, en otras palabras, el bien común, que 
constituye el fin que debe perseguir el Estado, tal como lo reconoce el artículo $1^{\circ}$ de nuestra Carta Fundamental;

Vigésimo Octavo: Que, adicionalmente, en concordancia con lo ya razonado, el numeral $7^{\circ}$ del artículo 7 de la Convención Americana de Derechos Humanos reitera que 'nadie será detenido por deudas. Este principio no limita los mandatos de autoridad judicial competente, dictados por incumplimientos de deberes alimentarios'. La discusión en torno al establecimiento de la disposición, en particular las observaciones de los países participantes en la Conferencia Especializada Interamericana sobre Derechos Humanos celebrada en San José de Costa Rica en noviembre de 1969, permite sostener que su finalidad se vincula con la proscripción de la privación de libertad derivada de deudas propiamente civiles y, en modo alguno, con el incumplimiento de las obligaciones legales que involucran intereses de toda la sociedad;

Vigésimo Noveno: Que, por último, en relación a este capítulo, no puede desconocerse que el deber legal que le asiste al empleador de enterar en las instituciones de previsión social los dineros que previamente ha descontado a sus trabajadores para tal propósito, tiene cierta analogía o similitud con el cumplimiento de ciertos 'deberes alimentarios'. Dicha semejanza se observa al constatar que el arresto del empleador es consecuencia, en primer término, de la desobediencia de una orden judicial, como es el requerimiento de pagar las cotizaciones dentro de un determinado plazo. Además, como ya se ha razonado, ambas comparten ser una privación de libertad por deudas con fuente directa en la ley. A lo anterior debe agregarse que corresponde a un apremio con un claro interés social y público involucrado, toda vez que del pago de las respectivas cotizaciones pende en buena medida un correcto funcionamiento del sistema de seguridad social, que tiene como consecuencia asegurar pensiones dignas para los trabajadores del país, deber que además se impone especialmente al Estado supervigilar en el artículo 19 No 18 de la Constitución Política de la República;”.

En una perspectiva diferente, en sentencia rol No 576 de 2007, el Tribunal Constitucional acertadamente considera que, no se está en presencia de una prisión por deudas, sino que ante una apropiación indebida del empleador de dineros que son propiedad de los trabajadores, por lo cual no hay una vulneración de la Convención Americana de Derechos Humanos, aunque al realizar tal reconocimiento el Tribunal razona integrando el derecho a no ser objeto de prisión por deudas como parte del parámetro de control de constitucionalidad en forma tácita, como lo precisa en su considerando vigésimo tercero. Su argumentación se realiza tanto en torno a la Convención Americana de Derechos Humanos, como al Pacto Internacional de Derechos Civiles y Políticos de Naciones Unidas. 
El Tribunal Constitucional abunda en razonamientos del porqué la norma legal chilena no vulnera las obligaciones en materia de respeto y promoción de derechos humanos contenidos en la Convención Americana de Derechos Humanos y al Pacto Internacional de Derechos Civiles y Políticos, a la cual reenvía el art. $5^{\circ}$ inciso $2^{\circ}$ de la Constitución, como reflexiona el Tribunal en su considerando vigésimo quinto, repitiendo el considerando $25^{\circ}$ del Rol No 519 , y agregando en el considerando $26^{\circ}$ :

"Que en armonía con lo anterior, la Declaración Americana de Derechos Humanos, antecedente directo del Pacto de San José de Costa Rica, en su artículo 25, inciso segundo, prohíbe ser detenido "por incumplimiento de obligaciones de carácter netamente civil". Precisamente por lo mismo, el Convenio Europeo para la Protección de los Derechos Humanos y las Libertades Fundamentales admite la posibilidad de la detención o privación de libertad "por desobediencia a una orden judicial o para asegurar el cumplimiento de una obligación establecida en la ley;”.

Luego de desentrañar los contenidos de dicho derecho en el ámbito de los tratados internacionales de derechos humanos vinculantes para el Estado Chileno, el Tribunal Constitucional determina que existe una armonía entre dichas obligaciones de respeto y promoción de los derechos esenciales contenidos en ellos y el mandato constitucional del artículo 19 No 7 de la Carta Fundamental, como lo explicita en su considerando vigésimo séptimo, repitiendo el considerando del fallo No 519, considerando $27^{\circ}$, ya reproducido.

El Tribunal Constitucional concluirá su razonamiento sobre la materia haciendo una analogía respecto del contenido del artículo 7 No 7 de la Convención Americana, que autoriza a los tribunales a determinar la privación de libertad de personas por incumplimiento de deberes alimentarios a la privación de libertad por incumplimiento de deberes en materia de enterar cotizaciones pertenecientes a los trabajadores por parte de su empleadores a las instituciones provisionales, lo que realiza en el considerando vigésimo octavo:

"Que, adicionalmente, en concordancia con lo ya razonado, el numeral $7^{\circ}$ del artículo 7 de la Convención Americana de Derechos Humanos reitera que "nadie será detenido por deudas. Este principio no limita los mandatos de autoridad judicial competente, dictados por incumplimientos de deberes alimentarios". La discusión en torno al establecimiento de la disposición, en particular las observaciones de los países miembros, permite sostener que su finalidad se vincula con la proscripción de la privación de libertad derivada de deudas propiamente civiles $y$, en modo alguno, al incumplimiento de las obligaciones legales que involucran intereses de toda la sociedad;". 
En la sentencia rol No 807 de 2007, el Tribunal Constitucional debe pronunciarse sobre el cuestionamiento de la ley No 18.216, en virtud del derecho a no ser objeto de prisión por deudas, el Tribunal Constitucional asume que "para acoger la acción interpuesta resultaría necesario que se verificara una doble condición: en primer lugar, que existiera contradicción entre el artículo 19 de la Ley $N^{o} 18.216$-o más precisamente entre los efectos que produciría la aplicación de ese precepto en la gestión pendiente- y alguna de las normas de derecho internacional invocadas, y que, además, y en segundo lugar, en virtud de lo establecido en el artículo 50, inciso segundo, de la Carta Fundamental, tal contradicción habilitara a esta Magistratura para declarar inaplicable el precepto legal".

El Tribunal Constitucional asume como parámetro de control los derechos asegurados convencionalmente en la Convención Americana sobre Derechos Humanos y en el Pacto Internacional de Derechos Civiles y Políticos, en los considerandos undécimo y decimotercero:

"Que el artículo 7.7 del Pacto de San José de Costa Rica prescribe: "Nadie será detenido por deudas. Este principio no limita los mandatos de autoridad judicial competente dictados por incumplimientos de deberes alimentarios". Por su parte, el artículo 11 del Pacto Internacional de Derechos Civiles y Políticos dispone: "Nadie será encarcelado por el solo hecho de no poder cumplir una obligación contractual".

"Que, como puede apreciarse, las normas de derecho internacional que se invocan como infringidas no son idénticas y la primera es más comprensiva que la segunda, en cuanto esta última sólo prohibe el encarcelamiento por obligaciones contraídas en virtud de un contrato, como expresa inequivocamente su texto. Esta sola restricción es suficiente para desestimar la contradicción alegada a su respecto, pues la deuda que se presenta como causal de indebido encarcelamiento no proviene de un contrato, sino de una sentencia judicial. En consecuencia, y en lo que sigue, se continuará el análisis de la eventual contradicción con la norma contenida en el Pacto de San José de Costa Rica, ya transcrita.

"De la sola lectura del texto de la norma del Pacto de San José transcrita fluye inequivoco su sentido: prohibir que una persona pueda sufrir privación de libertad como consecuencia del no pago de una deuda. Lo prohibido es que la conducta de no pagar una obligación pecuniaria sea tratada jurídicamente como causa de una sanción privativa de libertad".

Luego el Tribunal determina que la ley no ha dispuesto que se encarcele a una persona por no pagar una deuda, sino que ha establecido una condición para que una persona condenada por un delito pueda concedérsele o mantener el goce del beneficio de cierta libertad cumpliendo los requisitos establecidos legalmente, el Tribunal determinará que "es el pago de la indemnización civil 
derivada de los daños del delito, pues el incumplimiento de ese pago no es causa de la privación de libertad, sino el delito que lo antecede".

El Tribunal Constitucional agrega en el considerando $16^{\circ}$ que:

"el pago de la indemnización es una condición del beneficio de la libertad vigilada y no la causa de la privación de libertad, no sólo fluye del sentido de los términos contenidos en esos preceptos ya transcritos, sino además y sobre todo de la naturaleza de la institución de la libertad vigilada, que es un beneficio alternativo a la cárcel, destinado a favorecer la reinserción y rehabilitación de las personas que han delinquido, sujeta a ciertas condiciones, cuya no verificación inicial o cuyo incumplimiento posterior no causa la cárcel, ya que ella es efecto del delito, sino que impide o revoca el beneficio".

En la sentencia Rol No 1249-2008, el requirente plantea la inaplicabilidad por inconstitucionalidad del art. 5, literal d) de la Ley No 18.216, en causa criminal por lesiones, por contravenir la prohibición de prisión por deudas contenida en el art. 7.7 de la Convención Americana sobre Derechos Humanos, el Tribunal Constitucional reitera las consideraciones ya formuladas en el fallo Rol No 807, de 4 de octubre de 2007, concluyendo que en el caso específico "este Tribunal decidirá que no concurre en la especie el presupuesto constitucional consistente en que 'la impugnación esté fundada razonablemente', por lo que el requerimiento de fojas uno debe ser declarado inadmisible".

\subsubsection{El requerimiento de inaplicabilidad Rol No 1683-10}

de 4 de enero de 2011 respecto del artículo 365 del Código Penal. Una posible interpretación del principio de protección del interés superior del menor, no discriminación de género, protección vida privada y libre desarrollo de la personalidad asegurados convencionalmente

El requirente considera que la penalización por el artículo 365 del Código Penal que sanciona el acceso carnal entre varones, donde uno de ellos es mayor de 14 y menor de 18 años, constituye una vulneración del derecho a la dignidad, igualdad ante la ley y prohibición de discriminación arbitraria, la libertad, el derecho a la vida privada y a la intimidad y el contenido esencial de los derechos, consagrados en los artículos $1^{\circ}$, inciso primero, y 19 No 2, 4, 7 y 26 de la Carta Fundamental y los arts 1.1. y 24 de la CADH; 2.1 y 3 del PIDCP y $7^{\circ}$ de la DUDH, estos últimos en relación en el artículo $5^{\circ}$ inciso $2^{\circ}$ de la Constitución. 
El fallo alude a la Corte Interamericana de Derechos Humanos, la que ha considerado que el interés superior del niño justifica la necesidad que le sea dada una protección especial, en vista de su falta de madurez física y mental, debilidad o inexperiencia, en su Opinión Consultiva 17/02 de 28 de agosto de 2002, como lo afirma el Tribunal Constitucional en su considerando $28^{\circ}$, tal cita le permite un respaldo de autoridad para sostener la razonabilidad basada en el interés superior del menor y su especial protección de la disposición del artículo 365 del Código Penal, sosteniendo así la ausencia de discriminación arbitraria en el caso analizado.

A su vez el voto de minoría de tres ministros argumenta como parte de sus consideraciones sobre la vulneración del derecho de no discriminación por consideraciones de género, de afectación del derecho a la privacidad y al libre desarrollo de la personalidad, los estándares sostenidos por el Tribunal Europeo de Derechos Humanos, el que sancionó a Inglaterra por penalizar conductas homosexuales consentidas entre adultos donde uno era menor de 21 años. (Dudgeon vs. United Kindom) en 1986 el TEDH condena a Irlanda por penalizar la sodomia (Norris vs. Irlanda, 1987); en 1993, reiteró los argumentos al condenar a Chipre (Modinos vs. Chipre, 1993). Finalmente, en 2003 condenó a Austria por tipificar como delitos conductas homosexuales entre personas mayores de 14 y menores de 18 (L.V.vs. Austria, 2003).

A ello se agrega la resolución del Comité de Derechos Humanos de Naciones Unidas, en 1992, que condenó a Australia por permitir que en Tasmania se castigaran relaciones homosexuales consentidas ( $C D H$, ONU, Toonen vs. Australia, 1992).

\subsection{Los casos en que el Tribunal Constitucional concreta una interpretación} neutralizadora de la jurisprudencia de la CIDH, sobre el derecho a la revisión de la sentencia penal (Art. 8, párrafo 2, literal h) de la CADH.

$$
\text { (Roles No } 986 \text { y No } 1130 \text { de 2008) }
$$

En dos casos considerados de 2008, puede sostenerse, sin duda alguna, que el Tribunal Constitucional no concreta el control de convencionalidad y una interpretación adecuada del derecho al recurso o revisión de la sentencia penal contemplado en el artículo 8.2 literal h) de la $\mathrm{CADH}$, conforme a la interpretación auténtica y final de la $\mathrm{CIDH}$; ni tampoco realiza el análisis pertinente en relación al artículo $14^{\circ}$, párrafo $5^{\circ}$ del PIDCP y la jurisprudencia 
del Comité de Derechos Humanos de Naciones Unidas ${ }^{75}$, existiendo en este último una abundante jurisprudencia.

En el caso Aarón Vásquez, Rol No 986, se analiza el derecho al recurso ante una sentencia penal, como parte del debido proceso ${ }^{76}$. La defensa del condenado plantea la acción de inaplicabilidad por inconstitucionalidad señalando que los efectos que genera el inciso $2^{\circ}$ del artículo 387 del Código Procesal Penal en el caso concreto, lo priva del derecho a la revisión de la sentencia a la que tiene derecho dentro de un debido proceso, el que se encuentra asegurado, además, por la norma de reenvío del artículo $5^{\circ}$ inciso $2^{\circ}$ en relación con los artículos $8^{\circ}$ párrafo 2 , literal h) de la CADH. y en el art. 14, párrafo 5 del PIDCP de NU.

Puede sostenerse que los estándares mínimos del derecho a la revisión del fallo penal o al recurso en el sistema interamericano quedan claramente explicitados en la jurisprudencia de la CIDH en el caso "Herrera Ulloa vs. Costa Rica", donde la CIDH determina detalladamente los requisitos que debe contemplar el derecho a la revisión de la sentencia penal para cumplir los parámetros determinados por la CADH en su art. 8.2. literal h):

a) Para que haya una verdadera revisión de la sentencia, en el sentido requerido por la Convención, es preciso que el tribunal superior reúna las características jurisdiccionales que lo legitiman para conocer del caso concreto (Párrafo $159^{\circ}$ ).

b) Se debe entender que el recurso que contempla el artículo 8.2.h. de dicho tratado debe ser un recurso ordinario eficaz mediante el cual un juez o tribunal superior procure la corrección de decisiones jurisdiccionales contrarias al derecho. (Párrafo $161^{\circ}$ ). La Corte ha establecido que "no basta con la existencia formal de los recursos sino que éstos deben ser eficaces", es decir, deben dar resultados o respuestas al fin para el cual fueron concebidos (párrafo $161^{\circ}$ ).

c) Si bien los Estados tienen un margen de apreciación para regular el ejercicio de ese recurso, no pueden establecer restricciones o requisitos que infrinjan la esencia misma del derecho de recurrir del fallo (párrafo $161^{\circ}$ ).

d) La posibilidad de "recurrir del fallo" debe ser accesible, sin requerir mayores complejidades que tornen ilusorio este derecho (párrafo $164^{\circ}$ ).

75 Dictamen de 20 de junio de 2000 (caso Gómez Vásquez c. España, 701/1996); Dictamen de 30 de julio de 2003 (en caso Joseph Semey c. España); Dictamen de 7 de agosto de 2003 (en caso Sineiro Fernández c. España, 1007/2001); Dictamen de 29 de marzo de 2005 (en caso Martínez Fernández c. España).

${ }^{76}$ Sentencia del Tribunal Constitucional, Rol No 986-2007, de 30 de enero de 2008. 
e) Independientemente de la denominación que se le dé al recurso existente para recurrir un fallo, lo importante es que dicho recurso garantice un examen integral de la decisión recurrida (párrafo $165^{\circ}$ ).

En el caso Aarón Vásquez, se niega el derecho al recurso en virtud de que éste ha sido condenado en dos sentencias, habiendo sido anulado el primer juicio en virtud de haber ejercido recurso de nulidad el Ministerio Público, siendo condenado el afectado en el segundo juicio a una pena mayor después de ser recalificado el delito por el segundo tribunal de homicidio simple a homicidio calificado. El artículo 387 inciso 2o del Código Procesal Penal niega al condenado en el segundo juicio el derecho al recurso cuando éste ya había sido condenado en el primer juicio, sin que este último nunca hubiere podido haber ejercido el derecho al recurso, lo que afecta en su esencia el derecho al recurso, lo que supera todo margen de apreciación que pueda dejarse al legislador nacional, como establece el párrafo 161 de la sentencia Herrera Ulloa vs. Costa Rica, lo que no es asumido por el Tribunal Constitucional que se queda con una interpretación de que Aarón Vásquez debió haber recurrido de la primera sentencia porque ella ya le había producido un agravio al condenarlo (considerando $15^{\circ}$ ), considerando que el condenado al no hacer uso del derecho al recurso contemplado en el ordenamiento jurídico, respecto de la primera sentencia, que le había causado un agravio objetivo, pese a no considerarlo así subjetivamente el condenado, no posibilitó al segundo tribunal ampliar su competencia específica, limitando por voluntad propia su derecho de defensa (considerando $22^{\circ}$ ), dicha perspectiva implica asumir una concepción restrictiva del derecho al recurso que es contraria a una interpretación favor persona y al principio pro accione que el Tribunal Constitucional ha sustentado en otras ocasiones, lo que cuestionará el voto disidente de la sentencia (Ministros Mario Fernández y Hernán Vodanovic).

Asimismo, sostiene la sentencia del Tribunal Constitucional que analizar las consideraciones de mérito que tuvo el legislador al asumir el sistema recursivo implementado por el Código Procesal Penal (considerando 16º), no es de competencia suya, lo que es efectivo, pero sí es competencia determinar si la norma legal que regula el sistema recursivo cumple con el estándar mínimo exigido constitucionalmente, considerando la norma de reenvío del art. 5० inciso $2^{\circ}$ al artículo $8^{\circ} .2$. literal h) de la $\mathrm{CADH}$, para lo cual necesariamente debe tenerse en consideración la interpretación de ella de la CIDH, como intérprete final de la Convención. 
No es efectivo que si se acogiere la acción de inaplicabilidad se estaría en el caso concreto dejando sin recurso igualmente a Aarón Vásquez, ya que no es necesario declarar inaplicable todo el texto del inciso $2^{\circ}$ del artículo 387 del CPP, sino sólo aquella parte que determina la inexistencia de recurso cuando hay segundo fallo condenatorio, vale decir, sólo la primera parte del inciso $2^{\circ}$ de la disposición considerada.

A su vez, el Tribunal Constitucional olvida en su considerando $38^{\circ}$ que el derecho al recurso es el derecho a un recurso ordinario eficaz como establece la $\mathrm{CIDH}$ en la sentencia Herrera Ulloa vs. Costa Rica en su párrafo $161^{\circ}$, por tanto es improcedente referirse como lo hace la sentencia del Tribunal Constitucional a los recursos de queja (545 Código Orgánico de Tribunales) y de revisión de sentencia firme (arts. 473 y ss. del CPP), ya que ellos son recursos extraordinarios que no cumplen el estándar mínimo de la $\mathrm{CADH}$.

Además, el derecho al recurso debe ser un recurso que garantice un examen integral de la decisión recurrida, como determina la CIDH en el caso Herrera Ulloa en su párrafo $165^{\circ}$, tema sobre el cual el Tribunal Constitucional no desliza reflexión jurídica alguna sobre la materia.

En suma, en este caso, la sentencia del Tribunal Constitucional omite considerar el estándar mínimo exigido por el derecho al recurso contenido en el art. $8^{\circ} .2$. literal h) de la $\mathrm{CADH}$, en la interpretación y aplicación hecha por la $\mathrm{CIDH}$, omitiendo el control de convencionalidad exigido por el sistema interamericano de protección de derechos a los jueces nacionales, entre ellos a los tribunales constitucionales.

La sentencia del Tribunal Constitucional en este caso omite concientemente realizar control de convencionalidad mediante una interpretación receptiva de la jurisprudencia de la CIDH en el caso Herrera Ulloa vs. Costa Rica, prefiriendo realizar una operación de interpretación neutralizadora que la deja expuesta a que su sentencia si llega a la Corte Interamericana de Derechos Humanos, la determine como causa de la responsabilidad internacional del Estado de Chile por violación del derecho a las garantías judiciales del artículo 8.2, literal $\mathrm{H}$, de la CADH.

Sólo será el voto disidente de los Ministros Fernández y Vodanovic el que se hará cargo del derecho al recurso asegurado por el derecho convencional internacional de derechos humanos vinculante y exigible al Estado chileno a través del PIDCP, la CADH y la Convención sobre Derechos del Niño, (considerando 23); que el agravio para Aarón Vásquez se produjo en la segunda sentencia condenatoria que calificó al delito como homicidio calificado y no en la primera 
(considerando 25\%), del estándar fijado por la CIDH en el caso Herrera Ulloa vs. Costa Rica, determinando que la disposición del Código Procesal Penal privaba a Aarón Vásquez del derecho al recurso, al impedirle recurrir cuando éste se consideraba agraviado por la sentencia del segundo juicio, como asimismo, recriminará a la mayoría del tribunal por no hacerse cargo de que el derecho al recurso es a un recurso ordinario eficaz y no a un recurso extraordinario como es la queja disciplinaria, o como es el recurso de revisión (considerando $26^{\circ}$ ).

El mismo tema vuelve a ser planteado en el caso Rol No $1130^{77}$, repitiéndose las argumentaciones en sus aspectos centrales, el fallo en su considerando $6^{\circ}$ repite las consideraciones ya formuladas en el fallo anteriormente analizado (Rol No 986), sobre las consideraciones y características del proceso penal acusatorio y del sistema recursivo implementado por el legislador; se precisa que se desecha la apelación y se opta por el recurso de nulidad (considerando $12^{\circ}$ ), luego analiza las causales del recurso de nulidad, para luego examinar los requisitos de la acción de inaplicabilidad, determinado que en este caso concreto, la parte no se refiere al tercer elemento del cotejo, las características del caso concreto y los efectos inconstitucionales que producirían el mismo la aplicación del artículo 383 inciso $2^{\circ}$, limitándose a contrastar la norma legal con la constitucional (considerando $18^{\circ}$ ); al no señalar la parte los efectos concretos inconstitucionales que produce la aplicación de la disposición cuestionada y la forma en que se produce, no puede darse lugar al requerimiento de inaplicabilidad por inconstitucionalidad (considerando $20^{\circ}$ ).

La disidencia de los ministros Jorge Correa y Hernán Vodanovic determina que la inaplicabilidad puede deducirse de la incompatibilidad absoluta del precepto legal con el parámetro de control de constitucionalidad, lo que lógicamente determina su inaplicabilidad al caso concreto (considerando $3^{\circ}$ ), que la pérdida de eficacia del inciso $2^{\circ}$ del artículo 383 del CPP, se evita declarando inaplicable sólo la primera parte del inciso cuestionado (considerando 4 ) ; por otra parte, "debe ponderarse el derecho de un imputado criminal a recurrir en contra de la sentencia que lo condena, garantía esencial de la libertad personal, misma que constituye componente indispensable para calificar a un procedimiento penal como justo y racional y para estimar asegurado el derecho a la defensa" (considerando 9º); asimismo, la privación del derecho al recurso en el caso concreto produce un efecto inconstitucional, al trasgredir el derecho constitucional a la igual protección de los derechos (considerando

77 Sentencia del Tribunal Constitucional, Rol No 1130-07-INA, de 7 de octubre de 2008. 
$12^{\circ}$ ); asimismo, no responde a los estándares fijados por el PIDCP y la $\mathrm{CADH}$, además de considerar que el derecho al recurso es a un recurso ordinario, lo que no cumple el recurso de queja (considerandos 16 y 17\%).

Cabe explicitar que el derecho a la revisión de la sentencia penal debe cumplir cabalmente con los estándares mínimos que contempla el artículo $8^{\circ}$ párrafo 2, literal h), de la $\mathrm{CADH}$, en la interpretación y aplicación hecha por el órgano final del mismo que es la CIDH. El no considerar tales estándares mínimos vulnera los deberes de respeto y garantía de los derechos fundamentales contenido en el artículo $1^{\circ}$ y la obligación contenida en el artículo $2^{\circ}$, de adoptar las medidas adecuadas, dentro de la respectiva competencia del órgano jurisdiccional que exige la $\mathrm{CADH}$, además de la violación específica del artículo 8.2. literal h) de la misma Convención.

\section{CONCLUSIONES}

El diálogo interjurisdiccional entre jueces nacionales y Corte Interamericana de Derechos Humanos con un cierto alcance vertical por la obligación de cumplir los fallos de la Corte Interamericana por el Estado juez chileno, no impide al juez nacional iniciar un diálogo ascendente con esta última, bajo las distintas modalidades analizadas.

El control de convencionalidad no es un concepto generado por la Corte Interamericana de Derechos Humanos, tal concepto es usado desde hace décadas en distintos sistemas en que los estados partes se han obligado a respetar y garantizar estándares mínimos de derechos contenidos en instrumentos internacionales que ellos han ratificado libre y voluntariamente, con el objeto de cumplir el objeto y fin de dichos tratados de derechos humanos.

El control de convencionalidad en el ámbito interamericano implica:

a) Todos los órganos del Estado Parte, incluidos los jueces de todos los niveles están obligados a velar porque los efectos de la Convención no se vean mermados por la aplicación de leyes contrarias a su objeto y fin, concretando un control de convencionalidad de las normas jurídicas internas.

b) Este control de convencionalidad deben realizarlo los jueces nacionales y los demás órganos estatales ex officio, otorgándole un efecto útil que no sea anulado por aplicación de leyes contrarias a objeto y fin.

c) En dicho control debe tenerse en consideración no sólo el tratado sino la interpretación que de éste ha realizado la Corte Interamericana como su intérprete auténtico y final. 
d) El control de convencionalidad se ejerce por cada órgano estatal y por los jueces dentro de sus respectivas competencias y las regulaciones procesales vigentes.

e) En base al control de convencionalidad es necesario que las interpretaciones judiciales y administrativas y las garantías judiciales se apliquen adecuándose a los principios establecidos por la Convención Americana de Derechos Humanos.

f) En el control de convencionalidad no se aplica sólo la Convención Americana sobre Derechos Humanos sino el corpus iuris vinculante para el Estado parte, en virtud del artículo 29 de la CADH.

El control de convencionalidad implica el empoderamiento de todos los jueces nacionales al ampliarle su perspectiva de aplicación de los estándares mínimos del corpus iuris interamericano exigibles conforme a la $\mathrm{CADH}$ interpretada por su intérprete final que es la $\mathrm{CIDH}$, situación absolutamente similar a la que ejercen los jueces internos de los estados europeos en relación a la Convención Europea de Derechos Humanos y la ratio decidendi de los fallos del TEDH, lo que posibilita a todo juez del fondo aplicar preferentemente el estándar convencional sobre derechos al estándar interno más bajo sobre la misma materia, lo que como hemos visto es facultad de los jueces del fondo como lo ha reconocido la jurisprudencia de nuestro Tribunal Constitucional.

Asimismo, debe distinguirse claramente el control de convencionalidad del control de constitucionalidad, el primero tiene como parámetro el corpus iuris de los derechos humanos ratificado y vigente para el Estado Parte, mientras que el control de constitucionalidad tiene como parámetro la Constitución y el bloque de derechos fundamentales, como ya lo aplica en diversas ocasiones el Tribunal Constitucional chileno, como hemos podido verificar en este artículo.

El control de convencionalidad lo puede ejercer todo juez ordinario, especial o constitucional, en el ámbito de sus competencias y de acuerdo a los procedimientos establecidos, sin excepciones, el control de constitucionalidad lo puede ejercer los órganos jurisdiccionales que tienen tal competencia atribuida por la Constitución y que deben ejercer conforme a sus atribuciones y procedimientos específicos.

El control de convencionalidad lo puede ejercer todo juez de oficio, en virtud del principio iura novit curia, ya que el derecho vigente se presume conocido $\mathrm{y}$ todo juez tiene el deber constitucional de respetar y promover los derechos 
esenciales o fundamentales, además de garantizarlos de acuerdo con la Constitución, obligación imperativa conforme al artículo $5^{\circ}$ inciso $2^{\circ}$ de ella.

El Estado Parte y todos sus órganos, incluido el Estado juez, deben asumir la ratio decidendi de los fallos de la $\mathrm{CIDH}$, en cuanto órgano jurisdiccional vinculante de acuerdo con los artículos 67 a 69 de la CADH y en cuanto intérprete auténtico y final de la CADH, de acuerdo con los artículos 62.3 y 64 de la CADH, todo ello, cumpliéndolos de buena fe y sin oponer obstáculos de derecho interno, como lo exige los principios de ius cogens positivados en artículos 26, 27 y 31 de la Convención de Viena sobre Derecho de los Tratados, existiendo también en aval de tal posición, razones de economía procesal y de dotar de efecto útil a las sentencias de la CIDH, lo que constituye también una práctica asimilada en el sistema europeo respecto de la ratio decidendi de los fallos del TEDH.

El control de convencionalidad empodera a los jueces nacionales y les posibilita aplicar preferentemente el estándar mínimo interamericano de protección de derechos en forma preferente a la legislación interna cuando esta última se encuentra por debajo de dicho estándar de protección, de acuerdo al principio pro homine o favor persona, contenido en el artículo 29 literal b) de la $\mathrm{CADH}$ y asumido por la jurisprudencia del Tribunal Constitucional chileno.

El Tribunal Constitucional ha asumido en su jurisprudencia, especialmente en su sentencia Rol No 804-07-INA, de 2007, que el tribunal del fondo puede aplicar preferentemente las normas convencionales a las normas legales cuando estas últimas entran en conflicto con los derechos contemplados en las primeras.

Las jurisdicciones nacionales pueden entablar distintos tipos de diálogo con la Corte Interamericana que pueden resumirse a través de las interpretaciones receptiva, innovadora, extensiva, correctiva, neutralizadora y discordante.

El Tribunal Constitucional en el periodo 2006-2011, emplea en forma tímida la jurisprudencia de la Corte Interamericana de Derechos Humanos, en el periodo analizado, el Tribunal Constitucional utiliza escasamente la jurisprudencia de la CIDH. Ella lo hace en la perspectiva de una interpretación receptiva para asumir el principio interpretativo favor persona; en una interpretación correctiva en virtud de sentencias de la CIDH que previamente han condenado al Estado chileno por vulneración de tales derechos respecto del estándar interamericano sobre libertad de expresión o como el de acceso a la información pública; en una interpretación innovadora en los casos que ha asumido el derecho a la identidad, o en los que se ha referido a la prohibición 
de prisión por deuda, o la posible interpretación del principio de protección del interés superior del menor, no discriminación de género, protección vida privada y libre desarrollo de la personalidad; nos encontramos también con casos en que el Tribunal Constitucional concreta una interpretación neutralizadora en materia del derecho a la revisión de la sentencia penal, tratando de argumentar sobre la compatibilidad de la norma nacional con el derecho a la revisión de la sentencia penal con la norma convencional del artículo 8.2 h) de la CADH y el artículo 14.2 del PIDCP de Naciones Unidas, sin considerar su discordancia con la jurisprudencia de la Corte Interamericana de Derechos Humanos en el caso Herrera Ulloa vs. Costa Rica, lo que en la práctica constituye un intento de aplicar un margen de apreciación sobre el alcance del derecho a la revisión de la sentencia penal que la Corte Interamericana no ha reconocido en la materia, generando un riesgo inminente de condena al Estado de Chile por parte de la Corte Interamericana de Derechos Humanos generando responsabilidad internacional por violación de derechos humanos, posición que es reprochada por los votos de los Ministros disidentes de dichas sentencias que asumen una interpretación receptiva de la jurisprudencia de la CIDH.

Puede señalarse también que el Tribunal Constitucional chileno en ocasiones realiza referencias cruzadas a la Convención Europea de Derechos Humanos y a la interpretación de ella desarrollada por el Tribunal Europeo de Derechos Humanos que es ajeno al derecho aplicable en Chile, la que si bien es marginal en la jurisprudencia de nuestro Tribunal Constitucional es interesante de constatar, la cual se utiliza como argumento de autoridad o como refuerzo de las conclusiones desarrolladas por el propio Tribunal Constitucional, como parte de lo que podría considerarse también interpretación receptiva libre por la ausencia de relación jurídica vinculante entre ambos tribunales.

\section{BiBLIOGRAFía}

ABRAMOVICH, Víctor. "De las violaciones masivas a los patrones estructurales: el nuevo enfoque y clásicas tensiones en el Sistema Interamericano de Derechos Humanos. Sur-Revista Internacional de Derechos Humanos. Vol 6 No 11, www.revistasur.org http://www.surjournal.org/esp/conteudos/getArtigo11. php?artigo $=11$, artigo_01.htm

Aguilar Cavallo, Gonzalo. (2012). "El control de convencionalidad y el rol del juez nacional como juez de derechos humanos", en Nogueira Alcalá, Humberto (Coord.). (2012). El diálogo transjudicial de los tribunales cons- 
titucionales entre si y con las cortes internacionales de derechos humanos. Ed. Librotecnia, Santiago, pp. 449-508.

Albanese, Susana (Coord). (2008). El control de convencionalidad. Buenos Aires, Ed. Ediar.

Amaya Villareal, Álvaro Francisco. (2005). "El principio pro homine: interpretación extensiva vs. el consentimiento del Estado", en Revista Colombiana de Derecho Internacional No 5, junio, Bogotá, Pontifica Universidad Javeriana. pp. 337-380.

BAZÁN, Víctor, (2010) "El derecho internacional en la jurisprudencia de la Corte Suprema de Justicia, con particular énfasis en materia de derechos humanos", en La Ley, Suplemento Extraordinario (75 Aniversario), Buenos Aires, Agosto de 2010, pp. 1-17.

Berger, Vincent. (2011). Jurisprudence de la Cour Européenne des Droits de l'Homme. 12 édition. Ed. Dalloz, Paris.

Bidart Campos, G., (2001), "Las Fuentes del Derecho Constitucional y el Principio Pro Homine”, publicado en Bidart Campos, G. y Gil Domínguez, A., (coords.). AA.VV., El Derecho Constitucional del Siglo XXI: Diagnóstico y Perspectivas. Buenos Aires, Editorial Ediar

Burgorgue-Larsen, Laurence. (2009). "De l'internationalisation du dialogue des juges. Missive doctrinale à l'attention de Bruno Genevois", in Le dialogue des juges. Mélanges en l'honneur du président Bruno Genevois, Dalloz, Paris, pp. 95-130 (traduit et publié en portugais : Prismas: Dir., Pol. Publ. e Mundial, Brasilia, Vol. 7, No 1, jan./jun. 2010, pp. 261-304).

Burgorgue-Larsen, Laurence. (2009). "Conclusions. Pour une coopération interrégionale renforcée", Clôture du congrès international sur Les Cours régionales des droits de l'homme. Pratiques juridictionnelles et politiques jurisprudentielles, 60ème anniversaire de la Déclaration Universelle Des Droits de L'homme, 20 décembre 2009.

BuRgORgue-LARSEN, Lauréense. (2009). "El sistema Interamericano de protección de los derechos humanos: entre clasicismo y creatividad", in A. Von Bogdandy, C. Landa Arroyo, M. Morales Antoniazzi (dir.), ¿Integración Suramericana a través del Derecho? Un análisis Interdisciplinario y Multifocal, Madrid, CEPC, pp. 241-260

CANIVET, GUY. "Las influences croisées entre jurisdictions nacionales et internationales". Cours judiciaires Suprêmes Francophones http://www.ahjucaf.org/ Les-influences-croisees-entre,7177.html consultada 25 mayo de 2012. 
Carozza, P.G. (1998). Uses and Misures of Comparative Law, in International Human Rights: Some Reflections on the jurisprudence of the European Court of Human Rights. Notre Dame Law Review No 73, pp. 12181219.

CostA, Jean-Paul. (2010). En alocución de inauguración del "Dialogue entre juges.2010". Cour Européenne des droits de l'homme. Conseil de L'Europe. Strasbourg, 2010.http://www.echr.coe.int/NR/rdonlyres/3F410EB0-49804562-98F1 B30641C337A5/0/DIALOGUE_2010_EN.pdf

Corstein, Geert (2010). “Dialogue entre juges.2010”. Cour Européenne des Droits de l'Homme. Conseil de L'Europe. Strasbourg, 2010. http://www. echr.coe.int/NR/rdonlyres/3F410EB0-4980-4562-98F1 B30641C337A5/0/ DIALOGUE_2010_EN.pdf

Cour Europeenne des Droits de L'homme. (2010) “Dialogue entre juges. 2010" Conseil de L'Europe, Strasbourg. http://www.echr.coe.int/NR/ rdonlyres/3F410EB0-4980-4562-98F1-B30641C337A5/0/DIALOGUE_2010_EN.pdf

De Bechillon, D. (1998). "De quelques incidentes du control de conventionnalité international des lois par le juge ordinaire", en RFDA.

De Bechillon, D. (2001). "Conflits de sentences entre les juges de la loi", Revista Pouvoirs No 96, Paris.

De Gouttes, R. (1994). "La Convention européenne des droits de l'homme et le juge national: vers une consolidation de la mission et du status du juge", in Sudre (dir.), Le Droit Français el la Convention Européenne des Droits de l'Homme. 1974-1992. Ed. N.P. Engel.

De Vergottini, Giuseppe. (2010). Oltre il dialogo tra le Corti, Giudice, diritti straniero, comparazione. Ed. Il Mulino, Bologna. Traducción española (2011) Mas allá del diálogo entre tribunales. Comparación y relación entre jurisdicciones, con prólogo de Javier García Roca. Cuadernos Civitas-Thomson Reuters, Editorial Aranzadi, Pamplona.

De Vergottini, Giuseppe. (2011) "Il dialogo tranasnazionale fra le corti", en Mezzetti, Luca y Andrea Morrone (Coord.) (2011). Lo strumento costituzionale dell'ordine pubblico europeo. G. Giappichelli Editarte, Torino. Pp. 71-86.

Dubois, Julien. (2007). "La neutralisation. Dialogue des juges et interprétation neutralisante". En VV.AA. (2007). Le dialogue des juges. Institut de Droit des Droits del L'Homme. Cahiers de L'IDEDH No 11. Université de Montpellier I. Faculté de Droit. Montpellier, pp. 72-95. 
Ferrer Mac-Gregor, Eduardo. voto concurrente en la sentencia de la CIDH, Caso Cabrera García y Montiel Flores Vs. México. Excepción Preliminar, Fondo, Reparaciones y Costas. Sentencia de 26 de noviembre de 2010. Serie C No 220.

Ferrer Mac-Gregor, Eduardo (Coord.) (2012). El control difuso de convencionalidad. Diálogo entre la Corte Interamericana de Derechos Humanos y los jueces nacionales. Ed. Fundación Universitaria de Derecho, Administración y Política. S.C. (FUNDAp). Querétaro.

García Morelos, Gumersindo. (2010). El control judicial difuso de convencionalidad de los derechos humanos por los tribunales ordinarios mexicanos. México D.F. Editorial Ubijus. 45 p.

GarCía RAmírez, Sergio (Coord.). (2001). La jurisprudencia de la Corte Interamericana de Derechos Humanos. México, D.F., UNAM - Corte Interamericana de Derechos Humanos.

García Roca, Javier; Nogueira, Humberto y Bustos, Rafael (2012). "La comunicación entre los sistemas regionales americano y europeo de protección colectiva de los derechos humanos: el diálogo jurisdiccional entre la Corte Interamericana y el Tribunal Europeo". En Diálogo entre los Sistemas Europeo e Interamericano de Derechos Humanos. Ed. Civitas Thomson Reuters. Madrid, 2012, pp. 65-107.

GarCía-SAYÁn, Diego. (2005). "Una Viva Interacción: Corte Interamericana y Tribunales Internos", en La Corte Interamericana de Derechos Humanos: Un Cuarto de Siglo: 1979-2004, San José, Corte Interamericana de Derechos Humanos, pp. 323-384.

Gambino, Silvio. (2011). "Carta Europea dei diritti, dinamiche interordinamentali e rappoorti fra corti” en Mezzetti, Luca y Andrea Morrone (Coord.) (2011). Lo strumento costituzionale dell'ordine pubblico europeo. G. Giappichelli Editore, Torino, pp. 139-181.

Hennebel, Ludovic (2007). Les références croisées entre les jurisdictions internationales des droits del l'homme, en Martens, Paul ; Hennebel, Ludovic y Allard, Jullie.(2007). Le dialogue des juges. Les cahiers de l'institut d'études sur la justice. Actes du colloque organisé le 28 avril 2006 a l'Université libre de Bruxelles. Ed. Bruylant, Bruxelles, pp. 31-76.

Hernández Valle, Rubén. (2011) "El control convencional en el ordenamiento jurídico costarricense”. En Eto Cruz, Gerardo (coord.) Horizontes contemporáneos del Derecho Procesal Constitucional: Liber Amicorum Néstor Pedro Sagüés. Tomo I, Lima, Editorial Adrus, pp. 917-933. 
Hitters, Juan Carlos. (2009). "Control de constitucionalidad y control de convencionalidad. Comparación”; en Revista Estudios Constitucionales, año 7 No 2. Centro de Estudios Constitucionales de Chile, Campus Santiago, Universidad de Talca, pp. 109-128.

KамРтO, Maurice (2003). "Les interactions des jurisprudences internationales et des jurisprudences nationales", en S.F.D.I. La jurisdiccionalisatión $d u$ droit international. Ed. Pedone, pp. 393-460.

Lambert-Abdelgawad, E. (2004). "La Cour Européenne au service du Comité des Ministres pour une meilleure exécution des arrêts 'pilote" RTDH, 2004, pp. 203-224.

Lichere, F.; Potviun-Solis, L. y Raynouard, A. (2004). Le dialogue entre les juges européens et nationaux: incantation ou réalité? Université de Metz. Coll. Droit et Justice $\mathrm{N}^{\circ} 54$. Ed. Bruylant, Bruxelles.

LoiAno, Adelina, (2008). "El marco conceptual del control de convencionalidad en algunos fallos de la Corte Suprema Argentina: "Arancibia Clavel", "Simón", "Mazzeo", en Albanese, Susana (coord.), (2008). El control de convencionalidad, Buenos Aires, Editorial Ediar.

Londoño LÁZARo, María Carmelina. (2010). "El principio de legalidad y el control de convencionalidad de las leyes: confluencias y perspectivas en el pensamiento de la Corte Interamericana de Derechos Humanos", en Boletín Mexicano de Derecho Comparado No 128. México D.F., UNAM, pp. 761-814.

LuCChetTi, Alberto (2008). "Los jueces y algunos caminos del control de convencionalidad"; en Albanese, Susana (Coord.). El control de convencionalidad. Buenos Aires, Ed. Ediar, pp. 131-162.

Martens, Paul (2007) "L'ébouche d'une culture commune des cours suprêmes ou constitutionnelles", en Martens, Paul; Hennebel, Ludovic y Allard, Jullie. (2007). Le dialogue des juges. Les cahiers de l'institut d'études sur la justice. Actes du colloque organisé le 28 avril 2006 a l'Université libre de Bruxelles. Ed. Bruylant, Bruxelles, pp. 9-30.

Marginaux, J.-P. (1998). "L'appréciation par la Cour de Strasbourg des efforts d'adaptation du droit français des écoutes téléphoniques aux exigences de l'article 8 de la Convention Européenne des droits de l'homme", notes sur CEDH, 24 août 1998, Lambert c/ France, en RTD Civ., 1998, p. 995.

Marguenaud, J.-P. (2000). “Requiem pour l'adage Ubilex non distinguit? La Cour Européenne des Droits de l'Homme pourfend les lois trop générales 
qui n'établissent pas de discriminations positives" RTD Civ. Chron. Notes sous CEDH, Grand Chambre, 6 avril 2000, Thlimmenos c/Grèce. RTD Civ.

Medina Quiroga, Cecilia. (2008), Las obligaciones de los Estados bajo a Convención Americana sobre Derechos Humanos, en III Curso especializado para funcionarios de Estado sobre utilización del Sistema Interamericano de Protección de Derechos Humanos. Materiales bibliográficos No 1, San José.

Madeleine, Colombine. (2007). "L'anticipation. Manifestation d'un dialogue "vrai" entre juge nacional et juge européen ? ", en VV.AA. (2007). Le dialogue des juges. Institut de Droit des Droits del L'Homme. Cahiers de L'IDEDH No 11 . Université de Montpellier I. Faculté de Droit. Montpellier, pp. 129-156.

Mezzetti, Luca y Morrone, Andrea (Coord.) (2011). Lo strumento costituzionale dell'ordine pubblico europeo. G. Giappichelli Editarte, Torino.

Morrone, Andrea (2011). "Sui rapporti tra norme della CEDU e ordinamento costituzionale”, en Mezzetti, Luca y Andrea Morrone (Coord.). (2011). Lo strumento costituzionale dell'ordine pubblico europeo. G. Giappichelli Editarte, Torino, pp. 189-203.

Nash Rojas, Claudio. (2012). "Control de convencionalidad. Precisiones conceptuales y desafíos a la luz de la jurisprudencia de a Corte Interamericana de Derechos Humanos. En Nogueira Alcalá, Humberto (Coord.). (2012). El diálogo transjudicial de los tribunales constitucionales entre si y con las cortes internacionales de derechos humanos. Ed. Librotecnia, Santiago, pp. $359-385$.

Nogueira Alcalá, Humberto (Coord.). (2012). El diálogo transjudicial de los tribunales constitucionales entre si y con las cortes internacionales de derechos humanos. Ed. Librotecnia, Santiago.

Nogueira Alcalá, Humberto. (2012). Los desafíos del control de convencionalidad del corpus iuris interamericano para los tribunales nacionales, en especial, para los tribunales constitucionales. En Nogueira Alcalá, Humberto (Coord.). (2012). El diálogo transjudicial de los tribunales constitucionales entre si y con las cortes internacionales de derechos humanos. Ed. Librotecnia, Santiago, pp. 259-358.

Nogueira Alcalá, Humberto. (2012). "El uso del derecho convencional internacional de los derechos humanos en la jurisprudencia del Tribunal Constitucional chileno en el período 2006-2010". En Revista Chilena de 
Derecho. Volumen 39 No 1, Facultad de Derecho, Pontificia Universidad Católica de Chile, pp. 149 - 187

Nogueira Alcalá, Humberto. (2006). "Los desafíos de la sentencia de la Corte Interamericana en el caso Almonacid Arellano”. Ius et Praxis, 2006, vol. 12, No 2, pp. 363-384. "Revista de Derecho", Universidad Católica del Uruguay, Ver también Revista de Derecho No 2, Montevideo, Universidad Católica del Uruguay, pp. 217 y ss.

Ost, F. y De Kerchove, F. (2002). De la pyramide au réseau? Pour une théorie dialectique du droit. Publication des Facultés Universitaires Saint-Louis, Bruxelles. 596 pp.

Pradel, Jean; Corstens, Geert y Vermeulen, Gert. (2009). Droit Penal Européen. $3^{\text {a }}$ edición, Ed. Dalloz, Paris.

PINTO, Mónica. (1997) “El principio pro homine”, en AA.VV. La aplicación de los tratados sobre derechos humanos por los tribunales locales. Editorial Del Puerto. Buenos Aires.

Queralt, Argelia. (2003) El Tribunal de Estrasburgo: una jurisdicción internacional para la protección de los derechos fundamentales. Ed. Tirant lo Blanch, Valencia.

Quinche Ramírez, Manuel Fernando. "El control de convencionalidad y el sistema colombiano", en Revista Iberoamericana de Derecho Procesal Constitucional $\mathrm{N}^{\circ} 12$, julio-diciembre de 2009, pp. 163-190.

Ridola, P. (2006). La giurisprudenza costituzionale e la comparazione, en Alpa, G (Dir.) IL giudice e l'uso delle sentenze estraniere. Modalitá e technique della comparazione giuridica. Ed Giuffrè, Milano.

Rodríguez, Marcos del Rosario. "Del control de constitucionalidad al control de convencionalidad: la consolidación de la supremacía de la Convención Americana”, en Intertemas, Volumen No 14, Revista Jurídica de Toledo de Presidente Prudente-SP. Facultades integradas Antônio Eufrasio de Toledo. pp. 8-17. Versão eletrônica da Revista Intertemas impressa - ISSN 15168158 intertemas.unitoledo.br/revista/index.php/INTERTEMAS

SAGÜÉs, Néstor Pedro. El "control de convencionalidad", en particular sobre las constituciones nacionales, en La Ley, Buenos Aires, Jueves 19 de febrero de 2009, pp. 1-3.

SAGÜÉs, Néstor Pedro. (2010). Obligaciones internacionales y control de convencionalidad. Revista Estudios Constitucionales año 8 No 1. Centro de Estudios Constitucionales de Chile, Campus Santiago, Universidad de Talca. 117-136. 
Slaughter, A-M. (1994). "A typology of transjudicial communication”, University of Richmond Law Review 29.

Sudre, F y otros. (2005). Les grands arrêts de la Cour Européenne des Droits del'Homme. Ed Thémis. París.

Sudre, Frédéric. (2003). Droit Europeén et International des droits de l'homme. Sexta edición. Ed. PUF, Paris. En 2011 hay 10 edición refundida y aumentada, PUF, Paris, 925 pp.

Sudre, Frédéric. (2004). "A propos du 'dialogue des juges' et du control de conventionalité, en Etudes en l'honneur de Jean-Claude Gautron. (2004). Les dynamiques du droit européen en début du siècle. Ed. A. Pedone, Paris.

Sudre, Frédéric (2007). Avant-Propos, en VV.AA. (2007). Le dialogue des juges. Institut de Droit des Droits del L'Homme. Cahiers de L'IDEDH No 11. Université de Montpellier I. Faculté de Droit. Montpellier, pp. 7-9.

SuXe, Hervé. (2007). "La dimension objective du "dialogue des juges ", en Cahiers de l'IDEDH $N^{\circ} 11$, Le dialogue des juges, Université de Montpellier I, pp. 158-191. Consultado en página web http://www.idedh.fr/IMG/ pdf_pdf_Cahiers_IDEDH_11.pdf el 12 de mayo de 2012.

SzYMCZAK, David. (2006). La convention Europeénne des droits de l'Homme et le juge constitutionnel nacional. Ed Bruylant, Bruxelles.

VV.AA. (2007). Le dialogue des juges. Actes du colloque organisé le 28 avril 2006 a l'Université Libre de Bruxelles. Ed. Bruylant, Bruxelles.

VV. AA. (2007). Le dialogue des juges. Institut de Droit des Droits del L'Homme. Cahiers de L'IDEDH No 11. Université de Montpellier I. Faculté de Droit. Montpellier http://www.idedh.fr/IMG/pdf_pdf_Cahiers_IDEDH_11. pdf

ZúNIGA, Francisco. (2012). "Control de convencionalidad y tribunales nacionales. Una aproximación crítica”. En Nogueira Alcalá, Humberto (Coord.). (2012). El diálogo transjudicial de los tribunales constitucionales entre sí y con las cortes internacionales de derechos humanos. Ed. Librotecnia, Santiago, pp. 387-447.

\section{Sentencias del Tribunal Constitucional chileno}

Sentencia del Tribunal Constitucional, Rol N 740-07, de dieciocho de abril de 2008

Sentencia del Tribunal Constitucional, Rol No 986-2007-INA, de 30 de enero de 2008. 
Sentencia del Tribunal Constitucional, Rol No 1130-07-INA, de 7 de octubre de 2008.

Sentencia del Tribunal Constitucional, Rol No 1361-09, de trece de mayo de 2009.

Sentencia del Tribunal Constitucional, Rol No 567-10, de 3 de junio de 2010.

Sentencia del Tribunal Constitucional, Rol No 1.484-09 de 5 de octubre de 2010.

Sentencia del Tribunal Constitucional, Rol 1683-10 de 4 de enero de 2011.

Sentencia del Tribunal Constitucional, Rol No 1723-10/1800-10 de 21 de junio de 2011.

Sentencia del Tribunal Constitucional, Rol No 1656-10 de $1^{\circ}$ de septiembre de 2011.

\section{Sentencias de la Corte Interamericana de Derechos Humanos}

Corte IDH. Caso Velásquez Rodríguez vs. Honduras. Fondo. Sentencia de 29 de julio de 1988. Serie C No 4.

Corte IDH. Caso Castillo Petruzzi y otros vs. Perú. Fondo, Reparaciones y Costas. Sentencia de 30 de mayo de 1999. Serie C No 52.

Corte IDH. Caso del Tribunal Constitucional vs. Perú, sentencia de 24 septiembre de 1999. (Competencia). Serie C No 55.

Corte IDH. Caso "La Última Tentación de Cristo" (Olmedo Bustos y otros) vs. Chile. Fondo, Reparaciones y Costas. Sentencia de 5 de febrero de 2001. Serie C No 73.

Corte IDH, Caso Villagrán Morales y otros (caso "niños de la calle") vs. Guatemala, Fondo. Sentencia de 19 de noviembre de 1999, serie C Nº 63.

Corte IDH. Caso Herrera Ulloa vs. Costa Rica. Excepciones Preliminares, Fondo, Reparaciones y Costas. Sentencia de 2 de julio de 2004. Serie C No 107.

Corte IDH. Caso Tibi vs. Ecuador. Excepciones Preliminares, Fondo, Reparaciones y Costas. Sentencia de 7 de septiembre de 2004. Serie C No 114.

Corte IDH. Caso Palamara Iribarne vs. Chile. Fondo, Reparaciones y Costas. Sentencia de 22 de noviembre de 2005. Serie C No 135.

Corte IDH. Caso de la Masacre de Pueblo Bello vs. Colombia. Fondo, Reparaciones y Costas. Sentencia de 31 de enero de 2006. Serie C No 140.

Corte IDH. Caso Ximenes Lopes vs. Brasil. Fondo, Reparaciones y Costas. Sentencia de 4 de julio de 2006. Serie C No 149. 
Corte IDH. Caso Claude Reyes y otros Vs. Chile. Fondo, Reparaciones y Costas. Sentencia de 19 de septiembre de 2006. Serie C No 151.

Corte IDH. Caso Almonacid Arellano y otros Vs. Chile. Excepciones Preliminares, Fondo, Reparaciones y Costas. Sentencia de 26 de septiembre de 2006. Serie C No 154.

Corte IDH. Caso Trabajadores Cesados del Congreso (Aguado Alfaro y otros) Vs. Perú. Excepciones Preliminares, Fondo, Reparaciones y Costas. Sentencia de 24 de noviembre de 2006. Serie C No 158.

Corte IDH. Caso La Cantuta Vs. Perú. Fondo, Reparaciones y Costas. Sentencia de 29 de noviembre de 2006. Serie C No 162.

Corte IDH. Caso Heliodoro Portugal vs. Panamá. Excepciones Preliminares, Fondo, Reparaciones y Costas. Sentencia de 12 de agosto de 2008, serie C No 186.

Corte IDH. Caso Rosendo Radilla Pacheco vs. Estados Unidos Mexicanos. Excepciones Preliminares, Fondo, Reparaciones y Costas. Sentencia de 23 de noviembre de 2009. Serie C No 209.

Corte IDH. Caso Manuel Cepeda Vargas vs. Colombia. Excepciones Preliminares, Fondo y Reparaciones. Sentencia de 26 de mayo de 2010. Serie C No 213.

Corte IDH. Caso Comunidad Indígena Xákmok Kásek vs. Paraguay. Fondo, Reparaciones y Costas. Sentencia de 24 de agosto de 2010. Serie C No 214.

Corte IDH. Caso Fernández Ortega y Otros vs. México. Excepción Preliminar, Fondo, Reparaciones y Costas. Sentencia de 30 de agosto de 2010. Serie C No 215.

Corte IDH. Caso Ibsen Cárdenas e Ibsen Peña Vs. Bolivia. Fondo, Reparaciones y Costas. Sentencia de 1 de septiembre de 2010 Serie C No 217.

Corte IDH. Caso Cabrera García y Montiel Flores vs. México. Excepciones Preliminares, Fondo, Reparaciones y Costas. Sentencia de 26 de noviembre de 2010.

Corte IDH. Caso Gelman Vs. Uruguay. Fondo y Reparaciones. Sentencia de 24 de febrero de 2011 Serie C No 221.

Corte IDH. Caso Chocrón Chocrón Vs. Venezuela. Excepción Preliminar, Fondo, Reparaciones y Costas. Sentencia de 1 de julio de 2011. Serie C No 227.

Corte IDH. Caso López Mendoza Vs. Venezuela. Fondo Reparaciones y Costas. Sentencia de 1 de septiembre de 2011 Serie C No 233. 
Sentencias Corte Interamericana en casos chilenos

Corte IDH. Caso "La Última Tentación de Cristo" (Olmedo Bustos y otros) Vs. Chile. Fondo, Reparaciones y Costas. Sentencia de 5 de febrero de 2001. Serie C No 73.

Corte IDH. Caso Palamara Iribarne Vs. Chile. Fondo, Reparaciones y Costas. Sentencia de 22 de noviembre de 2005. Serie C No 135; Corte IDH.

Corte IDH. Caso Almonacid Arellano y otros Vs. Chile. Excepciones Preliminares, Fondo, Reparaciones y Costas. Sentencia de 26 de septiembre de 2006. Serie C No 154.

Corte IDH. Caso Claude Reyes y otros Vs. Chile. Fondo, Reparaciones y Costas. Sentencia de 19 de septiembre de 2006. Serie C No 151.

Corte IDH. Caso Atala Riffo y Niñas Vs. Chile. Fondo, Reparaciones y Costas. Sentencia del 24 de febrero de 2012. Serie C No 239.

\section{Opiniones Consultivas de la Corte Interamericana}

Corte IDH. "Otros Tratados" Objeto de la Función Consultiva de la Corte (art. 64 Convención Americana sobre Derechos Humanos). Opinión Consultiva OC-1/82 del 24 de septiembre de 1982. Serie A No 1.

Corte IDH. El Efecto de las Reservas sobre la Entrada en Vigencia de la Convención Americana sobre Derechos Humanos. Opinión Consultiva OC-2/82 del 24 de septiembre de 1982. Serie A No 2.

Corte IDH. La Colegiación Obligatoria de Periodistas (Arts. 13 y 29 Convención Americana sobre Derechos Humanos). Opinión Consultiva OC-5/85 del 13 de noviembre de 1985. Serie A No 5.

Corte IDH. Responsabilidad Internacional por Expedición y Aplicación de Leyes Violatorias de la Convención (arts. 1 y 2 Convención Americana sobre Derechos Humanos). Opinión Consultiva OC-14/94 del 9 de diciembre de 1994. Serie A No 14.

Corte IDH. Condición Jurídica y Derechos de los Migrantes Indocumentados. Opinión Consultiva OC-18/03 del 17 de septiembre de 2003. Serie A No 18.

\section{Sentencias de la Corte Europea de Derechos Humanos}

TEDH, caso Ireland vs. United Kingdom case, Judgment of 18 January 1978, Series A No 25. 
TEDH, caso Loizidou c. Turquía, excepciones preliminares, 23 de marzo de 1995

TEDH, caso Soering Case, decision of 26 January 1989, Series A No 161.

TEDH, 29 de noviembre de 1991, Vermeire c/ Bélgique, A 214-C.

TEDH. 23 de marzo de 1995, Loizidou c/ Turquia. Exceptions préliminaires, Serie A No 310.

TEDH, Grand Chambre, 6 avril 2000, Thlimmenos c/Grèce.

TEDH, Gr. Ch., 22 de junio de 2004, Broniowski c/ Pologne, req. № 31443/96.

TEDH, 9 janvier 2003, S.L c/ Austriche, req 45303/99

TEDH, 30 de junio de 2005, Bosphurus Java Jollari Turizm ve Ticaret c/ Irlanda. Req. 45036/98.

TEDH, Gr. Ch, 29 marzo 2006, Apicella c/ Italia, req. No 64890/01.

TEDH. Gr. Ch., 19 junio 2006, Hutten-Czapska c/ Pologne, req. No 35014/97.

\section{Comité de Derechos Humanos de la ONU}

Gómez Vásquez c. España, 701/1996: Comité de derechos humanos de la ONU, Dictamen de 20 de junio de 2000.

Joseph Semey c. España, 986/2001: Comité de derechos humanos de la ONU, Dictamen de 30 de julio de 2003.

Sineiro Fernández c. España, 1007/2001: Comité de derechos humanos de la ONU, Dictamen de 7 de agosto de 2003.

Alba Cabriada c. España, 1101/2002: Comité de derechos humanos de la ONU, Dictamen de 1 de noviembre de 2004.

Martínez Fernández c. España, 1104/2002: Comité de derechos humanos de la ONU, Dictamen de 29 de marzo de 2005.

\section{Comisión de Venecia}

Avis No 209/2002, CDL-AD (2002) 34 de la Comisión de Venecia sobre las sentencias de la Corte Europea de Derechos de Hombre adoptada en la 53 sesión plenaria (13-14 de diciembre de 2002). 